I N T ER N ATIONAL MONETARY FUND

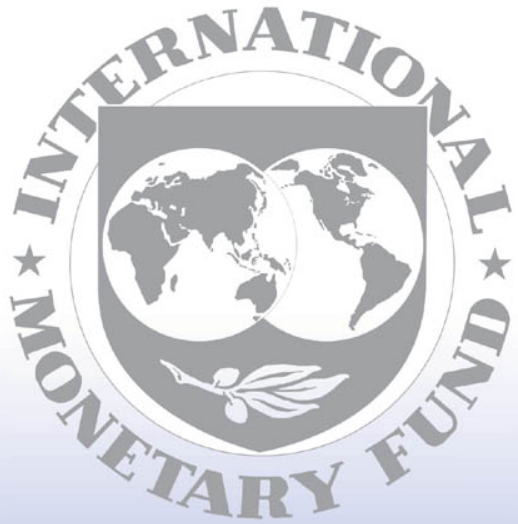

Staff

Country

Reports 


\title{
Romania - Sixth Review Under the Stand-By Arrangement, and Requests for Waiver of Nonobservance of Performance Criterion, and Request for Modification and Establishment of Performance Criteria_-Staff Report; Supplementary Information; Press Release on the Executive Board Discussion; Statement by the Executive Director and the Senior Advisor to the Executive Director for Romania
}

The following documents have been released and are included in this package:

- The staff report, prepared by a staff team of the IMF, following discussions that ended on November 1, 2010, with the officials of Romania on economic developments and policies. Based on information available at the time of these discussions, the staff report was completed on December 22, 2010. The views expressed in the staff report are those of the staff team and do not necessarily reflect the views of the Executive Board of the IMF.

- Supplementary information of January 05, 2011.

- Press Release summarizing the views of the Executive board as expressed during its January 07, 2011, discussion of the staff report that completed the review.

- A statement by the Executive Director and Advisor to the Executive Director for Romania

The documents listed below will be separately released.

- $\quad$ Letter of Intent sent to the IMF by the authorities of Romania*.

- $\quad$ Technical memorandum of Understanding*.

*Also included in Staff Report

The policy of publication of staff reports and other documents allows for the deletion of market-sensitive information.

Copies of this report are available to the public from

International Monetary Fund • Publication Services

700 19th Street, N.W. • Washington, D.C. 20431

Telephone: (202) 623-7430 • Telefax: (202) 623-7201

E-mail: publications@imf.org • Internet: http://www.imf.org

\author{
International Monetary Fund \\ Washington, D.C.
}




\title{
INTERNATIONAL MONETARY FUND
}

\section{ROMANIA}

\section{Sixth Review Under the Stand-By Arrangement, Request for Waiver of Nonobservance of Performance Criterion, and Request for Waiver of Applicability}

\author{
Prepared by the European Department \\ (In Consultation with Other Departments)
}

Approved by Poul M. Thomsen and Aasim Husain

December 22, 2010

\begin{abstract}
Program status: The performance criteria for end-September 2010 have been met, with the exception of the criterion on general government arrears, which will also be missed for end-December. Inflation remained within the inner band of the inflation consultation mechanism through end-November. Information on two of the four quantitative performance criteria for end-December 2010 and on the inflation target is unavailable and the authorities are requesting a waiver of applicability. Approval of the 2011 budget, approval of the revised unified wage law, enactment of the pension reform, and modification of an ordinance on bank lending, and maintenance of nearzero central government arrears are prior actions for this review.
\end{abstract}

Key issues: The review focused on three issues: (i) measures in the 2011 budget to assure compliance with fiscal targets; (ii) progress on the structural reform agenda; and (iii) efforts to ensure continued financial sector stability.

Discussions: Discussions were held in Bucharest, October 20-November 1, 2010. The mission met with President Basescu, Prime Minister Boc, Finance Minister Ialomiţianu, Central Bank Governor Isarescu, other senior officials, and representatives of labor and business organizations, and financial institutions. The staff team comprised J. Franks (head), A. Cebotari, M. Stierle, and L. Zhang (all EUR); F. Salman (SPR); F. Hasanov (FAD); and M. Dobler (MCM). T. Lybek (Resident Representative) assisted the mission. Discussions were held jointly with staff from the European Commission, the ECB, and the World Bank.

Stand-By Arrangement: A 24 month, SDR 11.443 billion ( $€ 12.95$ billion, US $\$ 17.07$ billion, $1,110.77$ percent of quota) Stand-By Arrangement was approved by the Executive Board on May 4, 2009 (Country Report No.09/183), and five purchases totaling SDR 9.800 billion have been made so far. The European Commission and the World Bank are also providing funds under the program. The seventh tranche of SDR 769 million will be made available subject to the completion of this review. 


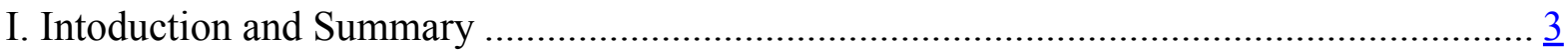

II. Macroeconomic Developments and Outlook ………….................................................. 4

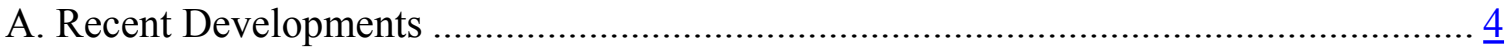

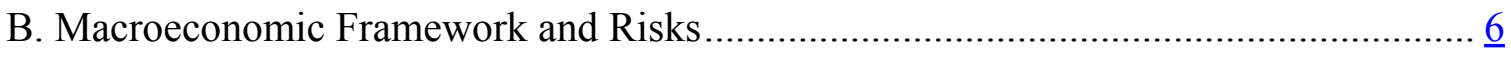

III. Policy Discussions ...........................................................................................

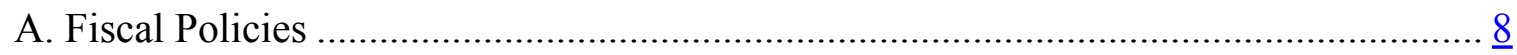

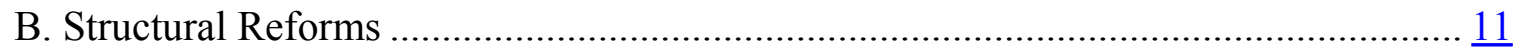

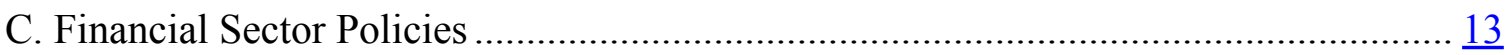

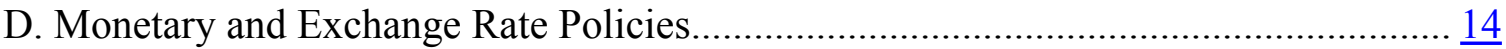

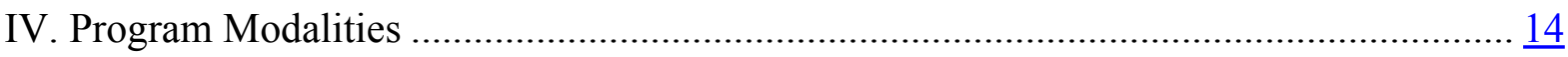

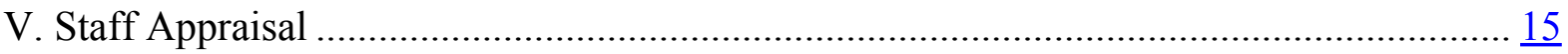

Box

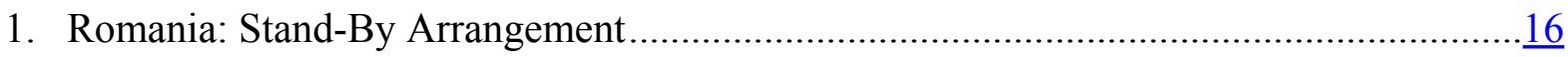

Figures

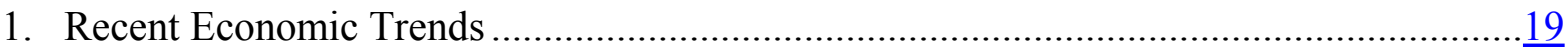

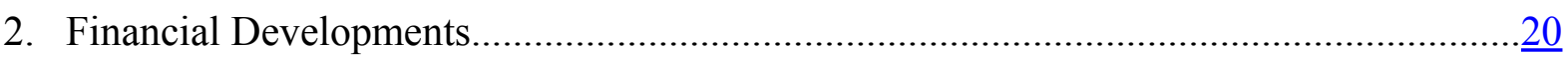

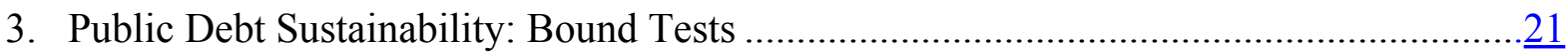

4. External Debt Sustainability: Bound Tests ...................................................................

Tables

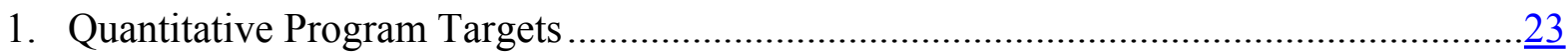

2. Performance for Sixth Review and Proposed New Conditionality ....................................

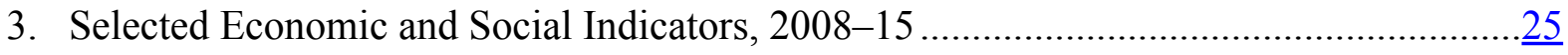

4. Balance of Payments, 2008-15 ...............................................................................

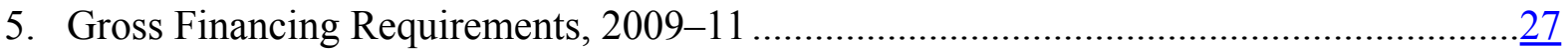

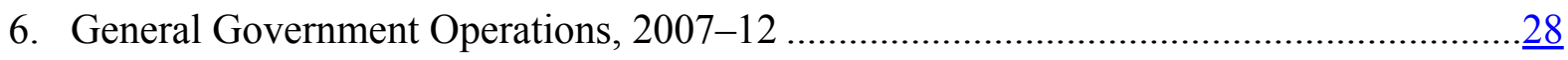

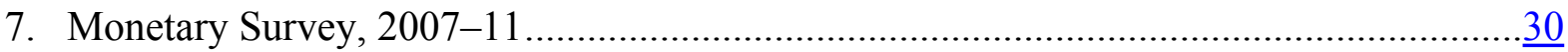

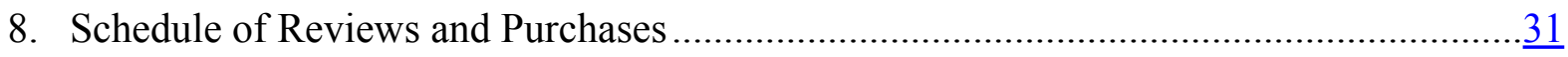

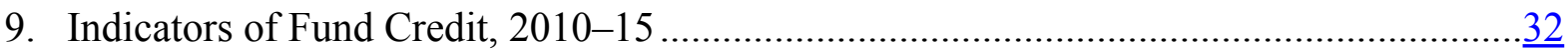

10. Public Sector Debt Sustainability Framework, 2007-15 …………............................

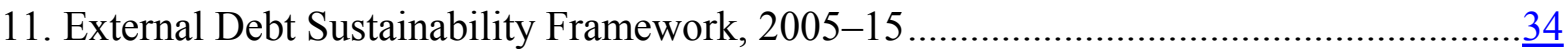

Appendices

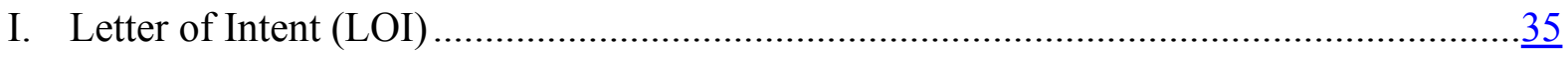

II. Technical Memorandum of Understanding ……….................................................... 


\section{INTRODUCTION AND SUMMARY}

1. The economy is now stabilizing and growth is set to resume. GDP fell in Q3, but indicators now point to a resumption of growth in late 2010 or early 2011 . Growth is expected to be $1-1 \frac{1}{2}$ percent in 2011 , after -2 percent in 2010 . Inflation is projected to peak slightly above 8 percent late this year due to the VAT increase, before returning to the central bank's target range of 3 percent \pm 1 ppt. by end- 2011 .

2. The program remains broadly on-track. The performance criteria for endSeptember 2010 have been met except for the criterion on government payments arrears. Arrears in the central government and social system fell sharply due to significant payments made in September, and the authorities have agreed to keep them near zero for the remainder of the program. However, local government arrears continue to climb and will only begin to fall when new legislation on local financing takes effect in 2011. The indicative target on current government expenditure was met, but the target on the operating balance of stateowned enterprises was missed by a substantial margin. Structural benchmarks on the 2011 budget (including ratification of the recent VAT increase), and approval of unified wage legislation will be met as prior actions for concluding this review. Other prior actions are the enactment of previously approved pension reform legislation (\$4) and modification of a

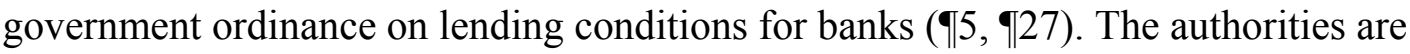
committed to meeting all prior actions by year-end, but staff is concerned that the lending ordinance modification may be delayed.

\section{Fiscal adjustment efforts are bearing fruit, but face implementation challenges.}

The end-September fiscal targets were met with a margin, and end-2010 targets will likely also be met. Combined with prudent expenditure policies, the fiscal measures already enacted should be sufficient to deliver the agreed deficit reduction (to 4.4 percent of GDP) in 2011. Implementation may be difficult, however, as political and judicial pressures to reverse elements of the adjustment are building, and persistent problems controlling health expenditures may endanger the 2011 fiscal objectives.

\section{The structural reform agenda is advancing despite significant political}

headwinds. The authorities expect parliamentary approval of the second round of the unified wage legislation by mid-December, and enactment of the pension reform should happen by year-end (prior actions). The authorities are making progress on reforms of the labor market and of the social benefits system, which will improve its targeting and help mitigate the impact of the austerity package. Public enterprise reforms are lagging, and additional action will be required in the future to prevent a deterioration of their financial position. Improving the absorption of European Union structural funds, which is trailing other EU countries, is critical to securing needed investments under tight budget constraints.

\section{The banking system had been affected by the downturn, but remains well-} capitalized and liquid. Nonperforming loans (NPLs) are likely to continue to grow through mid-2011, due to weak economic activity. Aggregate capital buffers remain large, however, 
with all banks above 11 percent capital adequacy, and the national bank maintains its proactive approach towards securing adequate capital reserves. However, action is needed to ensure that a recent banking ordinance (Ordinance 50) does not produce significant additional losses in the system.

\section{MACROECONOMiC DeVelopments AND OUTLOOK}

\section{A. Recent Developments}

\section{The recovery has been delayed by needed stabilization measures, but the} economy is now stabilizing and growth is set to resume. GDP fell by 0.7 percent in the third quarter, reflecting the effect of fiscal consolidation on domestic demand. With consumer confidence and economic sentiment gradually improving and export oriented industry continuing to grow, recent indicators suggest growth will turn positive in the fourth quarter or early in 2011 (charts and Figure 1). The unemployment rate has begun to fall, but mainly due to shrinking labor force participation rather than job creation.
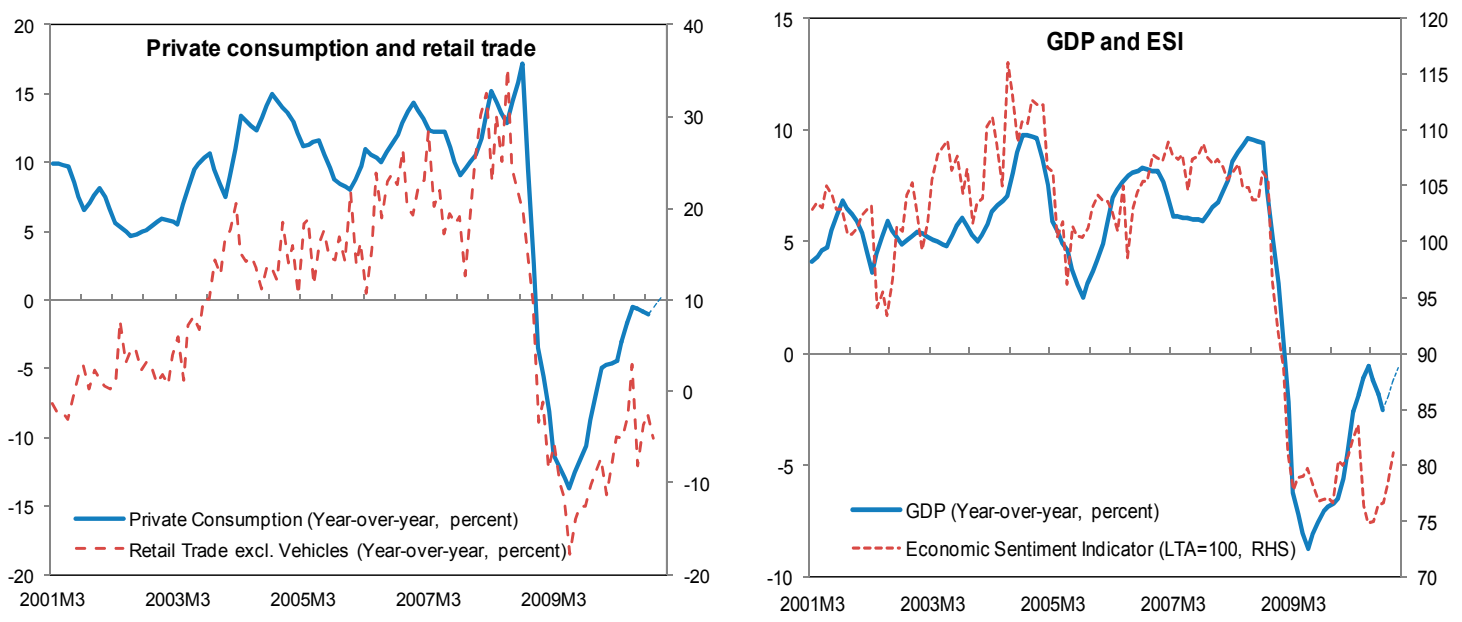

7. Financial market stress has eased further in recent months (charts and Figure 2).

The CDS spread for sovereign debt has narrowed by around 100 basis points since September, leaving them below several other EU countries. Romanian equity markets have recovered somewhat since their June trough. Thus far, the turbulence in the Euro area periphery has had little direct impact on Romania, though risks remain. The leu has

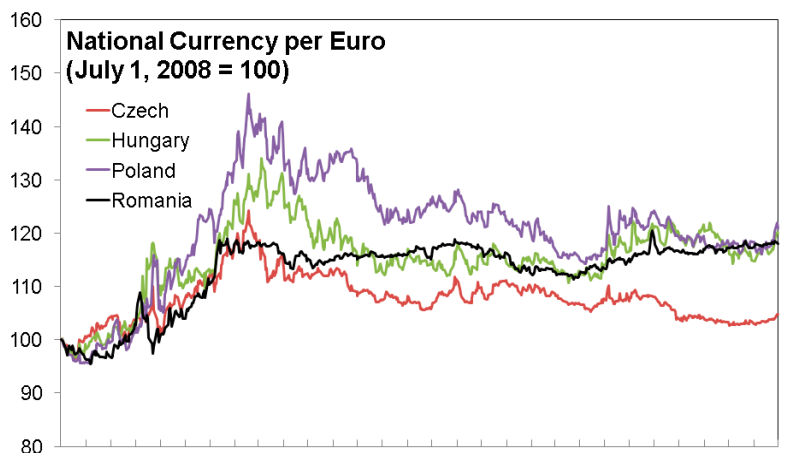

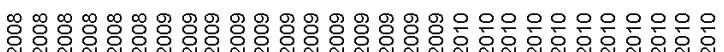

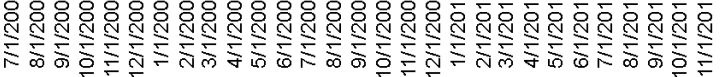

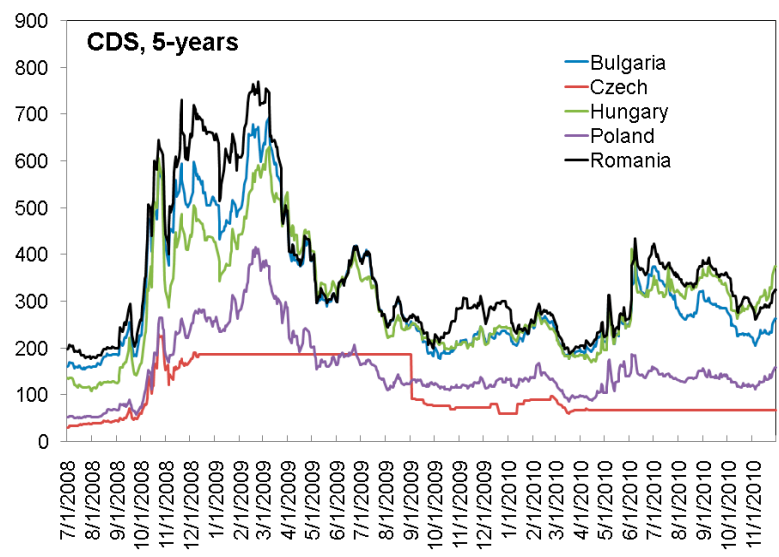


weakened slightly since September, with relatively low volatility due in part to occasional central bank interventions to smooth currency fluctuations.

\section{Monetary conditions continue to ease, supporting a fall in economy-wide interest} rates (charts). Notwithstanding the National Bank of Romania's (NBR's) decision to pause further policy loosening, monetary conditions have moderated further, reflecting continued reductions in deposit and lending rates in the banking system. Lending rates did not fall by as much, however, as banks raised lending margins to cover increased provisioning due to the still rising non-performing loans (NPLs). Weakening of the nominal effective exchange rate has also contributed to the monetary easing.
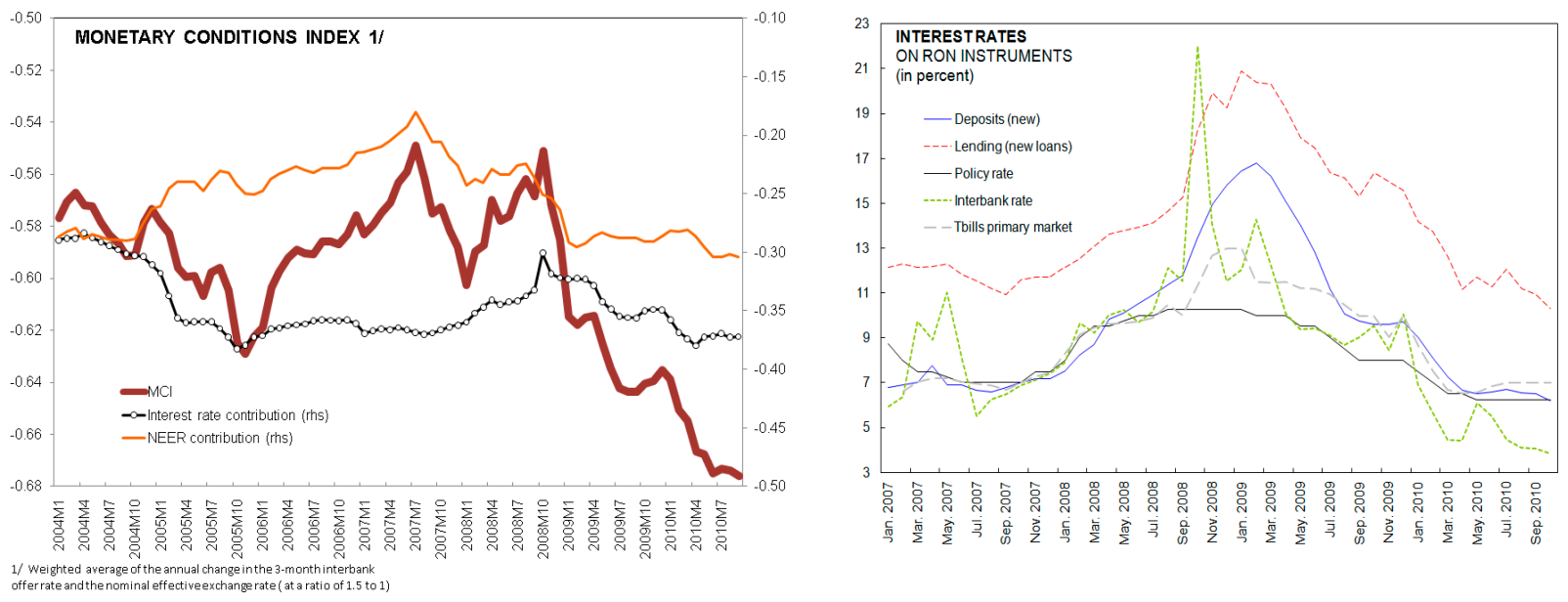

\section{Inflation has increased sharply as a result of the recent increase in the VAT rate} and higher food prices. Headline CPI inflation jumped from 4.4 percent in May to 7.9 percent in October. The initial pass-through of the 5 ppt. VAT hike was roughly as expected, but inflation has been boosted by increased food prices (due to higher world prices as well as recent flooding which disrupted food production in Romania). Prior to the VAT increase, prices were on a firm disinflation trend towards the center of the National Bank' target band of $3 \frac{1}{2}$ percent \pm 1 percentage point (Figure 1).

\section{The banking sector remains} liquid and well capitalized but NPLs continue to rise. NPLs rose sharply in the third quarter, reaching 11.7 percent $^{1}$

\begin{tabular}{|c|c|c|c|c|c|}
\hline \multicolumn{6}{|c|}{ Romanian Banking System - Core Indicators } \\
\hline & Dec-08 & Dec-09 & Mar-10 & Jun-10 & Sep-10 \\
\hline \multicolumn{6}{|l|}{ Capital adequacy } \\
\hline Capital adequacy ratio & $13.8 \%$ & $14.7 \%$ & $15.0 \%$ & $14.3 \%$ & $14.6 \%$ \\
\hline Leverage ratio $^{1}$ & $8.1 \%$ & $7.6 \%$ & $8.1 \%$ & $7.9 \%$ & $7.9 \%$ \\
\hline \multicolumn{6}{|l|}{ Asset quality } \\
\hline Non-performing loans ratio ${ }^{2}$ & $2.8 \%$ & $7.9 \%$ & $9.1 \%$ & $10.2 \%$ & $11.7 \%$ \\
\hline \multicolumn{6}{|l|}{ Profitability } \\
\hline Return on assets & $1.6 \%$ & $0.3 \%$ & $0.6 \%$ & $-0.2 \%$ & $-0.2 \%$ \\
\hline Return on equity & $17.0 \%$ & $2.9 \%$ & $6.0 \%$ & $-1.6 \%$ & $-2.1 \%$ \\
\hline \multicolumn{6}{|l|}{ Liquidity } \\
\hline Loans to deposit ratio & $122.0 \%$ & $112.8 \%$ & $113.2 \%$ & $117.5 \%$ & $116.3 \%$ \\
\hline Immediate liquidity ratio ${ }^{3}$ & $34.4 \%$ & $35.3 \%$ & $37.1 \%$ & $35.9 \%$ & $36.7 \%$ \\
\hline \multicolumn{6}{|l|}{ Source: NBR. } \\
\hline \multicolumn{6}{|c|}{$\begin{array}{l}\text { 1/ Tier } 1 \text { capital/ total average net assets. } \\
2 / \text { Unadjusted exposure from loans classified as "loss" defined as past } 90 \text { days and/or } \\
\text { initiation of legal preceeding/ total loans and interest, excluding off-balance sheet items. } \\
3 / \text { Cash, sight and term deposits with banks plus government securities free of pledge/ } \\
\text { total liabilities. }\end{array}$} \\
\hline
\end{tabular}

\footnotetext{
${ }^{1}$ Using the authorities preferred definition of non-performing loans based upon 90 days past due. The ratio based upon 60 days past due rose to $20.2 \%$.
} 
of total loans at end-September with a notable dispersion around the mean. They will likely continue to increase in the first half of 2011, due to the slow economic recovery and the effects of recent public wage cuts on disposable incomes. The banking system retains adequate buffers, with an average capital adequacy ratio of 14.6 percent at end-September 2010 and with all banks above 11 percent (compared to the statutory minimum of 8 percent). Nevertheless, the authorities will need to maintain vigilance over some small banks (accounting in aggregate for less than 2 percent of system assets), which have seen a rapid deterioration in loan quality and have lower provisions compared to the system average. Lending to the private sector has been flat since early 2009, with declining local currency lending offset by an increase in foreign currency lending that mostly reflects the repatriation of offshore loans. ${ }^{2}$ Lending to the government, on the other hand, now accounts for 20 percent of total bank loans compared to 8 percent at the end of 2008, although crowding out effects appear limited so far due to weak private demand. The nine largest foreign banks under the European Bank Coordination Initiative (EBCI) have maintained an aggregate exposure of 98 percent $^{3}$ at end-October, well above the commitment of 95 percent agreed in July.

11. Romania's external position continues to improve. The current account deficit improved from 131/2 percent of GDP in 2007 to 5 percent of GDP (on a 12-month basis) by September-2010, driven by strongly shrinking trade deficit. Exports are gaining momentum with recovery in major trading partners (driven by manufacturing sector) while depressed domestic demand is limiting import growth. On the transfers side, workers' remittances have shrunk compared to 2009 due to the recession and high unemployment in host economies. Foreign direct investment continue to be weak, financing less than half of the current account deficit, while official financing remained to be the major source of inflows. As a result, the end-September net foreign asset target was met with a margin of some $€ 3.7$ billion. In the remainder of the year, potential outflows are anticipated to be less than $€ 700$ million, as most banks are expected to maintain or expand their operations in Romania.

\section{B. Macroeconomic Framework and Risks}

\section{The macroeconomic outlook remained broadly unchanged compared with the last review, but continues to be subject to large uncertainties:}

- Growth. GDP remains forecast to fall by 1.9 percent in 2010, with growth of $1 \frac{1}{2}$ percent in 2011 as the expected gradual recovery takes hold in late 2010 or early 2011. Domestic demand will only slowly regain momentum after real disposable income was reduced by lower public wages and the VAT hike. Beginning in 2012,

\footnotetext{
${ }^{2}$ High reserve requirements before the crisis resulted in subsidiaries of some foreign banks booking loans to residents offshore. As reserve requirements have been reduced, loans have moved back onto the subsidiaries' balance sheets.

${ }^{3}$ Compared to the exposure at end-March 2009.
} 
demand of households and enterprises should become the main growth engine, as incomes recover, employment generation starts kicking-in, and balance sheet adjustments wind up. Net external demand will gradually cede its place as the main driver of growth, reflecting both stronger domestic demand and slower growth in export markets. Growth should accelerate somewhat above the $3-3 \frac{1}{2}$ percent estimated increase of potential output in 2012-15, allowing for the output gap to close by 2015 .

Risks to this outlook remain large but broadly balanced. On the downside, political tensions could dampen confidence and weaken performance. A weaker-thanexpected recovery in Western Europe could affect Romanian exports. The ongoing turbulence in the Euro area periphery could still spill over into Emerging Europe, raising risk premia and affecting capital flows to Romania. On the upside, the booming export sector could result in stronger spill-over effects to the local economy. The sharp fiscal adjustment undertaken in 2010 could clear the way for a faster recovery of consumer confidence and domestic demand in 2011. Improved absorption of EU investment funds could also catalyze faster growth.

- Inflation. Inflation will remain above the NBR's target band until late-2011 due to the VAT hike and food price pressures. Staff now expects CPI inflation to peak at slightly above 8 percent late in 2010 , before beginning to decline in the course of 2011. Given current weak economic recovery, the second-round effect of the VAT hike is likely to be small. The central bank's 2011 target of

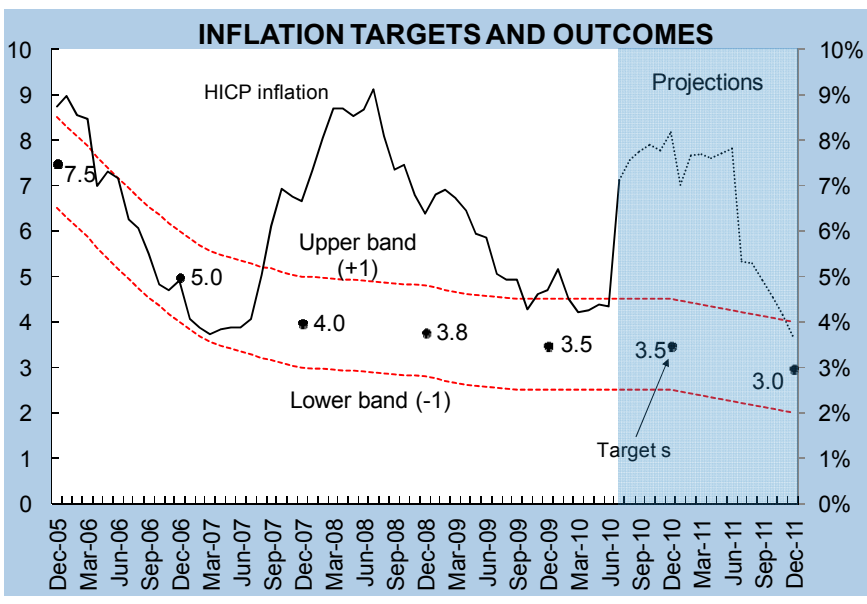
3 percent \pm 1 percentage point is still likely to be met.

Upside risks to the inflation outlook outweigh downside ones. A continued resurgence in world commodity prices may increase food and energy prices by more than currently expected. The need to raise administered prices as part of a more aggressive adjustment process in some public enterprises may also boost inflation. A further weakening of the exchange rate would also generate pressure on the CPI. On the downside, the wide output gap could lead to a smaller-than-projected pass through of the VAT increase.

- $\quad$ External Position. The balance of payments outlook remains broadly unchanged from the previous review. The current account deficit is projected at around $51 / 2$ percent of GDP in 2010, rising to near 6 percent by 2012, slightly above its long-term estimated norm. Despite marked improvement in the goods trade balance, a larger 
services deficit and repatriation of income and weaker remittances and are limiting further adjustment in the current account. Nevertheless, weaker FDI and portfolio inflows coupling with potential outflows due to the revised EBCI agreement are broadly offset by government's financing from official sources.

\section{Romania: Macroeconomic Outlook}

\begin{tabular}{lrrrrrr}
\hline & 2007 & \multicolumn{1}{c}{2008} & \multicolumn{1}{c}{2009} & \multicolumn{1}{c}{2010} & 2011 & 2012 \\
\hline Real GDP growth & 6.3 & 7.3 & -7.1 & -1.9 & 1.5 & 4.4 \\
CPI inflation, average & 4.8 & 7.8 & 5.6 & 6.1 & 6.1 & 3.4 \\
CPI inflation, eop & 6.6 & 6.3 & 4.8 & 8.2 & 3.7 & 3.0 \\
Current account balance (\% of GDP) & -13.4 & -11.6 & -4.2 & -5.5 & -5.6 & -5.9 \\
$\quad$ o/w: private & -10.3 & -6.8 & 3.0 & 1.3 & -1.2 & -2.5 \\
Trade Balance (\% of GDP) & -14.3 & -13.7 & -5.9 & -5.4 & -6.0 & -5.8 \\
Gross international reserves (bn euros) & 28.7 & 28.3 & 30.9 & 33.9 & 38.7 & 41.4 \\
\hline
\end{tabular}

\section{Policy Discussions}

\section{A. Fiscal Policies}

\section{The fiscal adjustment is taking hold, setting the authorities on track to meeting}

this year's targets. The ambitious fiscal package of July 2010 has produced the targeted adjustment in its first few months, backed by a modest turnaround in tax yields, strict expenditure control, and continued streamlining of public employment (down 5 percent from end-2008). ${ }^{4}$ As a result, the end-September deficit and current spending targets were met by a significant margin $(0.8$ percent and 0.3 percent of GDP, respectively), putting the authorities in a good position to meet the deficit target for the year as a whole while also leaving space to clear arrears.

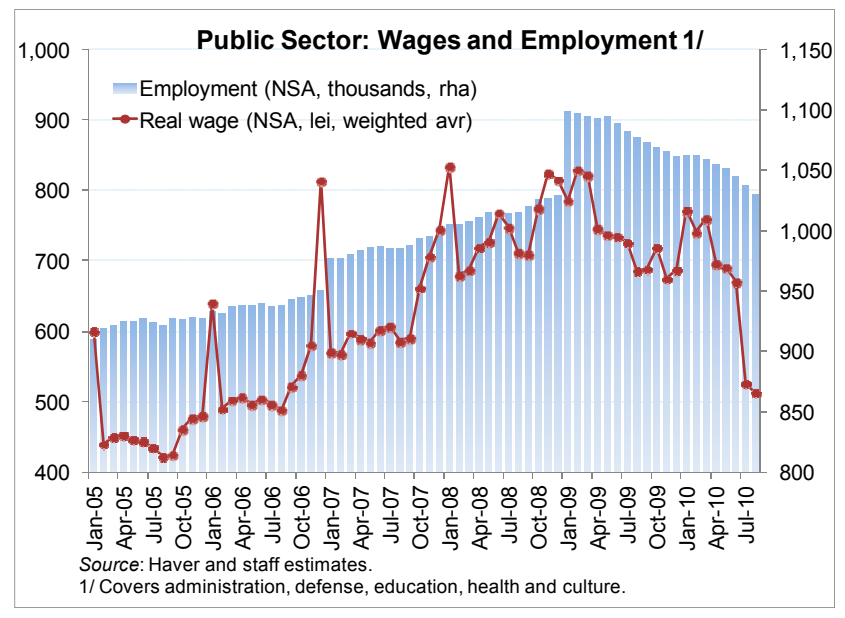

\section{Policies are in place to reach the $\mathbf{2 0 1 1}$ fiscal targets, but there are significant} implementation challenges. The draft 2011 budget relies on the full-year yield of the 2010 adjustment measures and on continued expenditure restraint to reach the targeted 4.4 percent of GDP deficit. These agreed policies include: (i) the elimination of the holiday bonuses and the $13^{\text {th }}$ salary to allow some recovery in public wages within the agreed wage bill ceiling; (ii) continuing the replacement of only one in seven departing civil servants; (iii) the extension of this year's pension freeze; (iv) expanding the base of the healthcare

\footnotetext{
${ }^{4}$ The adjustment package was enacted in July 2010, yielding an annualized 4.6 percent of GDP due to a 25 percent cut in public wages, a 15 percent cut in most social transfers, and a 5 percentage point hike in the VAT rate.
} 
contributions to more pensioners; and (v) the elimination of the heating subsidies. However, the authorities will face a number of implementation challenges on key elements of the adjustment. The assumed reduction in the wage bill depends upon the authorities' ability to retain the bulk of the wage cuts agreed in July 2010 throughout 2011, and on a continued gradual reduction in public employment. ${ }^{5}$ Healthcare reforms will have to effectively overcome the tendency for significant expenditure overruns in the past (see $q 22$ below). The authorities will also have to continue to resist strong political pressures to reduce income taxes or social contributions rates or to boost capital spending beyond sustainable levels. The authorities remain fully committed to taking further measures if any of these challenges threaten to derail their adjustment strategy.

\section{If current policies are} maintained, Romania's fiscal deficit is on track to fall to near 3 percent in 2012. In structural terms, the cash fiscal deficit will fall below 2 percent of GDP in 2011 , representing a correction of nearly 7 percentage points of GDP over three years, bring the structural deficit down from an unsustainable 9 percent of GDP prior to the crisis and allowing the

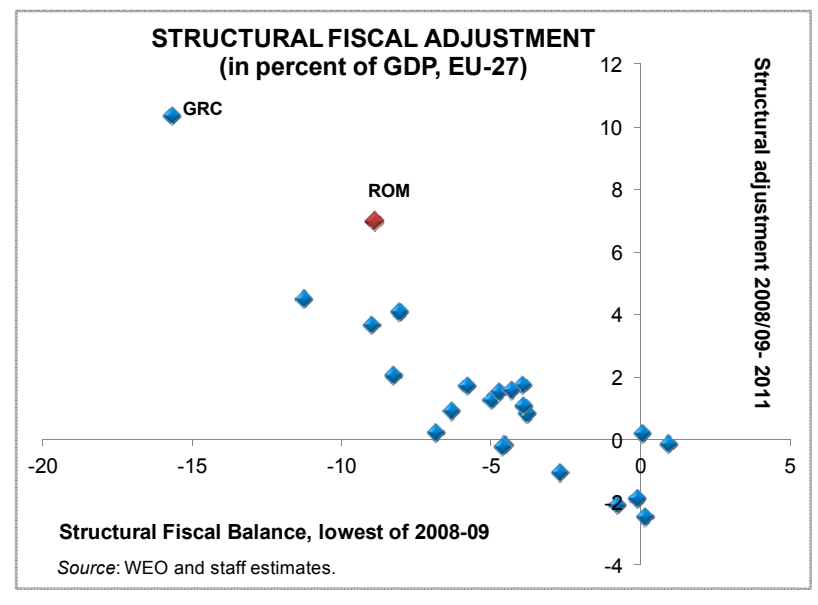
authorities to reach the Maastricht deficit criterion by 2012. With current policies and continued expenditure constraint, the 3 percent headline deficit would translate into a structural deficit of about $1 \frac{1}{2}$ percent of GDP as the effects of structural reforms are felt in pensions, healthcare spending, and social benefits. ${ }^{6}$ Public debt will peak at below 37 percent of GDP in 2011, after which it will decline to about a third of GDP over the medium-term. The authorities, however, will face increased headwinds as expenditure pressures intensify ahead of the 2012 parliamentary elections and as constitutional court decisions may limit the policy instruments available to reign in the wage bill.

\section{The efforts to clear payment arrears continue with the slow} progress. The government has paid off

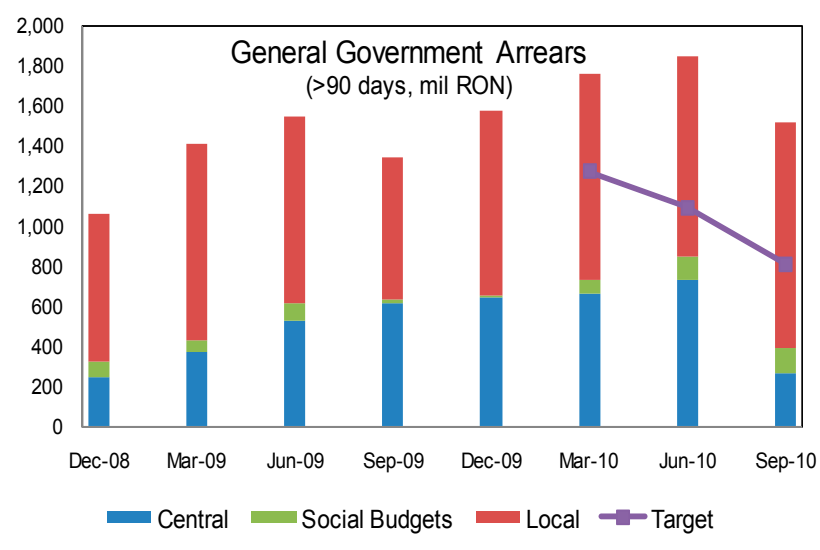

\footnotetext{
${ }^{5}$ The 25 percent wage cut was approved by the Constitutional Court only if applied for a limited time. The opposition has threatened to challenge in the Court its continuation through 2011.

${ }^{6}$ In the recently approved Fiscal Responsibility law, the authorities set an objective of a zero fiscal deficit over the economic cycle.
} 
RON 1.9 billion ( 0.4 percent of GDP) in health arrears and unpaid bills in September, significantly reducing arrears at the central government level (see chart). ${ }^{7}$ In contrast, local government arrears have been rising, and the program target was missed once again. The government will allocate the necessary funds to keep the central government and social security arrears near zero (less than 0.05 percent of GDP) during the duration of the program until the necessary structural reforms, especially in the health sector, take effect. ${ }^{8}$ In November, an FAD TA mission provided additional assistance on integrating accounting and Treasury payment systems to control spending commitments and strengthen budget execution (structural benchmark, March 15, 2011). Local government arrears are expected to grow further before they start a downward trend early next year, when amendments to the local public finance law will require repayment of arrears next year. In addition, WB experts will help improve local government financial management. In line with a new EU directive, the government over time will start reducing the time period for paying bills after submission to no more than 30 days during 2011 and 2012.

\section{The fiscal financing strategy will be recalibrated towards higher reliance on} longer-term market financing and larger financing buffers. Over the last several months, the authorities limited their regular market access to short maturity instruments as local currency yields surpassed their comfort level. However, beginning in November, they have begun to focus on extending the maturity of their domestic currency debt while accepting somewhat higher yields, with a view to building a yield curve and building their financing buffers. They also successfully rolled over (with an increase in maturity) a large domestic euro-denominated syndicated loan with local banks. They also plan to launch a "euro medium term notes" program in late 2010 or early 2011 that will maintain their presence in the external markets

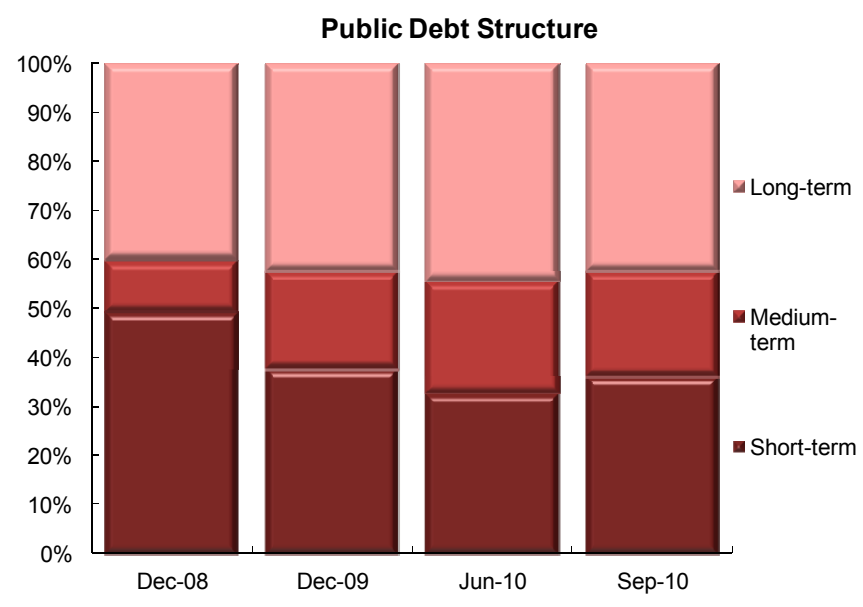
under more flexible issuance procedures. A formal review of the government's debt management strategy, with the assistance of the IMF the EC, and the World Bank, is planned for 2011.

\footnotetext{
${ }^{7}$ From the payments made in September, arrears were reduced by some 500 million, with the remainder used for overdue bills which would become arrears if not paid.

${ }^{8}$ To comply with the prior action of maintaining near-zero central government and social security arears at endNovember, additional payments of around RON 500-600 million would be required.
} 


\section{B. Structural Reforms}

\section{Key reforms in public sector wages and employment are advancing.}

Approval by parliament of the unified wage law for the public sector is expected in December (prior action). The framework law provides the new job categories and wage scale. The parameters for 2011 defined in the implementation law will ensure that: (i) the public wage bill remains within the agreed envelope for 2011; (ii) all remaining bonuses are set as ceilings rather than mandatory levels, both at an individual and aggregate level, allowing for flexibility according to performance and budgetary conditions; and (iii) the productivity bonus system (stimulente) will be eliminated by incorporating it into the basic wage, while allowing some flexibility for rewarding strong tax collections within the overall bonus ceiling. Full application of the new wage system will take several years, however. Reductions in public employment are on track. By end-October, some 88,000 jobs had been cut, bringing the year-end target of 100,000 into reach.

\section{The enactment of the pension reform is expected in December (prior action).}

After parliament's approval of the law in September, enactment of the pension reform was delayed because the president returned it to parliament to reconsider the pension age of women. Final approval was achieved on December 7, and enactment should occur by yearend. ${ }^{9}$ The government remains committed to increase the contributions to the second pillar to 3 percent in 2012 and to preserve current operating conditions for the private funds.

\section{The authorities continue work on labor market and social benefits reforms to} improve growth prospects and the efficiency of public spending. The Ministry of Labor has finalized a draft of reforms in the collective bargaining process to increase representativeness in the negotiations between social partners. ${ }^{10} \mathrm{~A}$ law on day workers has been submitted to the parliament, and an apprenticeship law has been drafted to provide young people better access to the labor market. The authorities have also made efforts to improve training programs to low-skilled workers. Efforts continue on improving the efficiency of social protection while providing support for fiscal adjustment. A social benefits reform, which has already been submitted to parliament, will consolidate the guaranteed minimum income benefit, heating subsidy and family allowance into one new means-tested scheme. Disability allowances will also be subject to incomes testing. The current maternity benefits will be streamlined to be more in line with the average EU standard. To reduce the significant rate of benefits fraud detected in recent inspections and increase spending efficiency, the authorities have doubled the personnel working on social benefit inspection and are expanding the range of programs subject to inspections to all programs that are high risk of irregularities.

\footnotetext{
${ }^{9}$ The approved version adjusts the pension age for women to 63 (compared to 65 in the original law). Currently, the retirement age for women is only 58.

${ }^{10}$ The law would consolidate the Trade Union law, the Employers Law, the Economic Council Law and the Law on Collective Agreements.
} 


\section{Bold reforms in the health sector are critical to secure the success of the fiscal} consolidation strategy. While authorities continue to implement measures to reduce healthcare costs (see LOIs of June 16, June 29 and September 9, 2010), these have proven insufficient to balance the much reduced budget for the health system without accumulating arrears. The government will therefore continue restructuring the health sector to ensure the functioning of the health care system within budgetary allocations going forward. On the revenue side, legislation will be approved to establish a copayment for most healthcare services and to make the recently approved tax on drug suppliers operational. On the spending side, the hospital network will be rationalized and the government will restructure its contracting of healthcare services to cap the contracts to budgeted amounts, to contract on a competitive rather than on hitherto universal basis, to reduce the imputed profits for drug suppliers, and continue the gradual move from a per-patient to a per-service reimbursement of primary healthcare providers. The authorities will also review and streamline, with help from the World Bank, the package of benefits insured by the government, and will develop an IT system for pricing medical services. These reforms are anticipated to yield at least 0.4 percent of GDP in savings during 2011.

\section{Tax administration reforms to improve collections and fight evasion are}

ongoing. Legislation approved in June to deal with VAT and excise tax compliance has started bearing fruit, as collections have recently begun to improve. Additional legislation on high net wealth individuals is under preparation (end-December structural benchmark). The legislation will allow for a broader definition of income and will strengthen audits of unreported income. An IMF expert is expected to assist in the implementation of the law, and a mission is tentatively planned for early next year. To concentrate tax administration's resources on medium and large taxpayers, the government will request a shift in the VAT mandatory registration threshold from the EC Council of Ministers to EUR 50,000, supported by a simplified taxation option for taxpayers below the threshold. As about 80 percent of revenue comes from 25,000 largest taxpayers, tax administrators will implement new criteria to allocate taxpayers into small, medium, and large segments and focus attention on the large segment. The introduction of information technology systems is ongoing. The electronic filing for large taxpayers is now in place, and necessary equipment to fight tax evasion is being provided to tax administration and customs offices. A newly introduced right to freeze assets and accounts has also improved compliance.

\section{Progress concerning privatization and performance of state-owned enterprises}

(SOEs) remains limited. Revised data indicate that the 10 largest loss-making public enterprises failed to meet the indicative target for operating losses in the second quarter, and the third quarter was also missed by a wide margin. Moreover, payments arrears have continued to increase. Deficits of the 10 largest loss-making enterprises through endSeptember totaled about $3 / 4$ percent of annual GDP, while their gross arrears stood at roughly 3 percent of GDP (roughly 10 times those monitored under the general government target).The government continues efforts to improve the performance of public enterprises. Measures have been taken to improve the revenue side of these companies (via higher tariffs) 
24. as well as cost reductions via personnel cuts and restructuring, but progress is slow. Many of the firms have deeply entrenched imbalances, inadequate management and supervision, and strong trade unions resistant to change.

\section{The government is stepping up efforts to improve the absorption of $\mathbf{E U}$} structural funds for investment. Planning and execution of infrastructure projects is hampered by several legal, administrative and institutional factors, leading to absorption of less than 3 percent of EU structural funds available for 2007-2013. To address this, the government will take several measures including: restructuring key investment units, improving public procurement procedures, streamlining the portfolio of investment projects and focusing on those financed by EU funds, and encouraging greater private sector participation in investment projects. The government will move the EU project management unit from the Ministry of Finance to the Prime Minister's office and strengthen its authority and staffing, and will create facilities for reallocating the capital budget during the year to those ministries with the best absorption performance.

\section{Financial Sector Policies}

26. The authorities continue efforts to strengthen the financial safety net. To improve the effective resources of the Deposit Guarantee Fund (DGF), a decision to increase bank contribution rates and eliminate the stand-by credit lines with banks was adopted (structural benchmark). Legislative reforms to the DGF's governance structure to prevent bank employees from participating in its Board are on track for end-December (reset structural benchmark). The authorities have also committed to make a further legislative change to allow DGF funds to be used more flexibly in the event of bank distress (structural benchmark mid-March). In addition, the IMF has provided technical assistance on preparation and implementation of the new bank resolution powers and on liquidity stress testing.

\section{The authorities will take steps to revise a recent government ordinance which} could significantly exacerbate banking sector losses. The measure (Ordinance 2010/50) was originally intended to implement an EU directive for improving the transparency of lending practices by eliminating certain bank fees and obliging banks to index floating rate loans only to independent indices. However, it has been applied retroactively to pre-existing contracts without allowing bank to compensate for lost fees or for lower interest rate indices, imposing significant costs on banks. It has also given the consumer protection agency broad power to suspend banks' lending activities, undermining the NBR's role as the regulator of the system. The authorities have committed (prior action) to either eliminate the retroactive element in the current legislation or to allow the banks to re-adjust the terms of pre-existing contracts so as to avoid potentially destabilizing losses, and to clarify that the NBR will remain the sole agency with authority to suspend banks' activities. 


\section{Monetary and Exchange Rate Policies}

28. The central bank has left its easing cycle on hold, pending a clear signal that inflationary pressures are receding. After a 4 percentage point cumulative reduction in interest rates since early 2009, the NBR has left its key policy rate unchanged since July due to uncertainties associated with the VAT increase and food prices. Reserve requirements have remained unchanged since November 2009 but at relatively high levels ${ }^{11}$. The authorities believe that heightened vigilance will be needed to keep inflation expectations in check and stave off possible second-round inflationary effects, and intend to be cautious in resuming monetary easing only when inflation risks are believed fully under control. Interventions in the foreign exchange market have been quite

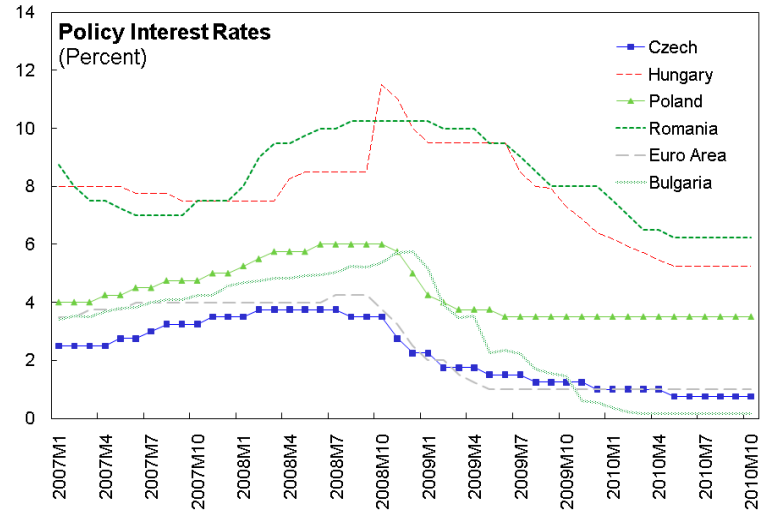
limited in recent months, allowing full exchange rate flexibility, while occasionally smoothing excessive fluctuations. Looking forward, monetary policy will be geared towards reaching the projected disinflation path net of the tax effect.

\section{Program Modalities}

29. The attached Letter of Intent (LOI) describes the authorities' progress in implementing their economic program and sets out their commitments through March 2011.

- $\quad$ Some modifications to the program's conditionality are proposed (Tables 1-2): (i) the end-November structural benchmark for reforming tax administration for high net wealth individuals will be reset to end-December 2010; (ii) the structural benchmark for end-March 2011 on integrating the accounting reporting system with the Treasury payment system is modified to the first phase of the integration project, which would include completing the tender for consultants to implement the project and a full project plan should be in place by March 15, 2011; (iii) the end-September structural benchmark on the reform of the DGF governance arrangement is reset to endDecember 2010.

- $\quad$ One new structural benchmark is proposed (Table 2): An amendment to the legislation on the Deposit Guarantee Fund (DGF) to permit resources to be used to

\footnotetext{
${ }^{11}$ The reserve requirements are 25 percent for foreign currency liabilities under 2 year maturity and 15 percent for short-term local currency liabilities.
} 
facilitate bank resolution, including purchase and assumption transactions (March 15, 2011).

- $\quad$ A net foreign asset performance criterion is proposed for end-January 2011.

30. Program modalities. The Fund arrangement remains adequate to meet Romania's balance of payment needs through end-2010, alongside financing commitments from the European Union and the World Bank. No changes are therefore proposed to the level of access or the schedule of purchases (Table 8).

31. Romania's capacity to repay the Fund is expected to remain strong. Fund credit outstanding would peak in 2010 at 36 percent of gross reserves (Table 9). Peak payments would be in 2013-14 at a still manageable 11.7 and 12.0 percent of gross reserves, respectively. While this exposure remains large, the associated servicing risks are mitigated by the relatively low level of public debt (under 37 percent of GDP), with public external debt peaking at around 16 percent of GDP in 2011 (Table 6). Total external debt is projected to increase to about 82 percent of GDP at end-2011 from 51 percent at end-2008, but a return to economic growth would gradually reduce it to manageable levels in the medium term (Table 11). Romania's strong political commitment to the SBA program and its excellent track record servicing external obligations also provide comfort that it will fulfill its financial obligations to the Fund in a timely manner.

\section{Fund staff has continued to cooperate closely with the staff of the European} Commission (EC) and the World Bank (WB). Staff from the three institutions consults regularly regarding developments in Romania, and IMF, EC and WB staff participated in joint missions. The EU has disbursed the first three tranches of its support ( $€ 3.7$ billion), and two additional tranches are expected in 2011 ( $€ 1.4$ billion). The WB has disbursed its first tranche ( $€ 0.3$ billion) in September 2009, with the remaining tranches ( $€ 0.7$ billion) expected in the first half of 2011.

\section{Staff Appraisal}

\section{Romania is beginning to reap the benefits of the difficult adjustment measures} implemented under the program. Government revenues are improving and expenditures are falling, putting the government on track to reach its 2010 fiscal deficit. The 2011 deficit target is also in reach without major significant additional measures. The fiscal consolidation is in turn feeding a continued improvement in the risk premium on Romania in international financial markets, notwithstanding the considerable uncertainties in the Euro zone periphery. While the economic recovery has been delayed by the weak domestic demand (in part due to the needed fiscal consolidation), exports are booming and high frequency indicators suggest that GDP growth is set to resume in the coming quarters. 


\section{Box 1. Romania: Stand-By Arrangement}

Access: SDR 11.443 billion.

Length: 24 months.

Phasing. SDR 4.37 billion was made available upon Board approval of the arrangement on May 4, 2009, and the subsequent four disbursements amounting to SDR 5.43 billion were made during September 2009-September 2010 with the completion of the first through fifth reviews (Table 8). The sixth disbursement amounting to SDR 769 million will be made available subject to the completion of this review. One final disbursement of SDR 874 million is contingent upon completion of the seventh review (March 2011).

\section{Conditionality}

\section{- Quantitative Performance Criteria}

$>$ A floor on the change in net foreign assets

$>$ A ceiling on general government domestic arrears

$>$ A floor on the overall general government cash balance

$>$ A ceiling on general government guarantees

$>$ Non-accumulation of external debt arrears

- Quantitative Indicative Target

$>$ A ceiling on general government current primary spending

$>$ A floor on the operating balance of the 10 largest loss-making SOEs

- A consultation band around the 12-month rate of inflation of consumer prices

- Prior Actions

$>$ Parliamentary approval of the 2011 budget including ratification of the 24 percent VAT rate

$>$ Parliamentary approval of framework and implementing legislation for the unified wage law

$>$ Enactment of the pension reform legislation

$>$ Amendment of the ordinance on credit contracts (Ordinance 2010/50)

- Structural Benchmarks (Pending and Proposed)

$>$ Parliamentary ratification of the fiscal adjustment measures September 30, 2010 (ratification of the VAT hike reset as prior action in conjunction with budget approval)

$>$ Passage of framework and implementing legislation for the unified wage law October 31, 2010 (reset as prior action)

$>$ Reform tax administration methodology for high net wealth individuals December 31, 2010 (reset from November 30, 2010)

$>$ Parliamentary approval of agreed 2011 budget December 15, 2010 (reset as prior action)

$>$ Complte the first phase of integration of the accounting and Treasury payment systems March 15, 2011 (modified and reset from March 30, 2011)

$>$ Reforming DGF's governance regime December 31, 2010 (reset from September 30, 2010)

$>$ Amend legislation to allow for DGF resources to facilitate bank restructuring March 15, 2011 (proposed) 


\section{However, in order to fully restore confidence, the authorities must resist} pressures to backtrack on policy implementation. Political forces are increasingly pushing for a reversal of components of the fiscal adjustment package. Resistance to key structural reforms is also mounting. While the authorities have thus far resisted these pressures, continued policy uncertainty can prove detrimental to market sentiment and adversely affect recovery prospects. The fiscal measures, along with signature reforms such as the pension reform, unified wage legislation, and the fiscal responsibility law, should be given the time needed to generate positive economic dividends in 2011 and beyond.

\section{By the conclusion of this review, key structural reforms will be in place to} generate a permanent improvement in the public finances. The pension and public wage reforms are two major pillars supporting the adjustment effort; together they are expected to generate several points of GDP of fiscal savings in future years while improving the efficiency of remaining expenditures. Staff firmly supports the authorities' efforts to streamline public employment, as it will allow some recovery in real incomes of the remaining, better-qualified, employees. We also welcome the authorities' initiatives to reform labor markets and the inefficient social benefits system. Further action is needed to bring healthcare spending fully in line with budgetary allocations, however. Efforts to improve tax collections are also beginning to show results, and should be expanded in order to bring the yield from major taxes more in line with that of other EU countries.

\section{The authorities have wisely begun to normalize their fiscal financing. Given} severe financial market difficulties in other EU countries, the authorities should place priority on rebuilding financial buffers and on developing a full range of debt instruments and maturities to cushion against future shocks. The development of a full yield curve in the public sector will also have positive effects on financial market development.

\section{While some progress has been made, the problem of domestic government} payment arrears remains a drag on the economic recovery. While the size of the arrears is small ( 0.3 percent of GDP at end-June), it has become clear over time that they are symptomatic of deeper problems of lack of adequate monitoring and control over public spending at all levels. Repayment of arrears would provide major benefits in terms of unblocking financial payments in the economy, as currently suppliers to the government are in turn unable to pay their obligations on a timely basis, causing multiplier effects throughout the economy. It will also permit a better allocation of public spending to areas of future priority rather than to the areas of past indiscipline.

\section{The failure to meet the indicative targets on public enterprise deficits and} $\operatorname{arrears}^{12}$ points to the need for much more comprehensive action in SOEs. The measures

\footnotetext{
${ }^{12}$ The EU has an indicative target on the arrears of the 10 largest SOEs in parallel with the Fund target on their losses.
} 
taken to date to improve revenues and cut expenditures are dwarfed by the magnitude of the problem. Beyond the fiscal impact of these firms, it is clear that they are generating significant drag on the economic recovery as a whole. Their payments arrears to suppliers starve private sector firms of needed liquidity and their inefficiency in key sectors like transport and energy raises costs for firms throughout the economy.

\section{Staff urges the authorities to take all actions needed to improve the absorption of} the EU funds. This improvement will have positive effects throughout the economy. The inflows of grant money will help the balance of payments. Increased investment resources will reduce pressure on the authorities' own fiscal resources for capital expenditures. Properly designed and executed projects could provide an engine of growth in the economy, with immediate multiplier effects and improved infrastructure for other economic activities.

\section{Staff supports the pause in monetary easing in the wake of the VAT increase.}

The authorities should gear their future policy decisions towards reaching the projected disinflation path net of the tax effect by end-2011. If inflation develops as currently forecast, the NBR would likely be in a position to resume gradual reductions in interest rates and reserve requirements by midyear. Of course, continued vigilance will be needed to forestall second-round effects from the VAT hike and higher administrative prices.

\section{Financial system defenses against the crisis have proven resilient, but continued watchfulness will be needed given risks from uncertainty in other EU countries and} further asset quality deterioration. The authorities' proactive approach to monitoring and securing adequate capital buffers will need to continue until economic recovery takes hold and NPLs finally begin to stabilize around mid-2011. Reforms of the bank resolution framework and of the deposit insurance fund agreed under the program have either been completed or are underway. Staff supports the authorities' commitment to modify Ordinance 50 , which otherwise would pose risks of significant additional losses in some banks, and would undermine NBR control of banks' lending activities.

\section{On the basis of Romania's performance under the SBA, staff supports the} authorities' request for completing the sixth review. Staff also supports the approval of a waiver of applicability for the end-December targets for which data are not available, and a waiver of nonobservance of the end-December 2010 performance criterion on the accumulation of domestic arrears on the basis of the small nature of the deviation and the corrective actions undertaken by the government. Staff also recommends approval of the modification of program conditionality, as proposed by the attached Letter of Intent. 
Figure 1. Romania: Recent Economic Trends
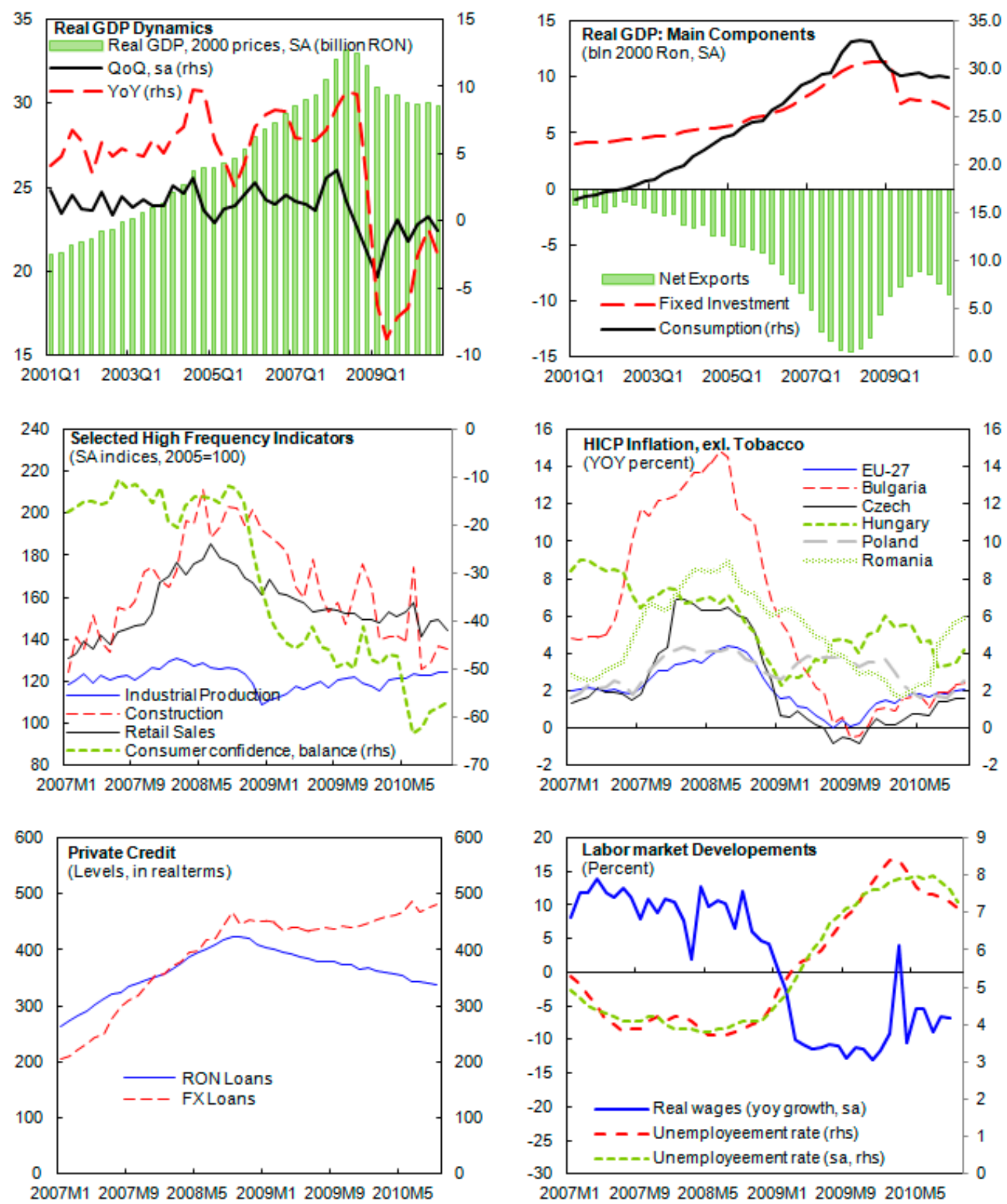

Source: Haver: IMF Staff Estimates. 
Figure 2. Romania: Financial Developments

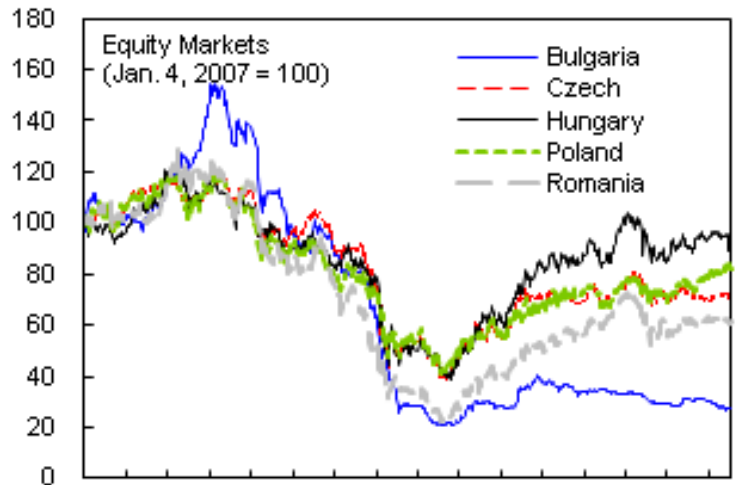

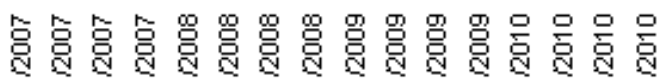

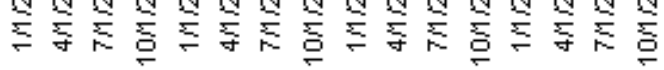
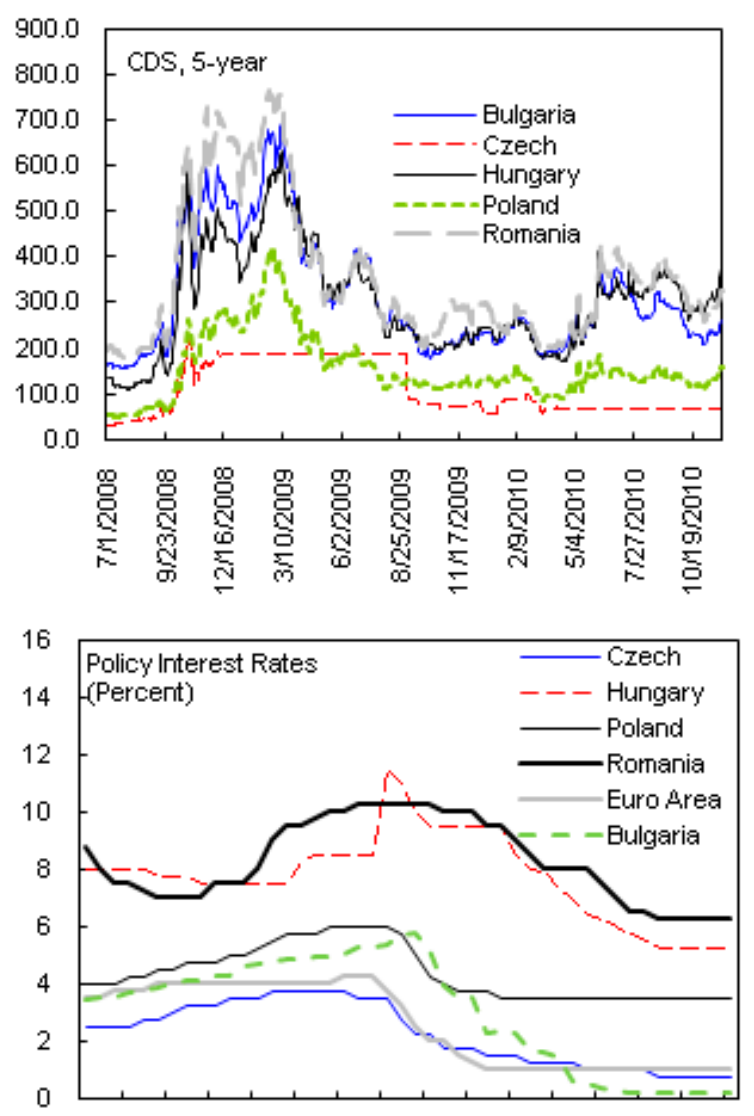

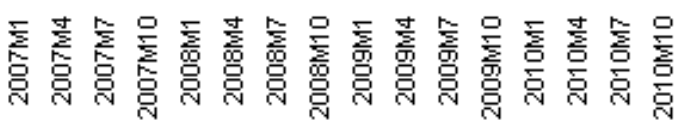
Source: Bloomberg; Haver.
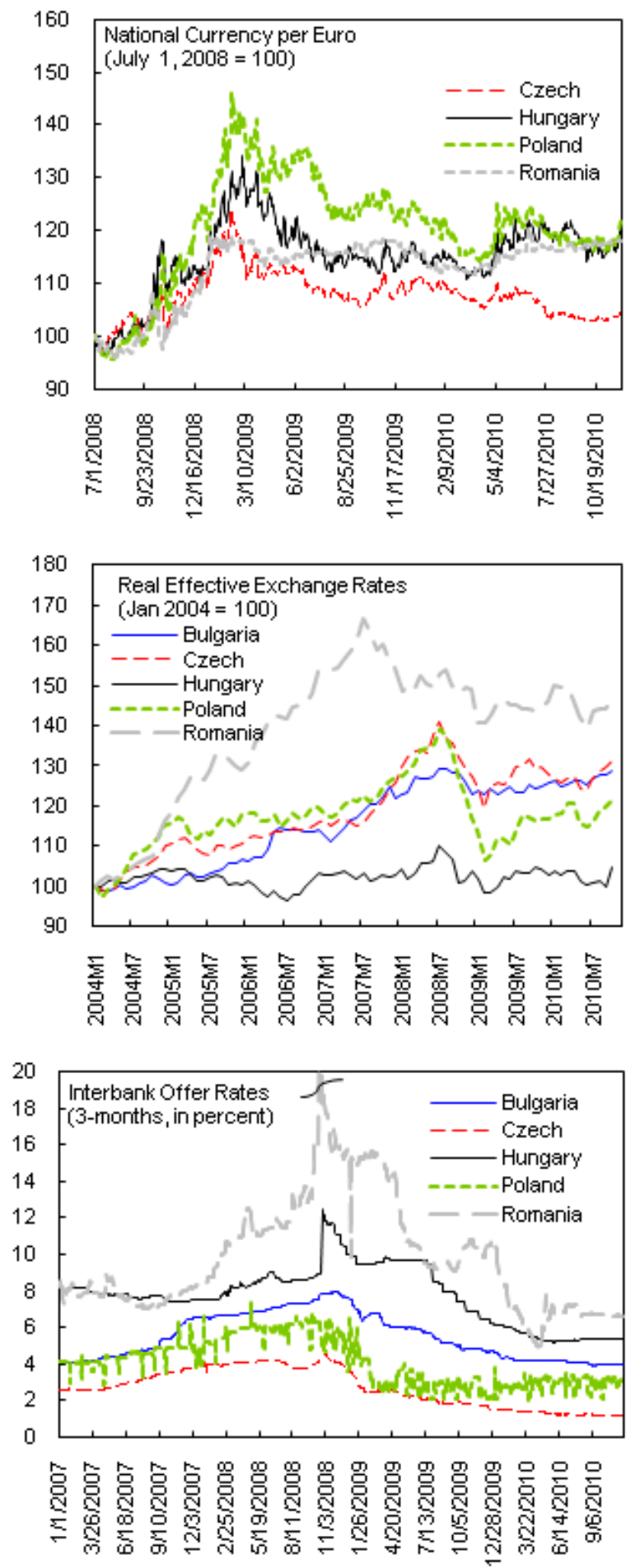


\section{Figure 3. Romania: Public Debt Sustainability: Bound Tests 1/ (Public debt in percent of GDP)}

Baseline and historical scenarios

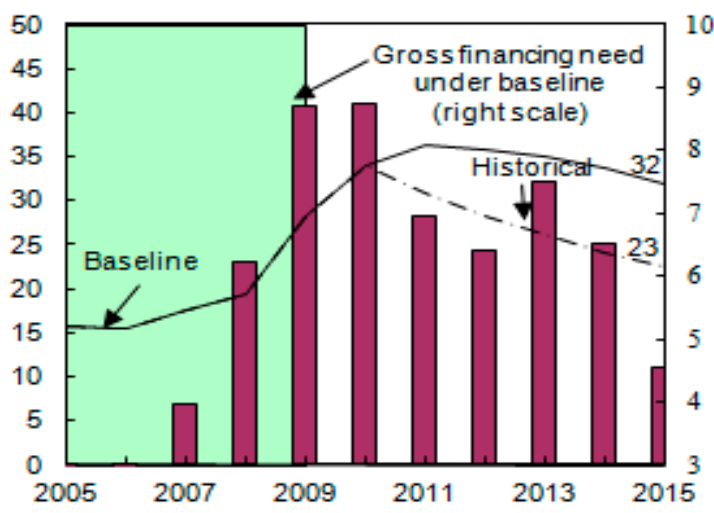

Growth shock (in percent per

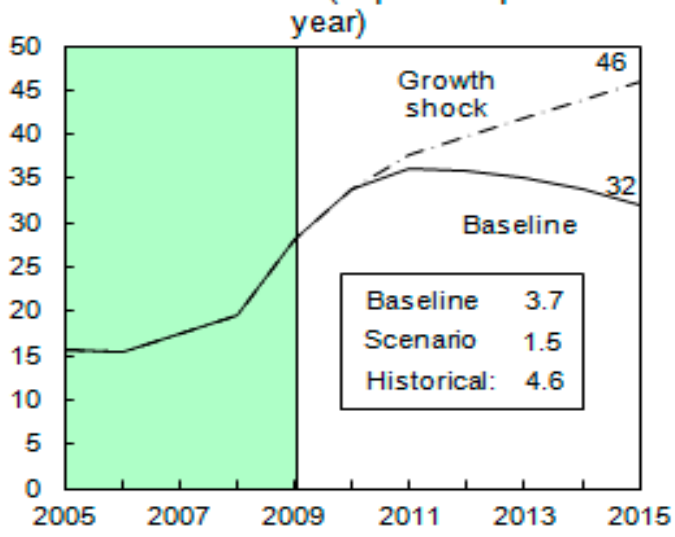

Combined shock $2 /$

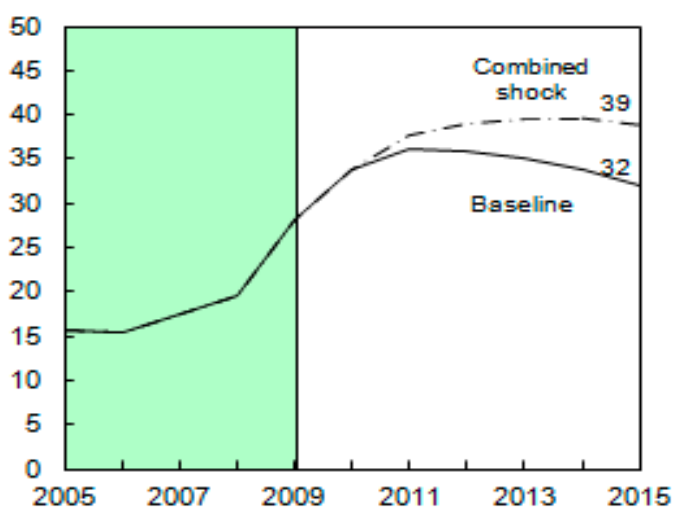

Interest rate shock (in percent)

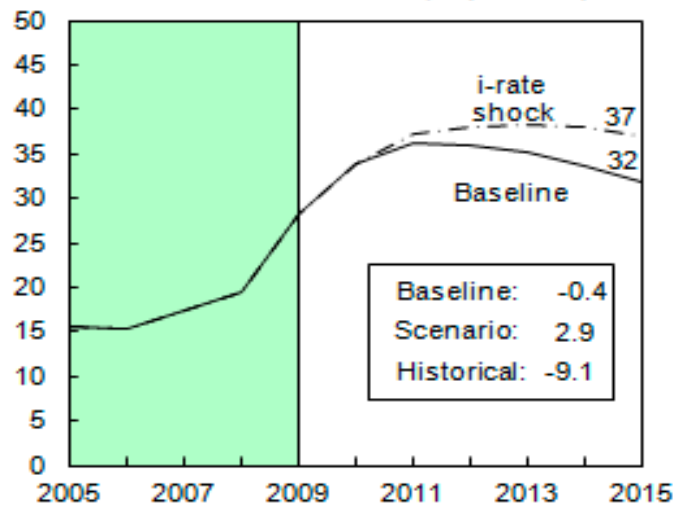

Primary balance shock (in percent of GDP) and no policy change scenario (constant primary

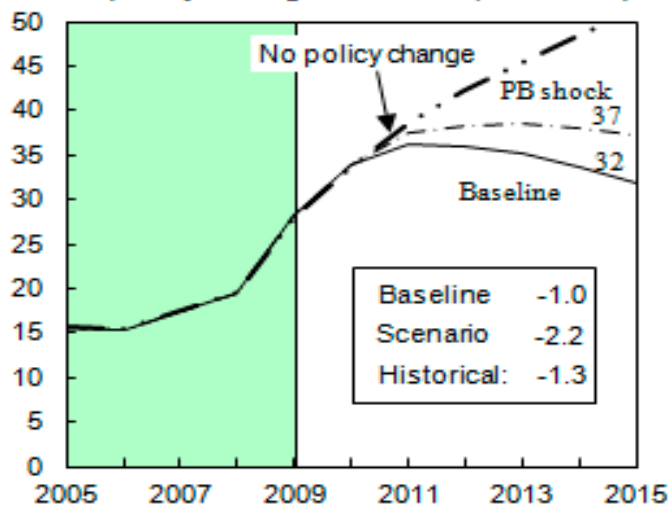

Real depreciation and contingent liabilities shocks 3/

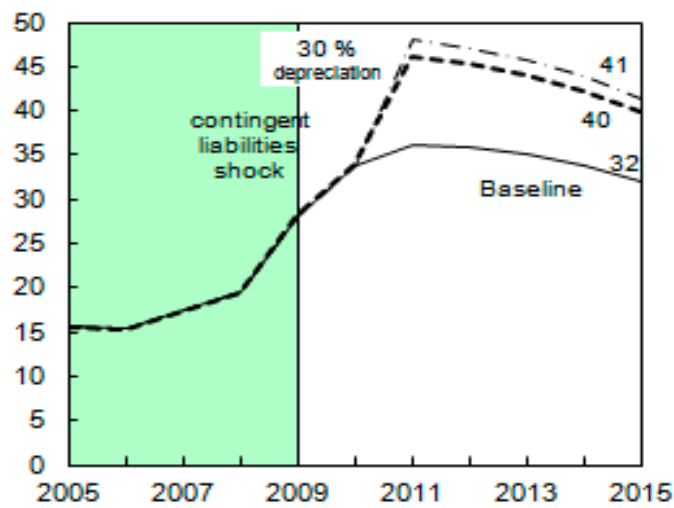

Sources: Intemational Monetary Fund, country desk data, and staff estimates.

$1 /$ Shaded areas represent actual data. Individual shocks are permanent one-half standard deviation shocks.

Figures in the boxes represent average projections for the respective variables in the bas eline and scenario being presented. Ten-year historical average forthe variable is also shown.

$2 /$ Permanent $1 / 4$ standard deviation shocks ap plied to real interest rate, growth rate, and primary balance.

$3 /$ One-time real depreciation of 30 percent and 10 percent of GDP shock to contingent liabilities occur in 2010 , with real depreciation defined as nominal depreciation (measured by percentage fall in dollar value of local currency) minus domestic inflation (based on GDP deflator). 
Figure 4. Romania: External Debt Sustainability: Bound Tests 1/ (External debt in percent of GDP)

Baseline and historical scenarios

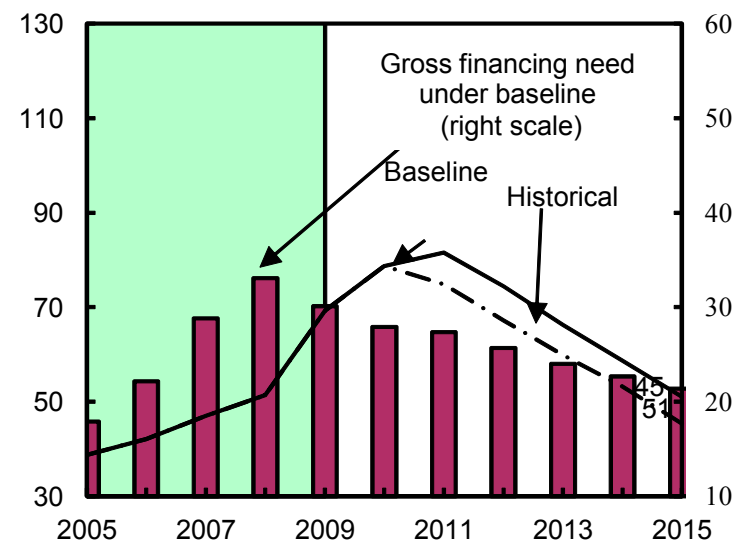

Growth shock (in percent per year)

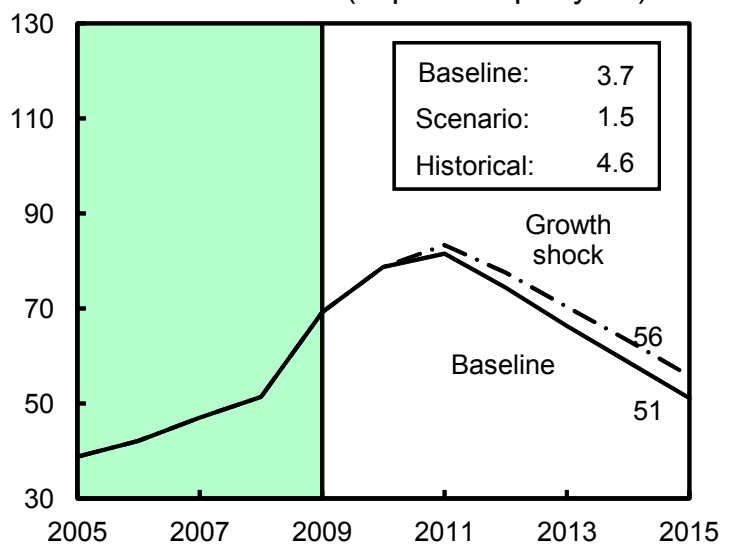

Combined shock 2/

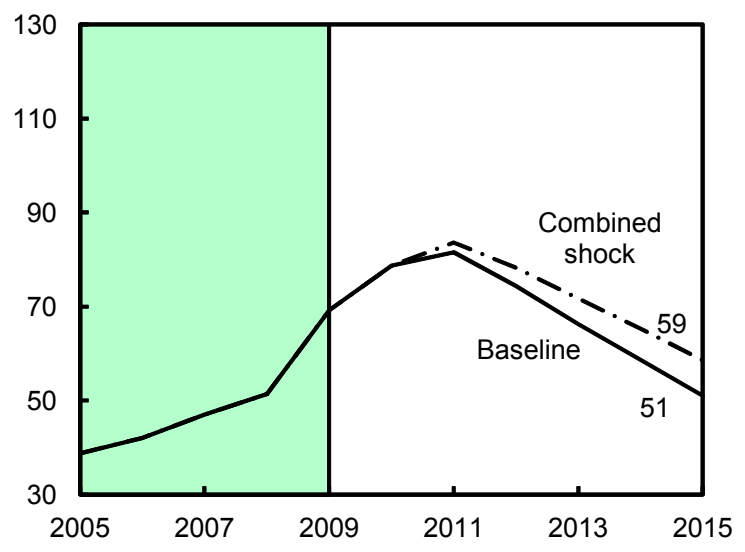

Interest rate shock (in percent)

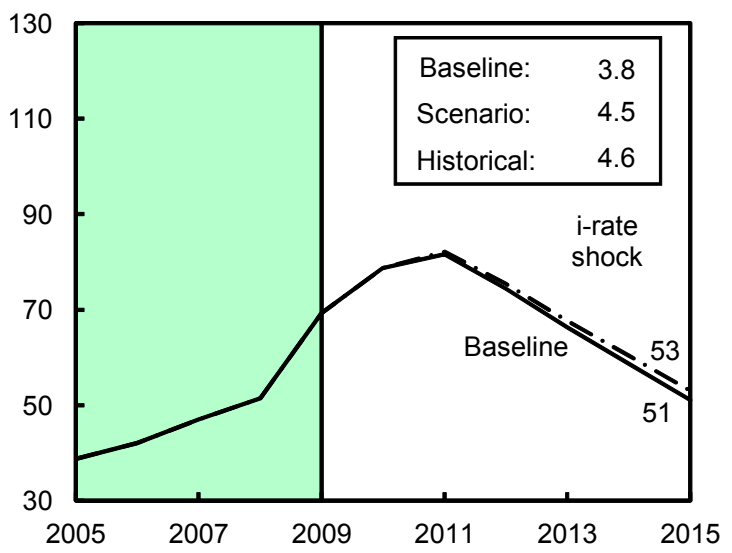

Non-interest current account shock

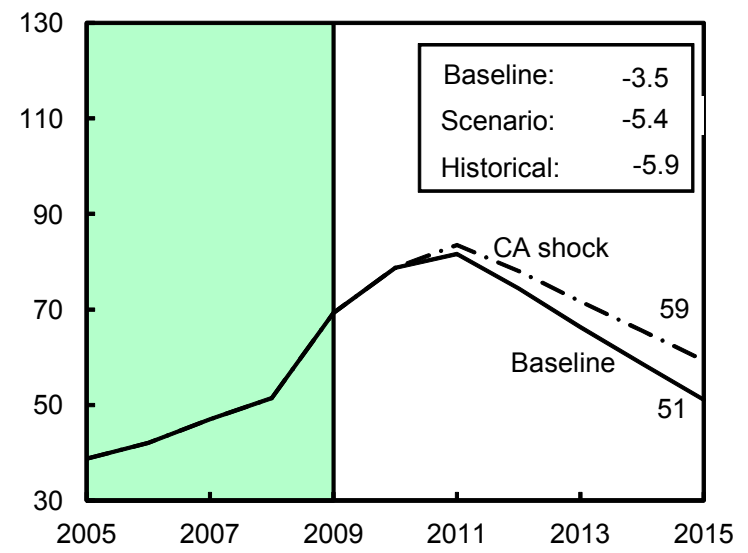

Real depreciation shock $3 /$

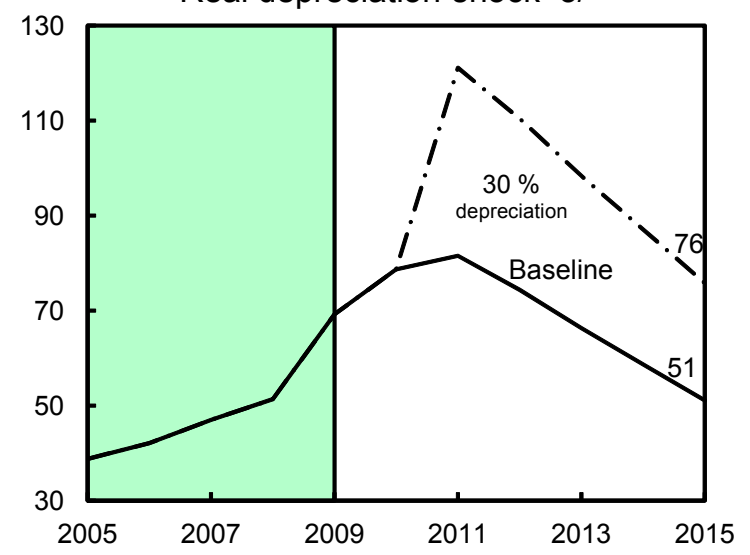

Sources: International Monetary Fund, Country desk data, and staff estimates.

$1 /$ Shaded areas represent actual data. Individual shocks are permanent one-half standard deviation shocks. Figures in the boxes represent average projections for the respective variables in the baseline and scenario being presented. Ten-year historical average for the variable is also shown.

2/ Permanent 1/4 standard deviation shocks applied to real interest rate, growth rate, and current account balance.

3/ One-time real depreciation of 30 percent occurs in 2010. 
Table 1. Romania: Quantitative Program Targets

\begin{tabular}{|c|c|c|c|c|c|c|c|c|c|c|c|c|}
\hline & \multirow{3}{*}{$\begin{array}{c}2008 \\
\text { Dec } \\
\text { Actual } \\
\end{array}$} & \multicolumn{4}{|c|}{2009} & \multicolumn{5}{|c|}{2010} & \multicolumn{2}{|c|}{2011} \\
\hline & & \multirow{2}{*}{$\begin{array}{l}\text { March } \\
\text { Actual } \\
\end{array}$} & \multirow{2}{*}{$\begin{array}{r}\text { June } \\
\text { Actual } \\
\end{array}$} & \multirow{2}{*}{$\begin{array}{r}\text { Sept } \\
\text { Actual } \\
\end{array}$} & \multirow{2}{*}{$\begin{array}{r}\text { Dec } \\
\text { Actual } \\
\end{array}$} & \multirow{2}{*}{$\begin{array}{l}\text { March } \\
\text { Actual }\end{array}$} & \multirow{2}{*}{$\begin{array}{r}\text { June } \\
\text { Actual } \\
\end{array}$} & \multicolumn{2}{|c|}{ Sept } & \multirow{2}{*}{$\begin{array}{l}\text { Dec } \\
\text { Prog. }\end{array}$} & \multirow{2}{*}{$\begin{array}{c}\text { January } \\
\text { Perf. crit. In }\end{array}$} & \multirow{2}{*}{$\begin{array}{r}\text { March } \\
\text { ndicative }\end{array}$} \\
\hline & & & & & & & & Prog. & Actual & & & \\
\hline \multicolumn{13}{|l|}{ I. Quantitative Performance Criteria } \\
\hline 1. Change in net foreign assets ( $\mathrm{mln}$ euros) $1 / 2 /$ & 25,532 & $-3,500$ & $-5,119$ & $-4,566$ & $-4,874$ & 779 & -509 & $-2,000$ & -318 & $-2,000$ & 0 & 350 \\
\hline 2. Floor on general government overall balance ( $\mathrm{mln}$ lei) $3 / 4 / 5$ / & $-24,655$ & $-8,300$ & $-14,456$ & $-25,563$ & $-36,101$ & $-8,422$ & $-18,015$ & 27,505 & 23,732 & $-34,650$ & & $-6,300$ \\
\hline 3. Stock in general government arrears (bn lei) & 1.06 & 1.41 & 1.55 & 1.4 & 1.50 & 1.76 & 1.8 & 0.81 & 1.57 & 0.48 & & 0 \\
\hline 4. Ceiling on general government guarantees issued since start of program (face value, bn & $\ldots$ & $\ldots$ & 0.02 & 0.8 & 2.2 & 4.6 & 5.5 & 12.0 & 6.5 & 12.0 & & 12.0 \\
\hline \multicolumn{13}{|l|}{ II. Continuous Performance Criterion } \\
\hline '5. Nonaccumulation of external debt arrears & 0 & 0 & 0 & 0 & 0 & 0 & 0 & 0 & 0 & 0 & & 0 \\
\hline \multicolumn{13}{|l|}{ III. Inflation Consultation } \\
\hline Outer band (upper limit) & $\ldots$ & $\ldots$ & 8.4 & 7.7 & 6.5 & $6.5^{\mathrm{F}}$ & 6.0 & 10.0 & $\ldots$ & 10.0 & & 9.0 \\
\hline Inner band (upper limit) & $\ldots$ & $\ldots$ & 7.4 & 6.7 & 5.5 & $5.5^{\mathrm{F}}$ & 5.0 & 9.0 & $\ldots$ & 9.0 & & 8.0 \\
\hline Actual/Center point & 6.3 & 6.7 & 5.9 & 4.8 & 4.7 & 4.2 & 4.4 & 8.0 & 7.8 & 8.0 & & 7.0 \\
\hline Inner band (lower limit) & $\ldots$ & $\ldots$ & 5.4 & 4.7 & 3.5 & $3.5^{\circ}$ & 3.0 & 7.0 & $\ldots$ & 7.0 & & 6.0 \\
\hline Outer band (lower limit) & $\ldots$ & $\ldots$ & 4.4 & 3.7 & 2.5 & $2.5^{\prime}$ & 2.0 & 6.0 & $\ldots$ & 6.0 & & 5.0 \\
\hline \multicolumn{13}{|l|}{ IV. Indicative Target } \\
\hline 17. General government current primary spending (excl. EU funds and social assistance, mlt & 92,327 & 22,149 & 43,238 & 63,878 & 85,637 & 32,749 & 66,124 & 100,000 & 98,721 & 131,500 & & 32,200 \\
\hline $\begin{array}{l}\text { 8. Operating balance (earnings before interest and tax) net of subsidies of } 10 \text { SOEs, } \\
\text { defined in TMU (mln. lei) } 3 /\end{array}$ & & & & & & $-1,081$ & $-2,333$ & $-3,000$ & $-3,801$ & $-4,000$ & & -750 \\
\hline \multicolumn{13}{|l|}{ Memorandum Item: } \\
\hline Revenue of general government, net of EU funds (mln. lei) 3/ & $\ldots$ & $\ldots$ & $\ldots$ & $\ldots$ & 151,508 & 36,355 & 74,669 & 114,700 & 116,091 & 157,950 & & 40,100 \\
\hline
\end{tabular}

1/ The December 2008 figure is a stock.

2/ Performance criterion for January 2011 and indicative target for March 2011 are relative to December 2010 target.

3/ Cumulative figure during calendar year (e.g. March 2011 figure is cumulative from January 1, 2011).

4/ In accordance with TMU, the end-September program target was adjusted from the original target of -28,200 by one-half of the revenue over-performance.

5/ The target for March 2011 can be adjusted with higher or lower capital spending as defined in TMU. 
Table 2. Romania: Performance for Sixth Review and Proposed New Conditionality

Measure
Prior actions
1. Parliamentary approval of the agreed 2011 budget, including ratification of the
24 percent VAT rate
5. Ensuring central government and social security arrears at near zero at end-
November 2010
3. Approval of the unified public wage legislation
4. Enactment of the pension reform
5. Amending ordinance on credit contracts so that it improves transparency and
protects consumer rights while safeguarding the stability of the financial
system.

\section{Quantitative performance criteria}

1. Floor on net foreign assets

2. Floor on general government overall balance

3. Ceiling on general government guarantees

4. Ceiling on general government domestic arrears

5. Non-accumulation of external debt arrears

\section{Quantitative Indicative Target}

1. Ceiling on general government current primary spending

"2. An indicative target on the operating balance of ten largest loss-making SOEs

Inner band

Outer band

\section{Structural benchmarks}

1. Approval of reforms to mitigate fiscal risks from local governments

2. Reform of the DGF's funding regime through increase in bank's contribution rates and elimination of stand-by credit lines, and review of DGF governance arrangement

3 Parliamentary ratification of the fiscal measures approved by the government

44 Passage of framework and implementing legislation for the unified wage law

"5 Reform tax administration methodology for high net wealth individuals

'6 Parliamentary ratification of amendments to the bank resolution framework

7. Parliamentary approval of agreed 2011 budget

"8. Amend deposit insurance legislation to ensure that neither members of the board nor employees of credit institutions participate in the DGF Board

'9. First phase to integrate the accounting reporting system with the Treasury payment system
September, 2010

September, 2010

September, 2010

September, 2010

September, 2010

September, 2010

September, 2010

September, 2010

September, 2010

\author{
Met \\ Met \\ Met \\ Missed \\ Met
}

\section{Met}

Missed

Met

Met

September 30, 2010 Met in June 2010

September 30, 2010 Met; the reform of the governance arrangement modified to endDecember 2010

September 30, 2010 Partially met, VAT ratification reset as prior

October 31, 2010 Not met, reset as prior action

November 30, 2010 Reset to December 31, 2010

December 1, 2010

December 15, 2010

December 31, 2010

Partially met

Reset as prior action

March 31, 2011

Modified and reset for March 15, 2011

\section{Proposed structural benchmarks}

10. Amend legislation to allow the use of the deposit guarantee fund resources to March 15, 2011 facilitate bank restructuring, including purchase and assumption transactions 
Table 3. Romania: Selected Economic and Social Indicators, 2008-15

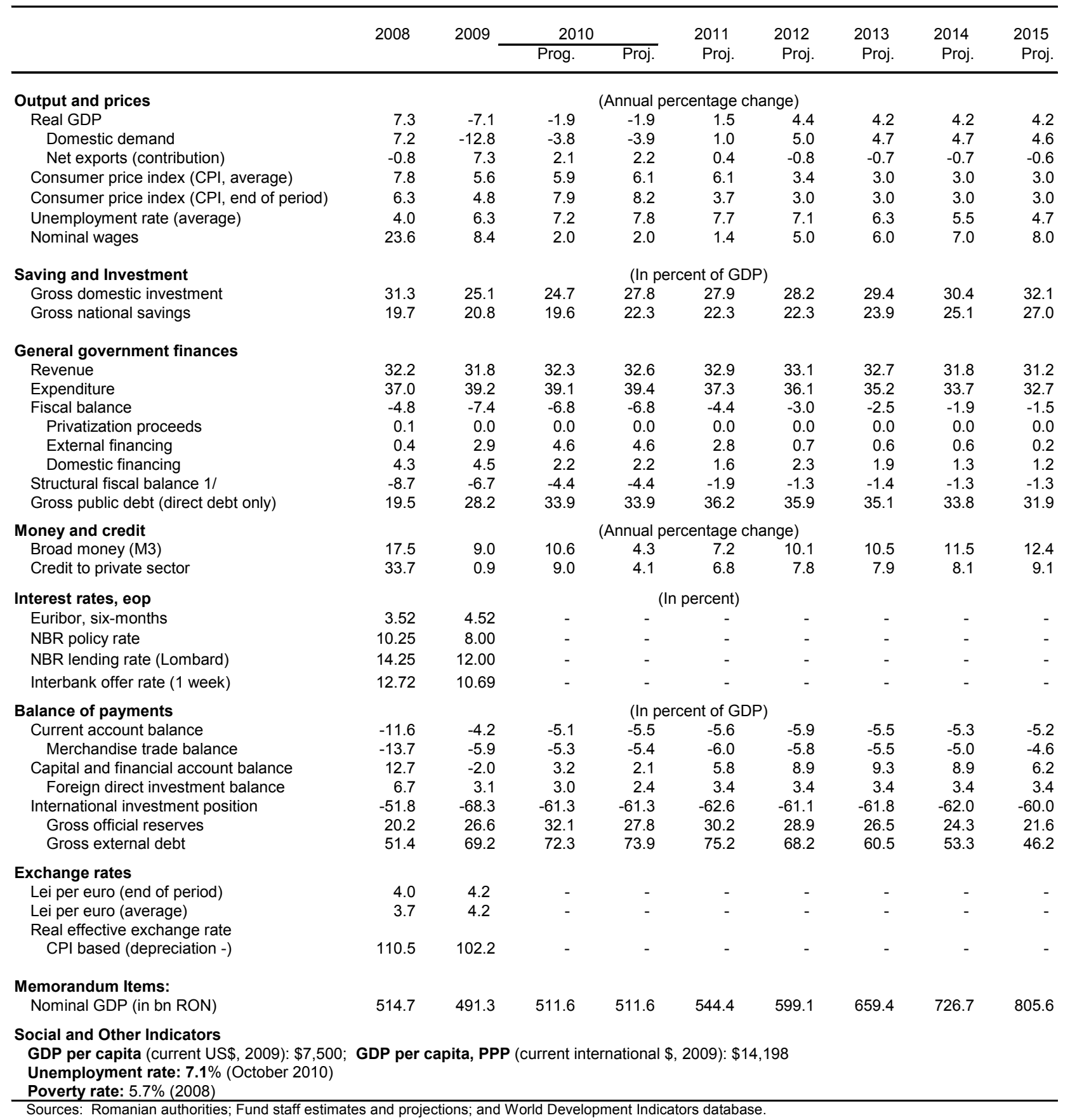

$1 /$ Actual fiscal balance adjusted for the automatic effects of the business cycle. 
Table 4. Romania: Balance of Payments, 2008-15 (In billions of euros, unless otherwise indicated)

\begin{tabular}{|c|c|c|c|c|c|c|c|c|c|}
\hline & \multirow{2}{*}{$\begin{array}{l}2008 \\
\text { Act }\end{array}$} & \multirow{2}{*}{$\begin{array}{r}2009 \\
\text { Act }\end{array}$} & \multicolumn{2}{|c|}{2010} & \multirow{2}{*}{$\begin{array}{l}2011 \\
\text { Proj. }\end{array}$} & \multirow{2}{*}{$\begin{array}{l}2012 \\
\text { Proj. }\end{array}$} & \multirow{2}{*}{$\begin{array}{l}2013 \\
\text { Proj. }\end{array}$} & \multirow{2}{*}{$\begin{array}{l}2014 \\
\text { Proj. }\end{array}$} & \multirow{2}{*}{$\begin{array}{r}2015 \\
\text { Proj. }\end{array}$} \\
\hline & & & Prog & Proj & & & & & \\
\hline Current account balance & -16.2 & -4.9 & -6.2 & -6.7 & -7.2 & -8.5 & -8.8 & -9.6 & -10.6 \\
\hline Merchandise trade balance & -19.1 & -6.9 & -6.5 & -6.5 & -7.6 & -8.4 & -8.8 & -9.1 & -9.4 \\
\hline Exports (f.o.b.) & 33.7 & 29.1 & 35.4 & 35.2 & 37.4 & 41.1 & 45.4 & 50.3 & 55.5 \\
\hline Imports (f.o.b.) & 52.8 & 36.0 & 41.9 & 41.7 & 45.0 & 49.5 & 54.2 & 59.4 & 64.8 \\
\hline Services balance & 0.7 & -0.7 & -0.1 & -0.8 & -0.9 & -1.0 & -1.1 & -1.0 & -1.0 \\
\hline Exports of non-factor services & 8.8 & 7.6 & 7.3 & 6.3 & 6.7 & 7.4 & 8.2 & 9.0 & 10.0 \\
\hline Imports of non-factor services & 8.1 & 8.3 & 7.4 & 7.1 & 7.7 & 8.4 & 9.2 & 10.1 & 11.0 \\
\hline Income balance & -3.7 & -1.5 & -2.5 & -2.2 & -2.4 & -2.7 & -3.1 & -3.6 & -4.2 \\
\hline Receipts & 2.3 & 0.7 & 1.5 & 1.0 & 1.0 & 1.1 & 1.1 & 1.2 & 1.2 \\
\hline Payments & 6.0 & 2.2 & 3.9 & 3.2 & 3.4 & 3.8 & 4.3 & 4.8 & 5.4 \\
\hline Current transfer balance & 6.0 & 4.2 & 2.8 & 2.8 & 3.7 & 3.6 & 4.2 & 4.2 & 4.0 \\
\hline Capital and financial account balance & 17.8 & -2.3 & 3.9 & 2.5 & 7.5 & 12.7 & 14.9 & 16.0 & 12.7 \\
\hline Capital account balance & 0.6 & 0.6 & 0.4 & 0.6 & 0.6 & 0.6 & 0.6 & 0.6 & 0.6 \\
\hline Foreign direct investment balance & 9.3 & 3.5 & 3.6 & 2.9 & 4.4 & 4.9 & 5.5 & 6.2 & 7.0 \\
\hline Portfolio investment balance & -0.9 & 0.5 & 2.2 & 0.9 & 2.0 & 1.8 & 2.7 & 2.6 & -1.0 \\
\hline Other investment balance & 8.7 & -6.9 & -2.3 & -1.9 & 0.5 & 5.4 & 6.1 & 6.7 & 6.2 \\
\hline General government 1/ & 0.2 & -0.3 & 2.1 & -0.2 & -0.3 & 0.0 & 0.0 & -0.2 & -1.5 \\
\hline Domestic banks & 3.0 & -5.4 & -0.6 & -0.3 & 0.0 & 1.2 & 1.3 & 1.5 & 1.7 \\
\hline Other private sector & 5.5 & -1.3 & -3.9 & -1.4 & 0.8 & 4.3 & 4.8 & 5.3 & 6.0 \\
\hline Errors and omissions & -1.7 & -1.0 & 0.0 & 0.0 & 0.0 & 0.0 & 0.0 & 0.0 & 0.0 \\
\hline Prospective financing & $\ldots$ & 2.1 & 4.4 & 2.9 & 2.6 & & & & \\
\hline European Commission & $\ldots$ & 1.5 & 3.4 & 2.2 & 1.4 & & & & \\
\hline World Bank & $\ldots$ & 0.3 & 0.4 & 0.0 & 0.7 & & & & \\
\hline EIB/EBRD & $\ldots$ & 0.3 & 0.7 & 0.7 & 0.5 & & & & \\
\hline Overall balance & 0.0 & -6.1 & 2.1 & -1.3 & 2.9 & 4.3 & 6.1 & 6.4 & 2.2 \\
\hline Financing & 0.0 & 6.1 & -2.1 & 1.3 & -2.9 & -4.3 & -6.1 & -6.4 & -2.2 \\
\hline Gross international reserves (increase: -) & 0.0 & -2.1 & -5.6 & -3.0 & -4.8 & -2.7 & -1.2 & -1.3 & -0.1 \\
\hline Use of Fund credit, net & 0.0 & 6.8 & 5.1 & 4.3 & 1.9 & -1.6 & -4.9 & -5.2 & -2.0 \\
\hline Purchases $2 /$ & 0.0 & 6.8 & 5.1 & 4.3 & 1.9 & 0.0 & 0.0 & 0.0 & 0.0 \\
\hline Repurchases & 0.0 & 0.0 & 0.0 & 0.0 & 0.0 & -1.6 & -4.9 & -5.2 & -2.0 \\
\hline Other liabilities, net $3 /$ & 0.0 & 1.0 & 0.0 & 0.0 & 0.0 & 0.0 & 0.0 & 0.0 & 0.0 \\
\hline Memorandum items: & \multicolumn{9}{|c|}{ (In percent of GDP) } \\
\hline Current account balance & -11.6 & -4.2 & -5.1 & -5.5 & -5.6 & -5.9 & -5.5 & -5.3 & -5.2 \\
\hline Foreign direct investment balance & 6.7 & 3.1 & 3.0 & 2.4 & 3.4 & 3.4 & 3.4 & 3.4 & 3.4 \\
\hline Merchandise trade balance & -13.7 & -5.9 & -5.3 & -5.4 & -6.0 & -5.8 & -5.5 & -5.0 & -4.6 \\
\hline Exports & 24.1 & 25.1 & 29.2 & 28.9 & 29.2 & 28.7 & 28.2 & 27.8 & 27.2 \\
\hline Imports & 37.8 & 31.0 & 34.6 & 34.3 & 35.2 & 34.5 & 33.7 & 32.9 & 31.8 \\
\hline Gross external financing requirement & 32.9 & 30.3 & 28.2 & 27.9 & 27.3 & 25.7 & 24.0 & 22.7 & 21.4 \\
\hline & \multicolumn{9}{|c|}{ (Annual percentage change) } \\
\hline Terms of trade (merchandise) & 3.1 & 0.2 & -2.8 & -5.2 & -3.4 & -0.4 & 1.1 & 1.4 & 1.1 \\
\hline Merchandise export volume & 3.8 & -3.3 & 7.9 & 21.2 & 4.7 & 8.9 & 7.7 & 7.9 & 8.1 \\
\hline Merchandise import volume & 4.7 & -23.8 & 2.6 & 11.1 & 2.9 & 8.4 & 8.1 & 8.1 & 8.1 \\
\hline Merchandise export prices & 20.9 & 2.9 & 12.8 & -0.2 & 1.6 & 1.0 & 2.7 & 2.9 & 2.3 \\
\hline Merchandise import prices & 17.2 & 2.7 & 13.8 & 5.1 & 5.0 & 1.4 & 1.5 & 1.5 & 1.2 \\
\hline & \multicolumn{9}{|c|}{ (In billions of euros) } \\
\hline Gross international reserves $3 /$ & 28.3 & 30.9 & 38.9 & 33.9 & 38.7 & 41.4 & 42.6 & 43.9 & 44.0 \\
\hline GDP & 139.7 & 116.0 & 121.1 & 121.9 & 128.1 & 143.4 & 160.7 & 180.6 & 204.0 \\
\hline
\end{tabular}

Sources: Romanian authorities; and Fund staff estimates and projections.

$1 /$ Includes IMF disbursement to the Treasury of $€ 0.9$ billion in 2009 and $€ 1.2$ billion in 2010, and issuance of $€ 1$ billion Eurobond $1 /$ Revisions to the 2004 data since the May 2004 Board meeting have led to a deterioration of about 0.8 percent of GDP. of an Euro bond of $€ 1$ billion in 2010 .

2/ IMF disbursements amounted to $€ 6.8$ billion in 2009 and are projected to amount to $€ 5$ billion in 2010 Of these $€ 0.9$ billion in 2009 , and $€ 1.2$ billion in 2010 have been disbursed directly to the Treasury,

included in the capital and financial account as noted in footnote 1.

3/ Operational defition. Reflects the allocation of SDR 908.8 million that was made avaialable in two tranches in August and September 2009. 
Table 5. Romania: Gross Financing Requirements, 2009-11 (In billions of euros, unless otherwise indicated)

\begin{tabular}{|c|c|c|c|c|c|c|c|c|c|c|c|c|}
\hline & \multicolumn{5}{|c|}{2009} & \multicolumn{5}{|c|}{2010} & \multirow{2}{*}{$\begin{array}{l}2011 \\
\text { Year }\end{array}$} & \multirow{2}{*}{$\begin{array}{c}\text { Total } \\
2009-11\end{array}$} \\
\hline & Q1 & Q2 & Q3 & Q4 & Year & Q1 & Q2 & Q3 & Q4 & Year & & \\
\hline & Act & Act & Act & Act & Act & Act & Act & Proj & Proj & Proj. & Proj. & \\
\hline I. Total financing requirements & 12.5 & 15.7 & 10.8 & 8.8 & 47.9 & 10.3 & 7.9 & 7.6 & 9.2 & 35.0 & 32.9 & 115.8 \\
\hline I.A. Current account deficit & 0.4 & 1.8 & 0.9 & 1.7 & 4.9 & 1.6 & 2.2 & 0.4 & 2.5 & 6.7 & 7.2 & 18.8 \\
\hline I.B. Short-term debt & 9.2 & 10.4 & 6.4 & 4.7 & 30.7 & 4.9 & 4.0 & 4.6 & 4.6 & 18.1 & 17.4 & 66.2 \\
\hline Public sector & 2.8 & 4.1 & 0.9 & 1.0 & 8.8 & 1.4 & 0.6 & 0.6 & 0.7 & 3.3 & 2.8 & 14.9 \\
\hline Banks & 3.6 & 4.6 & 4.0 & 2.2 & 14.4 & 2.6 & 2.7 & 2.6 & 2.7 & 10.6 & 9.8 & 34.8 \\
\hline Corporates & 2.8 & 1.7 & 1.5 & 1.5 & 7.5 & 0.9 & 0.7 & 1.4 & 1.2 & 4.2 & 4.8 & 16.5 \\
\hline I.C. Maturing medium- and long-term debt & 1.8 & 3.0 & 1.6 & 3.5 & 9.9 & 2.9 & 1.8 & 3.5 & 2.6 & 10.8 & 8.8 & 29.5 \\
\hline Public sector & 0.2 & 0.3 & 0.2 & 0.3 & 1.0 & 0.2 & 0.3 & 0.9 & 0.2 & 1.6 & 0.9 & 3.5 \\
\hline Banks & 0.8 & 1.6 & 0.4 & 1.9 & 4.7 & 1.1 & 0.5 & 1.0 & 0.6 & 3.2 & 2.6 & 10.5 \\
\hline Corporates & 0.8 & 1.1 & 1.0 & 1.3 & 4.2 & 1.6 & 1.0 & 1.6 & 1.8 & 6.0 & 5.3 & 15.5 \\
\hline I.D. Other net capital outflows $1 /$ & 1.1 & 0.5 & 1.9 & -1.1 & 2.4 & 0.9 & -0.1 & -0.9 & -0.5 & -0.6 & -0.5 & 1.3 \\
\hline II. Total financing sources & 11.0 & 12.3 & 9.7 & 7.9 & 40.9 & 9.0 & 7.5 & 6.6 & 7.4 & 30.6 & 33.1 & 104.6 \\
\hline II.A. Foreign direct investment, net & 1.6 & 1.1 & 0.7 & 0.1 & 3.6 & 0.5 & 0.8 & 0.6 & 1.0 & 2.9 & 4.4 & 10.8 \\
\hline II.B. Capital account inflows & 0.0 & 0.1 & 0.2 & 0.4 & 0.6 & 0.0 & 0.1 & 0.2 & -0.1 & 0.2 & 0.1 & 0.9 \\
\hline II.C. Short-term debt & 7.2 & 7.4 & 5.1 & 4.9 & 24.6 & 6.0 & 4.7 & 4.1 & 4.1 & 18.9 & 18.1 & 61.6 \\
\hline Public sector & 3.7 & 3.1 & 1.1 & 1.3 & 9.2 & 1.7 & 0.8 & 0.2 & 0.1 & 2.8 & 2.8 & 14.9 \\
\hline Banks & 2.4 & 3.4 & 2.6 & 2.4 & 10.8 & 3.0 & 2.6 & 2.9 & 2.8 & 11.3 & 9.8 & 31.9 \\
\hline Corporates & 1.1 & 0.9 & 1.4 & 1.2 & 4.6 & 1.3 & 1.3 & 1.0 & 1.2 & 4.8 & 5.5 & 14.9 \\
\hline II.D. Medium- and long-term debt & 2.2 & 3.7 & 3.6 & 2.6 & 12.1 & 2.5 & 1.9 & 1.7 & 2.4 & 8.5 & 10.6 & 31.2 \\
\hline Public sector $2 /$ & 0.0 & 0.2 & 0.1 & 0.5 & 0.8 & 1.1 & 0.2 & 0.2 & 0.8 & 2.3 & 2.6 & 5.7 \\
\hline Banks & 0.8 & 2.0 & 1.8 & 0.8 & 5.4 & 0.4 & 1.1 & 0.2 & 0.5 & 2.2 & 2.6 & 10.2 \\
\hline Corporates & 1.4 & 1.5 & 1.7 & 1.3 & 5.9 & 1.0 & 0.6 & 1.3 & 1.1 & 4.0 & 5.4 & 15.3 \\
\hline III. Increase in gross reserves & -2.0 & 1.8 & 1.9 & 0.3 & 2.0 & 2.9 & -0.9 & 2.5 & -1.5 & 3.0 & 4.8 & 9.8 \\
\hline IV. Errors and omissions & 0.2 & -0.1 & -1.3 & -0.1 & -1.3 & 0.6 & -0.7 & 0.3 & 0.0 & 0.3 & 0.0 & -1.0 \\
\hline V. Program financing & 0.0 & 4.9 & 3.5 & 0.5 & 8.9 & 3.6 & 0.2 & 3.2 & 0.3 & 7.2 & 4.5 & 20.6 \\
\hline IMF & 0.0 & 4.9 & 1.9 & 0.0 & 6.8 & 2.5 & 0.0 & 1.9 & 0.0 & 4.3 & 1.9 & 13.1 \\
\hline Others & 0.0 & 0.0 & 1.6 & 0.5 & 2.1 & 1.2 & 0.2 & 1.3 & 0.3 & 2.9 & 2.6 & 7.5 \\
\hline European Commission & 0.0 & 0.0 & 1.5 & 0.0 & 1.5 & 1.0 & 0.0 & 1.2 & 0.0 & 2.2 & 1.4 & 5.0 \\
\hline World Bank & 0.0 & 0.0 & 0.0 & 0.3 & 0.3 & 0.0 & 0.0 & 0.0 & 0.0 & 0.0 & 0.7 & 1.0 \\
\hline EIB/EBRD & 0.0 & 0.0 & 0.1 & 0.2 & 0.3 & 0.2 & 0.2 & 0.2 & 0.3 & 0.7 & 0.5 & 1.5 \\
\hline VI. Other Financing $3 /$ & 0.0 & 0.0 & 1.0 & 0.0 & 1.0 & 0.0 & 0.0 & 0.0 & 0.0 & 0.0 & 0.0 & 1.0 \\
\hline \multicolumn{13}{|l|}{ Memorandum items: } \\
\hline \multicolumn{13}{|l|}{ Rollover rates for amortizing debt (in percent) } \\
\hline Public sector & & & 100 & 100 & 102 & 96 & 111 & 30 & 102 & 106 & 106 & \\
\hline Banks & 72 & 87 & 100 & 77 & 84 & 92 & 116 & 86 & 100 & 98 & 100 & $\ldots$ \\
\hline Corporates & 69 & 86 & 124 & 89 & 90 & 92 & 112 & 77 & 77 & 86 & 108 & $\ldots$ \\
\hline Gross international reserves $3 /$ & 27.4 & 28.7 & 30.6 & 30.9 & 30.9 & 33.8 & 32.9 & 35.4 & 33.9 & 33.9 & 38.7 & $\ldots$ \\
\hline \multicolumn{13}{|l|}{ Coverage of gross international reserves } \\
\hline - Months of imports of GFNS (next year) & $\ldots$ & $\ldots$ & $\ldots$ & $\ldots$ & 7.5 & $\ldots$ & $\ldots$ & $\ldots$ & $\ldots$ & 8.6 & 8.0 & $\ldots$ \\
\hline - Short-term external debt (in percent) & 92 & 103 & 109 & 107 & 107 & 120 & 113 & 133 & 130 & 130 & 133 & $\ldots$ \\
\hline
\end{tabular}
Source: IMF staff estimates.

$1 /$ Includes includes portfolio equity, financial derivatives and other investments, assets position.

2/ Excludes the disbursements by the IMF directly to the Treasury, amounting to $€ 0.9$ billion in 2009Q3 and €0.8 billion in 2009Q4.

3/ Operational defition. Reflects two SDR allocations in August and September 2009. 
Table 6. Romania: General Government Operations, 2007-12 (In percent of GDP)

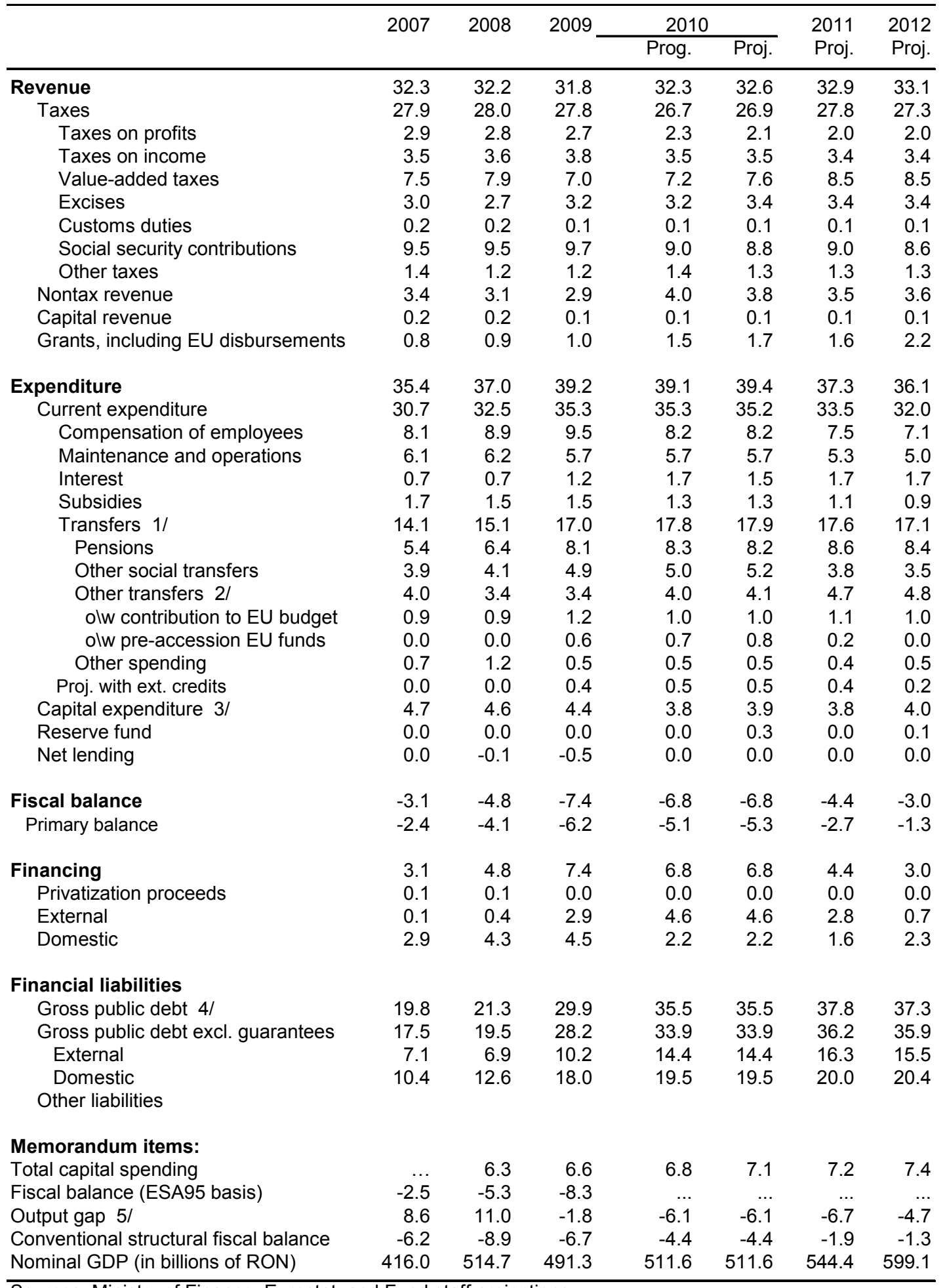

Sources: Ministry of Finance; Eurostat; and Fund staff projections.

1 / Increase in 2009 mostly reflects higher EU-financed capital spending and budgeted rise in pensions.

2/ Includes co-financing of EU projects.

3/ Does not include all capital spending.

4/ Total public debt, including government debt, local government debt, and guarantees.

5/ Percentage deviation of actual from potential GDP. 
Table 6. Romania: General Government Operations, 2007-12 (concluded)

(In millions of RON)

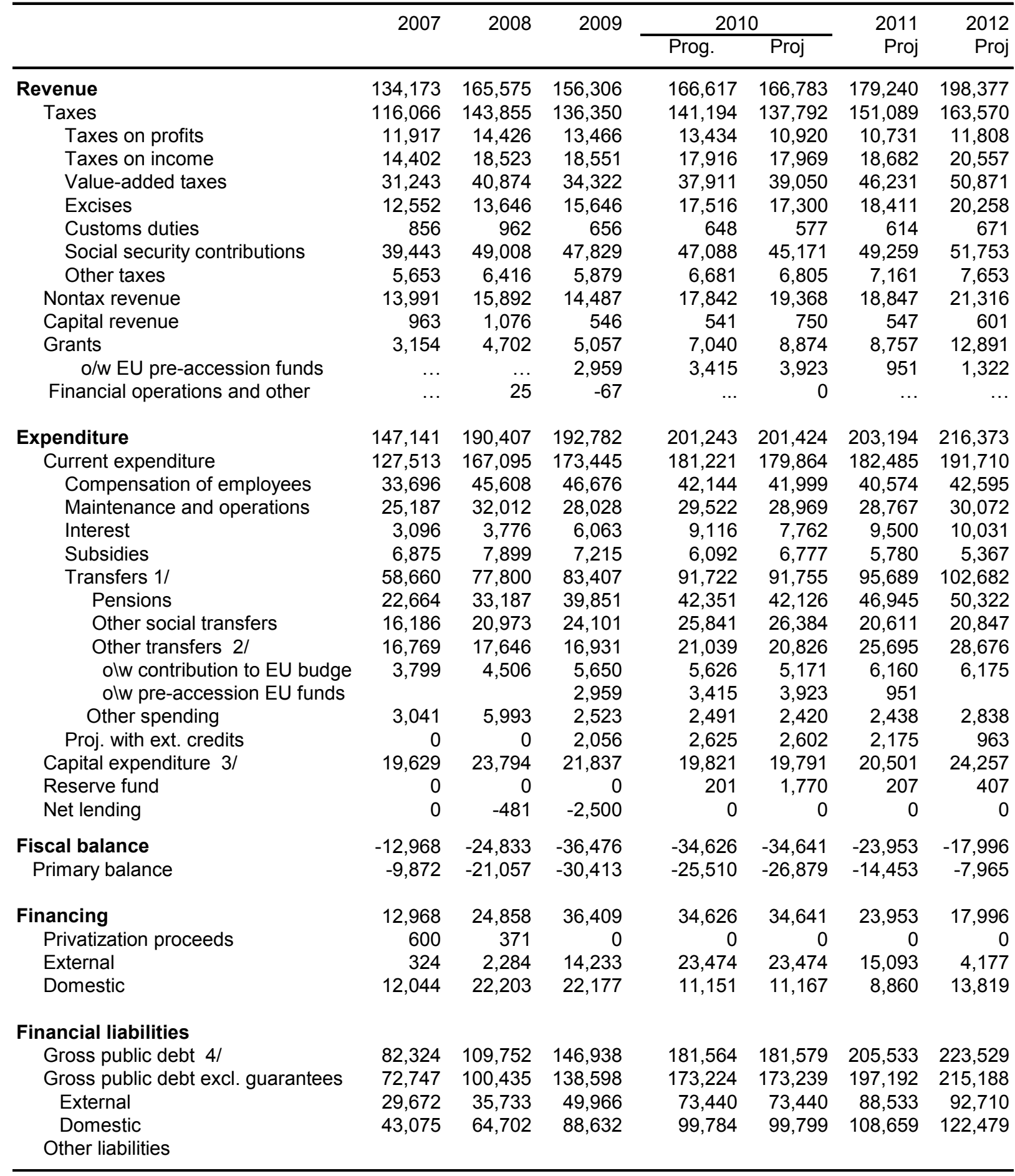

Sources: Ministry of Finance; Eurostat; and Fund staff projections.

1/ Increase in 2009 mostly reflects higher EU-financed capital spending and budgeted rise in pensions.

2/ Includes co-financing of EU projects.

3/ Does not include all capital spending.

4/ Total public debt, including government debt, local government debt, and guarantees. 
Table 7. Romania: Monetary Survey, 2007-11 (In millions of lei (RON), unless otherwise indicated; end of period)

\begin{tabular}{|c|c|c|c|c|c|}
\hline & Dec-07 & Dec-08 & Dec-09 & $\begin{array}{l}\text { Dec-10 } \\
\text { Proj. 2/ }\end{array}$ & $\begin{array}{r}\text { Dec-11 } \\
\text { Proj. }\end{array}$ \\
\hline \multicolumn{6}{|c|}{ I. Banking System } \\
\hline $\begin{array}{l}\text { Net foreign assets } \\
\text { In million euros } \\
\text { o/w commercial banks }\end{array}$ & $\begin{array}{r}29,070 \\
8,052 \\
-18,668\end{array}$ & $\begin{array}{r}13,138 \\
3,297 \\
-24,386\end{array}$ & $\begin{array}{r}17,684 \\
4,182 \\
-19,708\end{array}$ & $\begin{array}{r}28,914 \\
6,734 \\
-19,408\end{array}$ & $\begin{array}{r}38,635 \\
9,164 \\
-19,408\end{array}$ \\
\hline $\begin{array}{l}\text { Net domestic assets } \\
\text { Public sector credit } \\
\text { Private sector credit } \\
\text { Other }\end{array}$ & $\begin{array}{r}119,046 \\
9,571 \\
148,181 \\
-38,706\end{array}$ & $\begin{array}{r}160,890 \\
17,268 \\
198,086 \\
-54,464\end{array}$ & $\begin{array}{r}171,946 \\
46,811 \\
199,887 \\
-74,752\end{array}$ & $\begin{array}{r}168,778 \\
57,991 \\
208,039 \\
-97,252\end{array}$ & $\begin{array}{r}173,369 \\
77,677 \\
222,187 \\
-126,495\end{array}$ \\
\hline $\begin{array}{l}\text { Broad Money (M3) } \\
\text { Intermediate money (M2) } \\
\text { Money market instruments } \\
\text { Narrow money (M1) } \\
\text { Currency in circulation } \\
\text { Overnight deposits }\end{array}$ & $\begin{array}{r}148,116 \\
148,044 \\
72 \\
79,914 \\
21,442 \\
58,472\end{array}$ & $\begin{array}{r}174,028 \\
173,629 \\
399 \\
92,549 \\
25,287 \\
67,262\end{array}$ & $\begin{array}{r}189,630 \\
188,013 \\
1,617 \\
79,361 \\
23,968 \\
55,394\end{array}$ & $\begin{array}{r}197,692 \\
194,592 \\
3,100 \\
91,002 \\
25,281 \\
65,721\end{array}$ & $\begin{array}{r}212,004 \\
208,680 \\
3,324 \\
106,806 \\
27,272 \\
79,534\end{array}$ \\
\hline \multicolumn{6}{|c|}{ II. National Bank of Romania } \\
\hline $\begin{array}{l}\text { Net foreign assets } \\
\text { In million euros }\end{array}$ & $\begin{array}{l}96,466 \\
26,720\end{array}$ & $\begin{array}{r}110,323 \\
27,683\end{array}$ & $\begin{array}{r}101,015 \\
23,891\end{array}$ & $\begin{array}{r}113,616 \\
25,715\end{array}$ & $\begin{array}{r}113,865 \\
28,572\end{array}$ \\
\hline $\begin{array}{l}\text { Net domestic assets } \\
\text { Public sector credit, net } \\
\text { Credit to banks, net } \\
\text { Other }\end{array}$ & $\begin{array}{r}-47,593 \\
-8,499 \\
-41,168 \\
2,074\end{array}$ & $\begin{array}{r}-59,855 \\
-1,428 \\
-51,126 \\
-7,301\end{array}$ & $\begin{array}{l}-49,354 \\
-13,626 \\
-23,848 \\
-11,879\end{array}$ & $\begin{array}{l}-64,968 \\
-13,626 \\
-35,735 \\
-15,606\end{array}$ & $\begin{array}{l}-62,284 \\
-13,626 \\
-33,052 \\
-15,606\end{array}$ \\
\hline Reserve money & 48,873 & 50,468 & 51,662 & 48,648 & 51,581 \\
\hline \multicolumn{6}{|c|}{ (Annual percentage change) } \\
\hline Broad money (M3) & 33.7 & 17.5 & 9.0 & 4.3 & 7.2 \\
\hline NFA contribution & -8.7 & -10.8 & 2.6 & 5.9 & 4.9 \\
\hline NDA contribution & 42.4 & 28.3 & 6.4 & -1.7 & 2.3 \\
\hline Reserve money & 41.3 & 3.3 & 2.4 & -5.8 & 6.0 \\
\hline NFA contribution & 58.5 & 28.4 & -18.4 & 24.4 & 0.5 \\
\hline NDA contribution & -17.1 & -25.1 & 20.8 & -30.2 & 5.5 \\
\hline Domestic credit, real & 54.3 & 28.4 & 9.3 & -0.3 & 12.3 \\
\hline Private sector, at constant $\mathrm{e} / \mathrm{r}$ & 46.6 & 19.0 & -7.0 & -4.8 & 8.0 \\
\hline Public sector, real & 153.2 & 69.7 & 158.8 & 14.5 & 33.4 \\
\hline Broad money (M3), in real terms & 25.4 & 10.5 & 4.0 & -3.6 & 6.8 \\
\hline Private deposits, at constant e/r & 30.9 & 13.5 & 8.4 & 2.8 & 7.6 \\
\hline \multicolumn{6}{|l|}{ Memorandum items: } \\
\hline CPI inflation, eop & 6.6 & 6.3 & 4.8 & 8.2 & 3.7 \\
\hline Inflation target & $3-5$ & $2.8-4.8$ & $2.5-4.5$ & $2.5-4.5$ & $2.0-4.0$ \\
\hline \multicolumn{6}{|l|}{ Interest rates (percent): } \\
\hline Policy interest rate & 7.50 & 10.25 & 8.00 & 6.25 & $\ldots$ \\
\hline Interbank offer rate, 1 week & 7.81 & 13.90 & 10.70 & 4.9 & $\ldots$ \\
\hline Corporate loans $1 /$ & 11.6 & 19.5 & 15.4 & 10.9 & $\ldots$ \\
\hline Household time deposits $1 /$ & 6.9 & 15.3 & 9.9 & 7.5 & $\ldots$ \\
\hline Share of foreign currency private deposit & 32.1 & 34.8 & 38.8 & 37.0 & ... \\
\hline Share of foreign currency private loans & 54.3 & 57.8 & 60.1 & 60.4 & \\
\hline M2 velocity & 2.81 & 2.96 & 2.61 & 2.63 & 2.66 \\
\hline Money multiplier (M3/reserve money) & 3.03 & 3.45 & 3.67 & 4.06 & 4.11 \\
\hline
\end{tabular}

Sources: National Bank of Romania; and Fund staff estimates.

1/ Rates for new local currency denominated transactions.

2/ For interest rates and shares of foreign currency loans and deposits, latest available data. 
Table 8. Romania: Schedule of Reviews and Purchases

\begin{tabular}{lccl}
\hline \multicolumn{1}{c}{ Date } & \multicolumn{2}{c}{ Amount of Purchase } & \\
\cline { 2 - 3 } Millions of SDRs Percent of Quota & Conditions \\
\hline May 4, 2009 & 4,370 & 424.19 & Approval of arrangement \\
September 21, 2009 & 1,718 & 166.76 & First review and end-June 2009 performance criteria \\
December 15, 2009 1/ & 1,409 & 136.77 & Second review and end-September 2009 performance criteria \\
February 19, 2010 & 766 & 74.35 & Third review and end-December 2009 performance criteria \\
July 2, 2010 & 768 & 74.55 & Fourth review and end-March 2010 performance criteria \\
September 15, 2010 & 769 & 74.65 & Fifth review and end-June 2010 performance criteria \\
December 15, 2010 & 769 & 74.65 & Sixth review and end-September 2010 performance criteria \\
March 15, 2011 & 874 & 84.84 & Seventh review and end-December 2010 performance \\
criteria and end-January 2011 NFA performance criterion.
\end{tabular}

Source: IMF staff estimates.

$1 /$ The amount of purchase for the second review was available from December 15, 2009, but was made together with the amount for the third review on February 19, 2010 given the delay in completing the second review. 
Table 9. Romania: Indicators of Fund Credit, 2010-15 1/

(In millions of SDR)

2010

2011

2012

2013

2014

2015

\section{Existing Fund Credit}

Stock 2/

Obligations 3/

Repurchase

Charges

$\begin{array}{rrrrrr}9,800 & 9,800 & 8,493 & 4,441 & 848 & 0 \\ 0 & 136 & 1,442 & 4,154 & 3,635 & 855 \\ 0 & 0 & 1307 & 4052 & 3593 & 848 \\ 0 & 136 & 135 & 102 & 42 & 7\end{array}$

\section{Prospective Fund Credit under Stand-By Arrangement}

Disbursement

Stock 2/

Obligations $3 /$

Repurchase

Charges

\section{Stock of existing and prospective Fund credit}

In millions of SDR

In percent of quota

In percent of GDP

In percent of exports of goods and services

In percent of gross reserves

Obligations to the Fund from existing and prospective Fund arrangements

In millions of SDR

In percent of quota

In percent of GDP

In percent of exports of goods and services

In percent of gross reserves

$\begin{array}{rrrrrr}10,569 & 11,443 & 10,136 & 6,084 & 1,779 & 109 \\ 1,026 & 1,111 & 984 & 591 & 173 & 11 \\ 10.1 & 10.6 & 8.4 & 4.5 & 1.2 & 0.1 \\ 29.5 & 30.7 & 24.9 & 13.6 & 3.6 & 0.2 \\ 36.1 & 35.0 & 29.2 & 17.1 & 4.9 & 0.3 \\ & & & & & \\ 4 & 158 & 1,465 & 4,176 & 4,368 & 1,687 \\ 0.4 & 15.3 & 142.2 & 405.4 & 424.0 & 163.7 \\ 0.0 & 0.1 & 1.2 & 3.1 & 2.9 & 1.0 \\ 0.0 & 0.4 & 3.6 & 9.4 & 8.9 & 3.1 \\ 0.0 & 0.5 & 4.2 & 11.7 & 12.0 & 4.6\end{array}$

Source: IMF staff estimates.

1/ Using IMF actual disbursements, SDR interest rate as well as exchange rate of SDR/US\$ and US\$/€ of October $20,2010$.

2/ End of period.

3/ Repayment schedule based on repurchase obligations.

CInternational Monetary Fund. Not for Redistribution 
Table 10. Romania: Public Sector Debt Sustainability Framework, 2007-2015 (In percent of GDP, unless otherwise indicated)

\begin{tabular}{|c|c|c|c|c|c|c|c|c|c|c|}
\hline & \multicolumn{3}{|c|}{ Actual } & \multicolumn{6}{|c|}{ Projections } & \multirow{2}{*}{$\begin{array}{l}\text { Debt-stabilizing } \\
\text { primary }\end{array}$} \\
\hline & 2007 & 2008 & 2009 & 2010 & 2011 & 2012 & 2013 & 2014 & 2015 & \\
\hline $\begin{array}{l}\text { Baseline: Public sector debt } 1 / \\
\text { o/w foreign-currency denominated }\end{array}$ & $\begin{array}{r}17.5 \\
6.6\end{array}$ & $\begin{array}{r}19.5 \\
6.4\end{array}$ & $\begin{array}{l}28.2 \\
15.2\end{array}$ & $\begin{array}{l}33.9 \\
20.1\end{array}$ & $\begin{array}{l}36.2 \\
23.8\end{array}$ & $\begin{array}{l}35.9 \\
21.4\end{array}$ & $\begin{array}{l}35.1 \\
17.7\end{array}$ & $\begin{array}{l}33.8 \\
14.3\end{array}$ & $\begin{array}{l}31.9 \\
10.7\end{array}$ & -1.8 \\
\hline $\begin{array}{l}\text { Change in public sector debt } \\
\text { Identified debt-creating flows }\end{array}$ & $\begin{array}{r}2.1 \\
-0.5\end{array}$ & $\begin{array}{l}2.0 \\
2.4\end{array}$ & $\begin{array}{l}8.7 \\
8.3\end{array}$ & $\begin{array}{l}5.7 \\
5.7\end{array}$ & $\begin{array}{l}2.4 \\
2.4\end{array}$ & $\begin{array}{l}-0.3 \\
-0.3\end{array}$ & $\begin{array}{l}-0.8 \\
-0.8\end{array}$ & $\begin{array}{l}-1.4 \\
-1.4\end{array}$ & $\begin{array}{l}-1.8 \\
-1.8\end{array}$ & \\
\hline Primary deficit & 2.4 & 4.1 & 6.2 & 5.3 & 2.7 & 1.3 & 0.9 & 0.2 & -0.1 & \\
\hline Revenue and grants & 32.3 & 32.2 & 31.8 & 32.6 & 32.9 & 33.1 & 32.7 & 31.8 & 31.2 & \\
\hline Primary (noninterest) expenditure & 34.6 & 36.3 & 38.0 & 37.9 & 35.6 & 34.4 & 33.6 & 32.1 & 31.1 & \\
\hline Automatic debt dynamics $2 /$ & -2.3 & -1.3 & 2.1 & 0.4 & -0.3 & -1.6 & -1.7 & -1.6 & -1.7 & \\
\hline Contribution from interest rate/growth differential 3/ & -1.9 & -2.6 & 2.2 & 0.4 & -0.3 & -1.6 & -1.7 & -1.6 & -1.7 & \\
\hline Of which contribution from real interest rate & -1.1 & -1.6 & 0.7 & -0.1 & 0.2 & -0.2 & -0.3 & -0.3 & -0.4 & \\
\hline Of which contribution from real GDP growth & -0.8 & -1.0 & 1.5 & 0.5 & -0.5 & -1.5 & -1.4 & -1.4 & -1.3 & \\
\hline Contribution from exchange rate depreciation 4/ & -0.4 & 1.3 & 0.0 & $\ldots$ & $\ldots$ & $\ldots$ & $\ldots$ & $\ldots$ & $\ldots$ & \\
\hline Denominator & 1.2 & 1.2 & 1.0 & 1.0 & 1.1 & 1.1 & 1.1 & 1.1 & 1.1 & \\
\hline Other identified debt-creating flows & -0.6 & -0.4 & 0.0 & 0.0 & 0.0 & 0.0 & 0.0 & 0.0 & 0.0 & \\
\hline Privatization receipts (negative) & -0.6 & -0.4 & 0.0 & 0.0 & 0.0 & 0.0 & 0.0 & 0.0 & 0.0 & \\
\hline Recognition of implicit or contingent liabilities & 0.0 & 0.0 & 0.0 & 0.0 & 0.0 & 0.0 & 0.0 & 0.0 & 0.0 & \\
\hline Other (specify, e.g. bank recapitalization) & 0.0 & 0.0 & 0.0 & 0.0 & 0.0 & 0.0 & 0.0 & 0.0 & 0.0 & \\
\hline Residual, including asset changes $5 /$ & 2.1 & -0.6 & 0.4 & 0.0 & 0.0 & 0.0 & 0.0 & 0.0 & 0.0 & \\
\hline Public sector debt-to-revenue ratio $1 /$ & 54.2 & 60.7 & 88.6 & 103.9 & 110.0 & 108.5 & 107.4 & 106.0 & 102.4 & \\
\hline $\begin{array}{l}\text { Gross financing need 6/ } \\
\text { in billions of U.S. dollars }\end{array}$ & $\begin{array}{l}3.9 \\
6.7\end{array}$ & $\begin{array}{r}6.2 \\
12.7\end{array}$ & $\begin{array}{r}8.7 \\
14.1\end{array}$ & $\begin{array}{r}8.7 \\
13.9\end{array}$ & $\begin{array}{r}7.0 \\
11.4\end{array}$ & $\begin{array}{r}6.4 \\
11.8\end{array}$ & $\begin{array}{r}7.5 \\
15.3\end{array}$ & $\begin{array}{r}6.5 \\
14.9\end{array}$ & $\begin{array}{r}4.6 \\
11.7\end{array}$ & \\
\hline $\begin{array}{l}\text { Scenario with key variables at their historical averages } 7 / \\
\text { Scenario with no policy change (constant primary balance) in 2010- }\end{array}$ & 2015 & & & $\begin{array}{l}33.9 \\
33.9\end{array}$ & $\begin{array}{l}30.8 \\
38.7\end{array}$ & $\begin{array}{l}28.3 \\
42.2\end{array}$ & $\begin{array}{l}26.1 \\
45.4\end{array}$ & $\begin{array}{l}24.2 \\
48.5\end{array}$ & $\begin{array}{l}22.5 \\
51.2\end{array}$ & $\begin{array}{l}-2.9 \\
-2.9\end{array}$ \\
\hline \multicolumn{11}{|l|}{ Key Macroeconomic and Fiscal Assumptions Underlying Baseline } \\
\hline Nominal GDP (local currency) & 416.0 & 514.7 & 491.3 & 511.6 & 544.4 & 599.1 & 659.4 & 726.7 & 805.6 & \\
\hline Real GDP growth (in percent) & 6.3 & 7.3 & -7.1 & -1.9 & 1.5 & 4.4 & 4.2 & 4.2 & 4.2 & \\
\hline Average nominal interest rate on public debt (in percent) $8 /$ & 5.8 & 5.2 & 6.0 & 5.6 & 5.5 & 5.1 & 5.0 & 5.1 & 5.2 & \\
\hline Average nominal interest rate on forex debt (in percent) $6 /$ & 17.6 & 24.3 & 25.4 & 20.8 & 25.2 & 19.8 & 19.0 & 19.6 & 20.6 & \\
\hline Average real interest rate (nominal rate minus change in GDP deflator, ir & -7.7 & -10.1 & 3.2 & -0.6 & 0.7 & -0.3 & -0.6 & -0.6 & -1.1 & \\
\hline Exchange rate (LC per US dollar) & 2.4 & 2.9 & 2.9 & 3.3 & 3.3 & 3.2 & 3.2 & 3.2 & 3.1 & \\
\hline Nominal depreciation of local currency (LC per dollar) & -6.1 & 19.7 & -0.3 & 13.4 & 0.0 & -1.2 & -1.3 & -1.5 & -1.4 & \\
\hline Exchange rate (US dollar per LC) & 0.4 & 0.3 & 0.3 & 0.3 & 0.3 & 0.3 & 0.3 & 0.3 & 0.3 & \\
\hline Nominal appreciation (increase in US dollar value of local currency, in pe & 6.5 & -16.5 & 0.3 & $\ldots$ & $\ldots$ & $\ldots$ & $\ldots$ & $\ldots$ & $\ldots$ & \\
\hline Inflation rate (GDP deflator, in percent) & 13.5 & 15.2 & 2.8 & 6.2 & 4.8 & 5.4 & 5.6 & 5.7 & 6.3 & \\
\hline Growth of real primary spending (deflated by GDP deflator, in percent) & 12.0 & 12.4 & -2.7 & -2.3 & -4.6 & 1.1 & 1.7 & -0.5 & 1.0 & \\
\hline Primary deficit & 2.4 & 4.1 & 6.2 & 5.3 & 2.7 & 1.3 & 0.9 & 0.2 & -0.1 & \\
\hline
\end{tabular}

1/ Coverage: General government gross debt, excluding guarantees.

2/ Derived as $[(r-\pi(1+g)-g+\alpha \varepsilon(1+r)] /(1+g+\pi+g \pi))$ times previous period debt ratio, with $r=$ interest rate; $\pi=$ growth rate of GDP deflator; $g=$ real GDP growth rate; $\alpha=$ share of for denominated debt; and $\varepsilon=$ nominal exchange rate depreciation (measured by increase in local currency value of U.S. dollar).

3 / The real interest rate contribution is derived from the denominator in footnote $2 /$ as $r-\pi(1+g)$ and the real growth contribution as -g.

$4 /$ The exchange rate contribution is derived from the numerator in footnote $2 /$ as $\alpha \varepsilon(1+r)$.

$5 /$ For projections, this line includes exchange rate changes.

$6 /$ Defined as public sector deficit, plus amortization of medium and long-term public sector debt, plus short-term debt at end of previous period.

7/ The key variables include real GDP growth; real interest rate; and primary balance in percent of GDP.

$8 /$ Derived as nominal interest expenditure divided by previous period debt stock.

$9 /$ Assumes that key variables (real GDP growth, real interest rate, and other identified debt-creating flows) remain at the level of the last projection year. 
Table 11. Romania: External Debt Sustainability Framework, 2005-2015 (In percent of GDP, unless otherwise indicated)

\begin{tabular}{|c|c|c|c|c|c|c|c|c|c|c|c|c|}
\hline & \multicolumn{5}{|c|}{ Actual } & \multicolumn{7}{|c|}{ Projections } \\
\hline & 2005 & 2006 & 2007 & 2008 & 2009 & 2010 & 2011 & 2012 & 2013 & 2014 & 2015 & \\
\hline Baseline: External debt & 38.8 & 42.1 & 47.0 & 51.4 & 69.2 & 78.7 & 81.6 & 74.4 & 66.3 & 58.7 & 51.1 & $\begin{array}{c}\text { current account } 6 / \\
-7.2\end{array}$ \\
\hline Change in external debt & 3.6 & 3.3 & 4.9 & 4.4 & 17.8 & 9.5 & 2.8 & -7.2 & -8.1 & -7.6 & -7.6 & \\
\hline Identified external debt-creating flows $(4+8+9)$ & -7.2 & -5.7 & -4.3 & -2.3 & 14.5 & 3.8 & -0.5 & -1.9 & -2.4 & -2.0 & 0.3 & \\
\hline Current account deficit, excluding interest payments & 7.4 & 9.2 & 12.2 & 10.1 & 2.4 & 2.9 & 3.0 & 3.6 & 3.5 & 3.6 & 3.8 & \\
\hline Deficit in balance of goods and services & 10.2 & 12.0 & 14.0 & 13.2 & 6.5 & 6.4 & 7.2 & 7.1 & 6.7 & 6.2 & 5.7 & \\
\hline Exports & 33.1 & 32.1 & 29.2 & 30.4 & 31.6 & 36.3 & 37.4 & 36.9 & 36.5 & 36.2 & 35.5 & \\
\hline Imports & 43.3 & 44.2 & 43.2 & 43.6 & 38.1 & 42.7 & 44.6 & 44.0 & 43.2 & 42.4 & 41.1 & \\
\hline Net non-debt creating capital inflows (negative) & -7.5 & -8.6 & -5.8 & -6.1 & -3.5 & -3.4 & -5.4 & -5.1 & -5.6 & -5.3 & -3.2 & \\
\hline Automatic debt dynamics $1 /$ & -7.1 & -6.2 & -10.7 & -6.3 & 15.5 & 4.3 & 1.9 & -0.4 & -0.3 & -0.3 & -0.3 & \\
\hline Contribution from nominal interest rate & 1.2 & 1.2 & 1.1 & 1.4 & 1.9 & 3.0 & 3.1 & 2.8 & 2.5 & 2.2 & 1.9 & \\
\hline Contribution from real GDP growth & -1.1 & -2.5 & -1.9 & -2.9 & 4.6 & 1.4 & -1.2 & -3.3 & -2.8 & -2.5 & -2.2 & \\
\hline Contribution from price and exchange rate changes $2 /$ & -7.2 & -5.0 & -9.9 & -4.9 & 9.0 & & & & & & & \\
\hline Residual, incl. change in gross foreign assets (2-3) $3 /$ & 10.8 & 9.0 & 9.2 & 6.8 & 3.3 & 5.6 & 3.3 & -5.3 & -5.7 & -5.6 & -7.9 & \\
\hline External debt-to-exports ratio (in percent) & 117.3 & 131.0 & 160.7 & 169.0 & 219.0 & 216.9 & 218.1 & 201.7 & 181.7 & 162.2 & 143.9 & \\
\hline Gross external financing need (in billions of Euros) $4 /$ & 14.3 & 21.7 & 35.9 & 46.2 & 34.9 & 31.9 & 32.3 & 33.8 & 35.2 & 37.2 & 39.4 & \\
\hline in percent of GDP & 17.9 & 22.2 & 28.8 & 33.1 & 30.1 & 27.9 & 27.3 & 25.7 & 24.0 & 22.7 & 21.4 & \\
\hline Scenario with key variables at their historical averages 5 / & & & & & & 78.7 & 74.8 & 67.2 & 59.9 & 53.2 & 45.4 & -10.2 \\
\hline \multicolumn{13}{|l|}{ Key Macroeconomic Assumptions Underlying Baseline } \\
\hline Real GDP growth (in percent) & 4.2 & 7.9 & 6.3 & 7.3 & -7.1 & -1.9 & 1.5 & 4.4 & 4.2 & 4.2 & 4.2 & \\
\hline GDP deflator in Euros (change in percent) & 25.6 & 14.7 & 30.8 & 11.6 & -14.9 & 0.6 & 1.6 & 6.7 & 7.0 & 7.2 & 7.9 & \\
\hline Nominal external interest rate (in percent) & 4.5 & 3.8 & 3.7 & 3.6 & 2.9 & 4.2 & 4.1 & 3.8 & 3.7 & 3.7 & 3.7 & \\
\hline Growth of exports (Euro terms, in percent) & 20.7 & 19.3 & 15.9 & 16.6 & -13.7 & 13.3 & 6.3 & 9.9 & 10.3 & 10.8 & 10.4 & \\
\hline Growth of imports (Euro terms, in percent) & 26.1 & 25.2 & 24.7 & 13.2 & -27.4 & 10.4 & 7.9 & 9.9 & 9.6 & 9.5 & 9.3 & \\
\hline Current account balance, excluding interest payments & -7.4 & -9.2 & -12.2 & -10.1 & -2.4 & -2.9 & -3.0 & -3.6 & -3.5 & -3.6 & -3.8 & \\
\hline Net non-debt creating capital inflows & 7.5 & 8.6 & 5.8 & 6.1 & 3.5 & 3.4 & 5.4 & 5.1 & 5.6 & 5.3 & 3.2 & \\
\hline
\end{tabular}

1/ Derived as $[r-g-r(1+g)+$ ea( $1+r)](1+g+r+g r)$ times previous period debt stock, with $r=$ nominal effective interest rate on external debt; $r=$ change in domestic GDP deflator in Euro terms, $g=$ real GDP growth rate $=$ nominal appreci

$2 /$ The contribution from price and exchange rate changes is defined as $[-\rho(1+g)+\varepsilon \alpha(1+r)] /(1+g+\rho+g \rho)$ times previous period debt stock. $\rho$ increases with an appreciating domestic currency $(\varepsilon>0)$ and rising inflation (based on GDP deflator). $3 /$ For projection, line includes the impact of price and exchange rate changes.

4/ Defined as current account deficit, plus amortization on medium- and long-term debt, plus short-term debt at end of previous period.

ding

interest rate, dollar deflator growth, and non-debt inflows in percent of GDP) remain at their levels

of the last projection year. 


\section{APPENDIX I. ROMANIA: LETTER OF INTENT (LOI)}

Mr. Dominique Strauss-Kahn

Bucharest, December 22, 2010

Managing Director

International Monetary Fund

Washington, DC, 20431

U.S.A.

Dear Mr. Strauss-Kahn:

1. The anti-crisis program supported by the International Monetary Fund (IMF), the European Union (EU), and the World Bank (WB) has continued to play a crucial role in stabilizing the Romanian economy, reversing imbalances, rebuilding confidence of international financial markets, and setting the stage for future sustainable economic growth. Economic activity is now stabilizing and we expect growth to resume in the coming months, leading to an increase of around 1 1 $\frac{2}{2}$ percent in 2011 (compared to around -2 percent in 2010). Inflation has jumped sharply in recent months due to the effects of the July VAT increase and food price pressures. We expect inflation to peak at slightly above 8 percent at end 2010 before beginning to return to within the National Bank of Romania's target band in the course of 2011. We continue to project a current account deficit of about 5-6 percent of GDP for 2010 .

2. Our performance on the quantitative targets and the structural reform agenda has been strong (Tables 1 and 2).

- Quantitative performance criteria and indicative targets. All end-September 2010 quantitative performance criteria were observed, with the exception of that on general government arrears $(\Phi 8)$. However, we have taken action to assure that central government arrears are near zero and will remain so for the remainder of the program. The indicative target on the operating balance of loss-making state-owned enterprises was also missed. Inflation remained within the inner band of the inflation consultation mechanism throughout the period.

- Structural benchmarks. All structural benchmarks to end-December will be met, albeit with delays in some cases. We have reformed the Deposit Guarantee Fund's (DGF's) funding regime and have reviewed its governance structure by endSeptember, as programmed. The Unified Wage legislation will be approved by parliament in December (prior action), with only a small delay from the end-October target. There has been a delay in the parliamentary ratification of some of the June austerity measures and we now expect that this will take place in the context of the approval of the 2011 budget. While the earlier structural benchmark on approval of the pension reform law was met, there was a delay in enactment which we now expect in December ( $\$ 16$; prior action). We are making significant progress on other structural benchmarks under the program. 
3. In view of this performance - and of the supplementary and corrective actions outlined in this Letter - we request completion of the sixth review under the Stand-By Arrangement. We request a waiver of applicability for the targets on the general government balance, on the ceiling on government guarantees, and for the inflation consultation band. We also request a waiver of non-observance for the end-December performance criterion on general government arrears as that target is unlikely to have been met.

4. We believe that the policies set forth in the letters of April 24, 2009, September 8, 2009, February 5, 2010, June 16, 2010, June 29, 2010, September 9, 2010 and in this Letter are adequate to achieve the objectives of our economic program, but the government stands ready to take additional measures as appropriate to ensure achievement of its objectives. As is standard under all IMF arrangements, we will consult with the IMF before modifying measures contained in this Letter or adopting new measures that would deviate from the goals of the program, and will provide the IMF and the European Commission (EC) with the necessary information for program monitoring.

\section{Fiscal sector}

5. We are on track to meeting this year's fiscal targets, following the difficult fiscal adjustment measures applied in July. The overall deficit target for the end-September has been met with a significant margin due to strict expenditure control and better-thananticipated tax revenues. We also expect to meet the full year deficit target of 6.8 percent of GDP for 2010. The recent payment of health sector arrears and overdue bills produced a sharp drop in domestic payments arrears, but the end-September ceiling has been breached again given limited progress in the repayment of local government arrears. We will take action to maintain central government and social security arrears near zero for the remainder

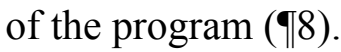

6. For 2011, we remain fully committed to reducing the deficit to 4.4 percent of GDP. On the revenue side, we intend to leave the main components of the tax system unchanged. On the spending side, we are committed to keeping the wage bill within the agreed limit of RON 39 billion, excluding contributions from the military (RON 1.6 billion under the new pension law), while calibrating wages, bonus payments, and public employment policies to ensure some recovery of real public sector wages. To secure the 2011 deficit target and compensate for the elimination of the minimum tax, we will take the following measures: (i) undertake further health sector reforms ( $\$ 17)$ to improve revenues and control expenditures; (ii) reduce the total subsidies for livestock welfare for 2011, after confirming the introduction of funding for these programs in the European National Program for Rural Development and further streamline state aid; (iii) continue public employment reductions by inter alia maintaining the policy of replacing only 1 of 7 departing workers; and (iv) broaden the base of health contributions to cover pensioners earning between RON 740 and RON 1000. We are continuing the comprehensive reform of the education system, which should improve the quality of instruction while generating additional savings as a result of rationalization of the school network and of the teacher workload. Within the budget envelope, we will allocate additional resources to investment in the first half of the year so as to improve absorption of 
EU funds. If absorption improves sufficiently, we will work on solutions to create greater fiscal space for investment from mid-2011. The European Union will provide expert assistance for utilizing the resources available from the EU, European Investment Bank, and the World Bank, including through innovative financing solutions. We stand ready to take compensatory actions if any judicial impediments arise to the execution of this fiscal strategy. Parliamentary approval of the agreed 2011 budget (including ratification of the 24 percent VAT rate) will be a prior action for the review. The remaining policies in the fiscal area remain as outlined in our letter of intent of September 9, 2010 ( $\mid 6)$.

7. For 2012, we aim to bring the deficit down to the 3 percent of GDP Maastricht target (in accrual terms). This will require continued expenditure restraint, including on wages and bonuses, and may require additional measures. We will strictly limit further ad hoc changes to the tax system to ensure predictability and stability. Once we are firmly on track to meeting our deficit target, we will undertake - with technical assistance from the IMF and in consultation with the EC and World Bank - a comprehensive review of the tax system with a view to its revenue-neutral optimization and simplification. Should the economic recovery create sufficient fiscal space, we will consider a gradual reduction in labor taxation, the high incidence of which weighs heavily on competitiveness, employment creation and labor market practices. The Medium-Term Fiscal Strategy for 2011-13 is an important step in implementing the Fiscal Responsibility legislation and in solidifying our commitment to the Maastricht targets. We also intend to begin discussions in the coming months on a new arrangement, which will help anchor our fiscal performance in 2011 and 2012. We will strengthen the recently established Fiscal Council by providing it with adequate funding so as to ensure that its secretariat is fully staffed with appropriately skilled people.

8. We continue our efforts in clearing outstanding payment arrears. At the central level, we paid off RON 1.9 billion in health arrears and overdue bills in September. We will allocate necessary funds in 2010-11 to prevent accumulation of further arrears and will assure that central government and social security sector arrears will remain near zero at endNovember 2010 (prior action). In line with a new EU directive, we will reduce over time the period for paying bills after submission to no more than 30 days. New legislation on local government finance will also allow for greater control of local government arrears beginning in January 2011. To improve commitment control, the recent IMF technical assistance mission helped us with efforts to integrate the accounting reporting system with the Treasury payment system. However, the reforms will take longer than anticipated and we will focus our initial efforts on completing the tender for consultants to implement the project and having a full project plan should be in place by March 2011 (modified structural benchmark reset for March 15, 2011). EU and World Bank experts will review the local government arrears issue with a view toward improving financial management in the local administrations. We will continue using budget appropriations as commitment ceilings and will enforce sanctions against institutions and individuals who breach the ceilings.

9. Our financing strategy will focus on extending the maturity of our domestic debt and consolidating the financial buffers. We will, thus, aim to transition from use of short-term 
cash management facilities to increased issuance of longer-term instruments under marketdetermined conditions, with a view to building a yield curve. We also plan to launch a "euro medium term notes" program in late 2010 or early 2011 that will maintain our presence in the external markets under more flexible issuance procedures and will help us balance the financing between the domestic and external markets. We are firmly committed to stabilizing our financial buffers over the coming months and to gradually increasing them to around 4 months of financing needs. To enhance our capabilities, in 2011 we will conduct a formal review of our debt management strategy with the assistance of IMF, EC, and World Bank experts.

\section{Fiscal and structural reforms}

10. We continue efforts to improve our tax collection and administration and to fight tax evasion. Work is progressing on a draft ordinance on high net wealth individuals to be approved by end-December (structural benchmark, reset from end-November) and an IMF expert will assist in its subsequent implementation. The definition of income will be broadened and the right to audit unreported income will be strengthened. As agreed with the IMF and the EC, we will request a shift in the VAT mandatory threshold from the EU Council of Ministers to EUR 50,000, while studying options for simplified taxation for smaller taxpayers under the threshold. Starting next year, we plan to implement new criteria to allocate taxpayers into small, medium, and large segments. The requirement of electronic filing for medium and large taxpayers has come into effect in November. We will continue our efforts to introduce information technology (IT) systems and consolidate the IT department in ANAF to improve tax administration. We will also provide customs and tax administration with the necessary technical equipment to fight tax evasion. We will continue our efforts to implement measures described in our previous letters.

11. The accelerated absorption of EU funds remains a focal objective of the government. Over the coming year, we will focus on strengthening the administrative capacity of units managing the funds; modernizing and consolidating the legislative and regulatory framework for public investment and other fields relevant for EU fund absorption; and prioritizing investment to assure sufficient financing for key projects as per recommendations in the recent functional reviews. Specifically, we are committed to: (i) giving priority to investment projects co-financed with EU funds when initiating new investments; (ii) prioritizing the existing portfolio of capital projects to focus on projects where funding can be fully secured, with low priority projects discontinued; (iii) strengthening the project appraisal process by requiring private sector review of the bankability of projects; (iv) encouraging private sector participation in projects via outsourcing or public-private partnership arrangements; and (v) ensuring full staffing of program management bodies and the adequate remuneration of the specialized staff, financed with support from technical assistance funds. The government will move the EU project management unit from the Ministry of Public Finance to the Prime Minister's office and strengthen its authority and staffing with full authority to take necessary actions across ministries to speed up EU funds absorption for investment projects to ensure 
economic growth. We will create facilities for reallocating the capital budget during the year to those ministries with the best absorption performance.

12. We are undertaking a social benefits reform to improve the efficiency of protection of the poorest and most vulnerable, while providing support for the fiscal adjustment strategy. Efficiency will be increased by allowing for more focused income and means tested eligibility criteria. The reform, which has already been submitted to parliament, will consolidate the guaranteed minimum income scheme, heating benefits and family allowance into one new means-tested scheme. Disability allowances will also be subject to an incometest. We will also streamline the current maternity policy to bring it more in line with the EU average. The draft is currently being discussed in the government. To reduce the significant rate of benefits fraud detected in recent inspections and increase spending efficiency, we have also doubled the personnel working on social benefit inspection.

13. The government continues efforts to improve the performance of public enterprises. The 10 largest loss-making public enterprises failed to meet the indicative target for operating losses in the third quarter. Moreover, arrears have continued to increase, violating EC conditionality on a quarterly reduction of arrears. Measures have been taken to improve the revenue side of these companies (via higher tariffs) as well as cost reductions via personnel cuts and restructuring, but progress continues to be slow. The government will continue the process of winding-up or privatizing state owned enterprises (including Termoelectrica and the cargo rail company) with the goal of securing an optimum price. The privatization agency AVAS continues work on preparing the sale of small firms under its majority ownership and the minority stakes it holds in at least 150 additional firms, but completion of most sales will be expected in 2011.

14. The government will continue to reform the transportation sector to reduce losses and clear arrears of the major SOEs in the railway and road transport sectors. This will be done through widening the revenue base, strengthening controls, reforming legislation to increase transparency of the procurement and contracting frameworks, and increasing reliance on value-for-money analysis of our investment projects. We also aim to gradually increase the system's use of railway transportation, away from roads, in order to reduce road maintenance costs. To boost absorption of EU funds, we will give priority to investment projects for crosscountry road and rail connections from Nadlac to Constanta (European Corridor IV), finalize the EU project portfolio for 2014-20, and contract independent experts to monitor project execution. Finally, we will restructure the Ministry of Transport and Infrastructure to strengthen administrative capacity through independent human resource evaluation and introduction of a performance-based remuneration system.

15. Preparation of framework and implementing legislation for the unified wage law is nearing completion. It is expected to be approved by parliament in December 2010 (prior action). The parameters will ensure that: (i) the public wage bill remains within the agreed envelope for 2011; (ii) all remaining bonuses are set as ceilings rather than mandatory levels, both at an individual and aggregate level, allowing for flexibility according to performance and budgetary conditions; (iii) the productivity bonus system (stimulente) will be eliminated 
by incorporating it into the basic wage and annulling the legislative provisions that create its financing fund, while allowing some flexibility for rewarding strong tax collections within the overall bonus ceiling. The government remains committed to further reductions in public employment in the remainder of 2010 and in 2011.

16. Enactment of the pension reform was delayed because the president sent it back to parliament to reconsider of the pension age of women. The parliament has reapproved the legislation early December and it will be signed by the president and enacted by midDecember (prior action). As noted in our September letter, we have suspended early retirements until the new law enters into force, and the new pension indexation provisions will enter into effect in 2012, after the 2011 pension freeze expires.

17. The government will continue restructuring the health sector to ensure the functioning of health care system within budgetary allocations going forward. While we continue to implement measures to reduce healthcare costs (see LOIs of June 16, June 29, and September 9,2010 ), these have proven insufficient to balance the much reduced budget for the health system without accumulating arrears. To achieve an appropriate balance between the need to preserve adequate healthcare services and to control costs, we will undertake the following measures in 2010 that will be continued in 2011:

- Ensure that the revised 2010 and the 2011 budget for the health system are consistent with the projected spending after restructuring measures.

- To increase the revenues of the system, we will: (i) approve urgent legislation to establish a beneficiary copayment for all healthcare services (excluding emergency), with exemptions based solely on means-testing to protect the most vulnerable; and (ii) clarify the legislative framework for the clawback tax on drug suppliers.

- To further reduce spending, we will: (i) restructure the hospital system; (ii) limit the number of contracted hospital in-patients by 10 percent relative to the 2010 levels, through annual contracts with the hospitals; (iii) eliminate mandatory contracting with all hospitals, allowing competitive contracting with selected hospitals while ensuring transparency and oversight; (iv) reduce the price markup paid by the government for drugs in the national programs (list C2) at both retail and wholesale levels to 1.5 and 4 percent, respectively; (v) in the primary healthcare system, reduce the share of per-capita reimbursement of doctors from 70 to 50 percent, in favor of per-service reimbursement; and (vi) reform, with assistance from the World Bank, the package of benefits insured by the government to exclude coverage of costly nonessential health services.

- To improve controls over the financial performance of the sector, we will cap the nominal amount of quarterly services contracted with hospitals, primary care doctors and pharmacies to budgeted amounts; and develop a transparent and integrated IT system in the Ministry of Health and Health House to monitor and increase efficiency of health spending and to use the system as a basis for health policymaking. 
18. We are continuing work on labor market reforms to increase flexibility, increase representativity in the negotiations between social partners, and encourage greater labor force participation, particularly for young people. We have submitted to parliament a revised law on day laborers to parliament, and a draft enhanced apprenticeship law is ready for submission. Before end-December (after consultation social partners and with the IMF, the World Bank and the European Commission), we will send a revised social dialog code and an improved labor code to parliament. We are also making efforts to improve the provision of training programs to low-skilled workers. After freezing the minimum wage since 2008, we will raise it to broadly compensate for recent inflation, while delinking the unemployment benefits from the minimum wage.

\section{Financial sector}

19. The protracted recession and uncertainty caused by recent government ordinance on credit contracts is weighing on asset quality and on the profitability of the banking sector. Loans classified as doubtful and loss rose to 20.2 percent, while those calculated on the 90 day loss classification reached 11.7 percent at end-September, and they are expected to continue to rise into next year. Capitalization ratios stayed high due to timely injections of capital by banks, but pressures remain due to losses from increased provisioning in a number of banks. The average capitalization ratio for the banking sector was 14.6 percent at endSeptember, and all institutions remained above 11 percent. Nearly all parents of the nine largest foreign banks have complied with their commitment to maintain exposures under the European Bank Coordination Initiative (EBCI) and in aggregate ended October at 98 percent.

20. We are committed to continuing the consolidation of the safety net to deal with financial distress. The parliament has ratified the amendments to the banking law, which enable the special administrator to promptly implement a broad range of restructuring measures, and amendments to the winding up law are expected to be ratified shortly. We have taken steps to strengthen the funding and governance of the Deposit Guarantee Fund (DGF) and will amend the deposit insurance legislation accordingly by end-December (structural benchmark). We will also amend by ordinance the DGF law by mid-March, 2011, to allow for the use of resources administered by the DGF (including through guarantees) to facilitate restructuring measures authorized by the National Bank of Romania (NBR) regarding the transfer of deposits, including purchase and assumption transactions, if such use would be less costly than the direct payment of deposit guarantees (structural benchmark). The current provisioning framework is sound and the NBR does not consider that any new prudential regulation in this area is necessary at present. The NBR will continue to consult with the IMF and EC staff before introducing or amending other aspects of the regulatory framework and we will refrain from promoting legislative initiatives (such as the current draft of the personal insolvency law) that would undermine credit discipline.

21. As a prior action, we will work with parliament to ensure that the emergency ordinance 50 of 2010 improves transparency and protects consumer rights, while safeguarding the stability of the financial system. At the same time, we will ensure that the National Bank is the only agency authorized to regulate banks' lending activity. 
22. We remain committed to reversing recent legislative initiatives that inadvertently infringed on the independence of the central bank and of non-bank financial regulators. An ordinance was issued removing monetary financing provisions of the wage cuts imposed on the NBR, and we will reverse provisions violating the autonomy of wage-setting by endDecember.

\section{Monetary and exchange rate policy}

23. So far, the effects of the recent increase in VAT on inflation have been somewhat less than expected. However, food price pressures from higher world prices and the effects of recent flooding on domestic agricultural production have pushed the headline CPI somewhat above previous expectations. We now expect inflation to peak in the coming months at slightly above 8 percent before receding in 2011. Barring significant second-round increases, the price-level effects should peter out after mid-2011, allowing the attainment of the end2011 target of 3 percent \pm 1 percentage point. There are risks, however, if second round effects materialize or if significant adjustments in administered prices take place. While the one-off nature of the VAT-induced price increase does not warrant a monetary policy response, increased vigilance is required to keep inflation expectations in check and stave off possible second-round inflationary effects. The NBR board has paused its easing cycle until the effects of the VAT increase become clearer and headline inflation begins to ease. Looking forward, monetary policy will be geared towards reaching the projected disinflation path net of the first-round tax effect.

\section{Program modifications and monitoring}

24. The program will continue to be monitored through regular reviews, prior actions, quantitative performance criteria and indicative targets, and structural benchmarks. The quantitative targets for end-December and continuous PCs have been set at the fifth review and are subject to clarifications as set out in the attached updated Technical Memorandum of Understanding. An end-January 2011 NFA performance criterion and indicative targets for end-March 2011 are proposed as set out in Table 1 and the structural benchmarks are set out in Table 2. The understandings between the Romanian authorities and IMF staff regarding the quantitative performance criteria and the structural measures described in this letter are further specified in the attached Technical Memorandum of Understanding.

$/ \mathrm{s} /$

Gheorghe Ialomiţianu

Minister of Public Finance /s/

Mugur Isarescu

Governor of the National Bank of Romania 
Table 1. Romania: Quantitative Program Targets

\begin{tabular}{|c|c|c|c|c|c|c|c|c|c|c|c|c|}
\hline & \multirow{3}{*}{$\begin{array}{c}2008 \\
\text { Dec } \\
\text { Actual } \\
\end{array}$} & \multicolumn{4}{|c|}{2009} & \multicolumn{5}{|c|}{2010} & \multicolumn{2}{|c|}{2011} \\
\hline & & \multirow{2}{*}{$\begin{array}{l}\text { March } \\
\text { Actual }\end{array}$} & \multirow{2}{*}{$\begin{array}{l}\text { June } \\
\text { Actual }\end{array}$} & \multirow{2}{*}{$\begin{array}{r}\text { Sept } \\
\text { Actual } \\
\end{array}$} & \multirow{2}{*}{$\begin{array}{l}\text { Dec } \\
\text { Actual } \\
\end{array}$} & \multirow{2}{*}{$\begin{array}{l}\text { March } \\
\text { Actual }\end{array}$} & \multirow{2}{*}{$\begin{array}{l}\text { June } \\
\text { Actual }\end{array}$} & \multicolumn{2}{|c|}{ Sept } & \multirow{2}{*}{$\begin{array}{l}\text { Dec } \\
\text { Prog. }\end{array}$} & \multirow{2}{*}{$\begin{array}{l}\text { January } \\
\text { Perf. crit. In }\end{array}$} & \multirow{2}{*}{ March } \\
\hline & & & & & & & & Prog. & Actual & & & \\
\hline \multicolumn{13}{|l|}{ I. Quantitative Performance Criteria } \\
\hline 1. Change in net foreign assets (mln euros) $1 / 2 /$ & 25,532 & $-3,500$ & $-5,119$ & $-4,566$ & $-4,874$ & 779 & -509 & $-2,000$ & -318 & $-2,000$ & 0 & 350 \\
\hline 2. Floor on general government overall balance (mln lei) $3 / 4 / 5 /$ & $-24,655$ & $-8,300$ & $-14,456$ & $-25,563$ & $-36,101$ & $-8,422$ & $-18,015$ & 27,505 & 23,732 & $-34,650$ & & $-6,300$ \\
\hline 3. Stock in general government arrears (bn lei) & 1.06 & 1.41 & 1.55 & 1.4 & 1.50 & 1.76 & 1.8 & 0.81 & 1.57 & 0.48 & & 0 \\
\hline 4. Ceiling on general government guarantees issued since start of program (face value, bn & $\ldots$ & $\ldots$ & 0.02 & 0.8 & 2.2 & 4.6 & 5.5 & 12.0 & 6.5 & 12.0 & & 12.0 \\
\hline \multicolumn{13}{|l|}{ II. Continuous Performance Criterion } \\
\hline 5. Nonaccumulation of external debt arrears & 0 & 0 & 0 & 0 & 0 & 0 & 0 & 0 & 0 & 0 & & 0 \\
\hline \multicolumn{13}{|l|}{ III. Inflation Consultation } \\
\hline Outer band (upper limit) & $\ldots$ & $\ldots$ & 8.4 & 7.7 & 6.5 & 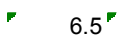 & 6.0 & 10.0 & $\ldots$ & 10.0 & & 9.0 \\
\hline Inner band (upper limit) & $\ldots$ & $\ldots$ & 7.4 & 6.7 & 5.5 & 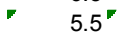 & 5.0 & 9.0 & $\ldots$ & 9.0 & & 8.0 \\
\hline Actual/Center point & 6.3 & 6.7 & 5.9 & 4.8 & 4.7 & 4.2 & 4.4 & 8.0 & 7.8 & 8.0 & & 7.0 \\
\hline Inner band (lower limit) & $\ldots$ & $\ldots$ & 5.4 & 4.7 & 3.5 & 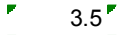 & 3.0 & 7.0 & $\ldots$ & 7.0 & & 6.0 \\
\hline Outer band (lower limit) & $\ldots$ & $\ldots$ & 4.4 & 3.7 & 2.5 & $2.5^{\prime \prime}$ & 2.0 & 6.0 & $\ldots$ & 6.0 & & 5.0 \\
\hline \multicolumn{13}{|l|}{ IV. Indicative Target } \\
\hline $\begin{array}{l}\text { 7. General government current primary spending (excl. EU funds and social assistance, mlt } \\
\text { 8. Operating balance (earnings before interest and tax) net of subsidies of } 10 \text { SOEs, } \\
\text { defined in TMU (mln. lei) } 3 /\end{array}$ & 92,327 & 22,149 & 43,238 & 63,878 & 85,637 & $\begin{array}{r}32,749 \\
-1,081\end{array}$ & $\begin{array}{r}66,124 \\
-2,333\end{array}$ & $\begin{array}{r}100,000 \\
-3,000\end{array}$ & $\begin{array}{r}98,721 \\
-3,801\end{array}$ & $\begin{array}{r}131,500 \\
-4,000\end{array}$ & & $\begin{array}{r}32,200 \\
-750\end{array}$ \\
\hline \multicolumn{13}{|l|}{ Memorandum Item: } \\
\hline Revenue of general government, net of EU funds ( $\mathrm{mln}$. lei) 3/ & $\ldots$ & $\ldots$ & $\ldots$ & $\ldots$ & 151,508 & 36,355 & 74,669 & 114,700 & 116,091 & 157,950 & & 40,100 \\
\hline
\end{tabular}

1/ The December 2008 figure is a stock.

2/ Performance criterion for January 2011 and indicative target for March 2011 are relative to December 2010 target.

3/ Cumulative figure during calendar year (e.g. March 2011 figure is cumulative from January 1, 2011).
4/ In accordance with TMU, the end-September program target was adjusted from the original target of $-28,200$ by one-half of the revenue over-performance.

5/ The target for March 2011 can be adjusted with higher or lower capital spending as defined in TMU. 
Table 2. Romania: Performance for Sixth Review and Proposed New Conditionality

Prior actions

1. Parliamentary approval of the agreed 2011 budget, including ratification of the 24 percent VAT rate

2. Ensuring central government and social security arrears at near zero at endNovember 2010

3. Approval of the unified public wage legislation

4. Enactment of the pension reform

5. Amending ordinance on credit contracts so that it improves transparency and protects consumer rights while safeguarding the stability of the financial system.

Quantitative performance criteria

1. Floor on net foreign assets

2. Floor on general government overall balance

3. Ceiling on general government guarantees

4. Ceiling on general government domestic arrears

5. Non-accumulation of external debt arrears

September, $2010 \quad$ Met

September, $2010 \quad$ Met

September, $2010 \quad$ Met

September, $2010 \quad$ Missed

September, $2010 \quad$ Met

September, $2010 \quad$ Met

1. Ceiling on general government current primary spending

2. An indicative target on the operating balance of ten largest loss-making SOEs

\section{Inflation consultation band}

Inner band

Outer band

\section{Structural benchmarks}

1. Approval of reforms to mitigate fiscal risks from local governments

2. Reform of the DGF's funding regime through increase in bank's contribution rates and elimination of stand-by credit lines, and review of DGF governance arrangement

3 Parliamentary ratification of the fiscal measures approved by the government

4 Passage of framework and implementing legislation for the unified wage law

5 Reform tax administration methodology for high net wealth individuals

6 Parliamentary ratification of amendments to the bank resolution framework

7. Parliamentary approval of agreed 2011 budget

8. Amend deposit insurance legislation to ensure that neither members of the board nor employees of credit institutions participate in the DGF Board

9. First phase to integrate the accounting reporting system with the Treasury payment system
September, $2010 \quad$ Missed

September, $2010 \quad$ Met

September, $2010 \quad$ Met

September 30, 2010 Met in June 2010

September 30, 2010 Met; the reform of the governance arrangement modified to endDecember 2010

September 30, 2010 Partially met, VAT ratification reset as prior

October 31, 2010 Not met, reset as prior action

November 30, 2010 Reset to December 31, 2010

December 1, $2010 \quad$ Partially met

December 15, 2010 Reset as prior action

December 31, 2010

March 31, 2011

Modified and reset for March 15, 2011

\section{Proposed structural benchmarks}

10. Amend legislation to allow the use of the deposit guarantee fund resources to March 15, 2011 facilitate bank restructuring, including purchase and assumption transactions 


\section{APPENDIX II. ROMANIA: TEChNICAL MEMORANDUM OF UNDERSTANDING (TMU)}

\section{December 22, 2010}

\section{This Technical Memorandum of Understanding (TMU) updates and replaces the} TMU dated September 9, 2010. It: (i) defines the variables subject to the quantitative targets specified in the Letter of Intent (LOI); (ii) describes the methods to be used in assessing the program performance and the information requirements to ensure adequate monitoring of the targets (Section I); and (iii) provides clarifications for some of the structural conditionality under the program (Section II). As is standard under all Fund arrangements, we will consult with the Fund before modifying measures contained in this letter, or adopting new measures that would deviate from the goals of the program, and provide the Fund with the necessary information for program monitoring.

2. For the purposes of the program, the exchange rates of the Romanian Leu (RON) to the euro is set at RON $3.9852=€ 1$, to the U.S. dollar at RON $2.8342=\$ 1$, to the Japanese yen at RON $3.1419=¥ 100$, and to the pound sterling at RON $4.1169=£ 1$, the rates as shown on the National Bank of Romania's (NBR's) website as of December 31, 2008. The exchange rates to other currencies, where applicable, will also be the ones shown on the NBR's website as of December 31, 2008.

3. For the purposes of the program, the general government includes the entities as defined in the 2010 budget. These are: the central government (state budget, treasury, selffinanced state entities included in the budget, etc.), local governments, social security funds (pension, health, and unemployment), road fund company, and administration of the property fund. This definition of general government also includes any new funds, or other special budgetary and extra budgetary programs that may be created during the program period to carry out operations of a fiscal nature as defined in the IMF's Manual on Government Finance Statistics 2001. The authorities will inform IMF staff of the creation of any such new funds or programs immediately.

\section{Quantitative Performance Criteria, Indicative Ceiling, and Continuous Performance Criteria}

\section{A. Floor on the Net Foreign Assets}

4. For program purposes, Net Foreign Assets (NFA) are defined as the NFA of the NBR minus Treasury liabilities to the International Monetary Fund.

5. NFA of the National Bank of Romania (NBR) are defined as the euro value of gross foreign assets of the NBR (including reserve requirements of the commercial banking system held at the NBR) minus gross foreign liabilities of the NBR; and will be measured on the basis of the NBR's operational rather than accounting definitions. Non-euro denominated foreign assets and liabilities will be converted into euro at the program exchange rates. 
6. Gross foreign assets of the NBR are defined to include the NBR's holdings of SDRs, the country's reserve position at the Fund, holdings of cash, securities and deposits abroad in convertible foreign currencies. Excluded from reserve assets are: (i) gold and other precious metals; (ii) assets in nonconvertible currencies; (iii) illiquid assets; (iv) any assets that are pledged, collateralized, or otherwise encumbered, unless there is also a gross foreign liability associated with it; (v) claims on residents; and (vi) claims in foreign exchange arising from derivatives in foreign currencies vis-à-vis domestic currency (such as futures, forwards, swaps, and options).

7. Gross foreign liabilities of the NBR are defined as all foreign exchange liabilities to residents and nonresidents, including commitments to sell foreign exchange arising from derivatives (such as futures, forwards, swaps, and options), and all credit outstanding from the Fund, but excluding (i) banks' foreign currency deposits against reserve requirements; and (ii) government foreign currency deposits at the NBR. This definition is meant to bring the concept of foreign liabilities closer to the balance of payment definition, on which the targets are based.

Floor on cumulative change in NFA from the beginning of the year (in mln. euros) 1/

\begin{tabular}{|c|c|c|c|c|c|c|c|}
\hline & \multirow{2}{*}{$\begin{array}{c}2009 \\
\text { December } \\
\text { (Stock) }\end{array}$} & \multicolumn{4}{|c|}{$20102 /$} & \multicolumn{2}{|c|}{$20112 /$} \\
\hline & & $\begin{array}{l}\text { March } \\
\text { Actual }\end{array}$ & $\begin{array}{c}\text { June } \\
\text { Actual }\end{array}$ & $\begin{array}{c}\text { Septembe } \\
\text { Actual }\end{array}$ & $\begin{array}{c}\text { December } \\
\text { PC }\end{array}$ & $\begin{array}{c}\text { January } \\
\text { PC }\end{array}$ & $\begin{array}{c}\text { March } \\
\text { Indicative }\end{array}$ \\
\hline $\begin{array}{l}\text { Cumulative change in } \\
\text { NFA }\end{array}$ & 20,658 & 779 & -509 & -318 & $-2,000$ & 0 & 350 \\
\hline $\begin{array}{l}\text { Memorandum Item: } \\
\text { Gross Foreign Assets }\end{array}$ & 28,418 & 3,145 & 1,838 & 3,724 & 3,000 & & 2,100 \\
\hline
\end{tabular}

8. NFA targets will be adjusted upward (downward) by the surplus (shortfall) in program disbursements relative to the baseline projection. Program disbursements are defined as external disbursements from official creditors (World Bank and the EC) that are sable for the financing of the overall central government budget. The NFA targets will also be adjusted upward by the increase in commercial bank reserve requirements held with the NBR relative to end-December, 2009 (€7,874 million), measured at program exchange rates. 
External Program Disbursements - Baseline Projections (in mln. euros)

\begin{tabular}{lllllc}
\hline & \multicolumn{3}{c}{2010} & 2011 \\
\cline { 2 - 5 } & March & June & September & December & March \\
\hline $\begin{array}{l}\text { Cumulative flows from end } \\
\text { of previous year }\end{array}$ & 1,000 & 2,200 & 2,500 & 4,100 & 1,500 \\
\hline
\end{tabular}

\section{B. Consultation Mechanism on the 12-month Rate of Inflation}

9. The quarterly consultation bands for the 12-month rate of inflation in consumer prices (as measured by the headline consumer price index (CPI) published by the Romanian Statistical Institute), are specified below. Should the observed year-onyear rate of CPI inflation fall outside the outer bands specified below, the authorities will complete a consultation with the Fund on their proposed policy response before requesting further purchases under the program. In addition, the NBR will conduct discussions with the Fund staff should the observed year-on-year rate of CPI inflation fall outside the inner bands specified for the end of each quarter in the table above.

\begin{tabular}{llllllc}
\hline & 2009 & \multicolumn{3}{c}{2010} & 2011 \\
\cline { 3 - 6 } & $\begin{array}{l}\text { December } \\
\text { (actual) }\end{array}$ & $\begin{array}{l}\text { March } \\
\text { (actual) }\end{array}$ & $\begin{array}{l}\text { June } \\
\text { (actual) }\end{array}$ & $\begin{array}{l}\text { September } \\
\text { (actual) }\end{array}$ & $\begin{array}{l}\text { December } \\
\text { (target) }\end{array}$ & $\begin{array}{c}\text { March } \\
\text { (indicative) }\end{array}$ \\
\hline Outer band (upper limit) & & & & & 10.0 & 9.0 \\
Inner band (upper limit) & & & & & 9.0 & 8.0 \\
Actual / Center point & 4.7 & 4.2 & 4.4 & 7.8 & 8.0 & 7.0 \\
Inner band (lower limit) & & & & & 7.0 & 6.0 \\
Outer band (lower limit) & & & & & 6.0 & 5.0 \\
\hline
\end{tabular}

\section{Performance Criterion on General Government Balance}

10. The budget deficit will be monitored quarterly through the cash balance of the general government. The authorities will consult with IMF staff on corrective measures in the event of shortfalls in government revenue and financing.

Cumulative floor on general government balance

(In millions of lei)

End-December 2009 (actual)

$-36,101$

End-March 2010 (actual)

$-8,422$

End-June 2010 (actual)

$-18,015$

End-September 2010 (actual)

$-23,325$

End-December 2010 (performance criterion)

$-34,650$

End-March 2011 (indicative)

$-6,300$ 
11. The budget deficit will be measured from above the line using the budget execution data. The Ministry of Public Finance (MoPF) will also provide monthly data to measure the deficit from below the line. The balance of the general government measured from below the line will include:

+ (i) net external financing, excluding valuation gains and losses;

+ (ii) change in net domestic credit from the financial system, excluding valuation gains and losses from deposits denominated in foreign currency and including adjustments for;

+ (a) received EU funds not yet spent (advance payments);

+ (b) claims of the government on EU funds;

+ (c) property fund obligations not yet paid;

+ (iii) change in the stock of issued government securities, net of valuation changes;

+ (iv) net changes in other financing.

12. If the difference between the general government deficit measured from above the line and from below the line is larger than lei 200 million each quarter during 2010, the MoPF will consult with IMF staff.

13. In the event that non-grant revenues exceed those projected under the program, the deficit target will be adjusted downward by one half of the surplus to allow for additional capital spending while reducing the deficit further. The following table shows the accumulated projected non-grant revenue for 2010, to which the actual non-grant revenue will be compared.

\begin{tabular}{lc}
$\begin{array}{l}\text { Cumulative projected revenue of general government, net of EU } \\
\text { funds }\end{array}$ & (In millions of lei) \\
\hline End-December 2009 (actual) & 151,508 \\
End-March 2010 (actual) & 36,355 \\
End-June 2010 (actual) & 74,669 \\
End-September 2010 (actual) & 115,966 \\
End-December 2010 (projection) & 157,950 \\
End-March 2011 (projection) & 40,100 \\
\hline
\end{tabular}

14. In the event that current spending in the previous quarter exceeds the indicative target (defined below), deficit target for the next quarter will be adjusted downward by a corresponding amount.

15. The indicative target for the general government balance for the first quarter of 2011 will be adjusted downward from $-6,300$ by the amount that capital spending (including EU funds-related spending) exceeds 5,740 million lei, up to a limit of -8,000 
million. Likewise, the target will be adjusted upward by the amount of that capital spending undershoots 5,740 million lei in the first quarter of 2011.

D. Performance Criterion Limiting the Issuance of Government Guarantees to the Non-Financial Private Sector and Public Enterprises

16. The issuance of general government guarantees to the non-financial private sector and public enterprises will be limited during the program period. This ceiling may be adjusted upward by up to RON 4.3 billion relative to the original ceiling of RON 7.7 billion for guarantees for financing the counterpart payments of investment projects financed by the EU or for guarantees on projects cofinanced by the EBRD, IBRD/IFC, EIB, AfDB, IADB, ADB, Council of Europe Development Bank, Black Sea Trade and Development Bank, Nordic Investment Bank, KfW, JICA and Export Import Bank of the U.S.

Ceiling on new general government guarantees issued from end2008 until:

(In billions of lei)

End-December 2009 (actual)

End-March 2010 (actual)

4.6

End-June 2010 (actual)

5.5

End-September 2010 (actual)

6.5

End-December 2010 (performance criterion)

12

End-March 2011 (indicative)

12

\section{E. Performance Criterion on Non-Accumulation of Domestic Arrears by the General Government}

\section{The performance criterion established on the stock in domestic payments} arrears of the general government contemplates no accumulation of new arrears and their elimination during the program period. The stock will be measured net of intergovernmental arrears, but both gross and net arrears will be reported by the government. In case of need, the government will take corrective measures to prevent the accumulation of new spending arrears. For the purpose of the program, arrears mean accounts payable past due date by 90 days (in line with ESA95 definitions for expenditures). Separate from the performance criterion defined above, we will make necessary payments to ensure that the stock of arrears in the central government and social funds (as defined in $q 3$ above) is under 250 million lei as of November 30, 2010.

\begin{tabular}{lc} 
Stock in general government arrears from the end of previous year & (In billions of lei) \\
\hline & \\
End-November 2009 (stock, actual) & 1.40 \\
End-March 2010 (actual) & 1.76 \\
End-June 2010 (actual) & 1.8 \\
\hline
\end{tabular}




$\begin{array}{lc}\text { End-September } 2010 \text { (actual) } & 1.5 \\ \text { End-December } 2010 \text { (performance criterion) } & 0.48 \\ \text { End-April 2011 (indicative target) } & 0.00\end{array}$

\section{F. Continuous Performance Criteria on Non-Accumulation of External Debt Payments Arrears by the General Government}

18. The general government will not accumulate external debt arrears during the program period. For the purposes of this performance criterion, an external debt payment arrear will be defined as a payment by the general government, which has not been made within seven days after falling due. The performance criterion will apply on a continuous basis.

\section{G. Indicative Target on General Government Current Primary Spending}

19. The indicative target on current primary expenditure of the general government is defined as spending on personnel, goods and services excluding EU funds (specified under external grant category), subsidies, transfers to public entities, pensions (social security budget in social assistance category and one-third of the state budget in the same category), state aid and other spending in other transfers category, Reserve Fund, and other expenditure as classified in the monthly reporting tables. The current spending target will be adjusted for the extra spending due to swap arrangement between local governments and public enterprises by an amount spent in the respective quarter. ${ }^{13}$

\begin{tabular}{lc}
\hline $\begin{array}{l}\text { Cumulative change in general government current primary } \\
\text { expenditures }\end{array}$ & $\begin{array}{c}\text { (In millions of } \\
\text { lei) }\end{array}$ \\
\hline & \\
End-December 2009 (actual) & 85,637 \\
End-March 2010 (actual) & 32,749 \\
End-June 2010 (actual) & 66,124 \\
End-September 2010 (actual) & 98,277 \\
End-December 2010 (indicative target) & 131,500 \\
End-March 2011 (indicative target) & 32,200 \\
\hline
\end{tabular}

\section{H. Monitoring of Public Enterprises}

20. As of 2009, the Ministry of Public Finance, the Ministry of Labor and Social Protection, and other pertinent institutions have implemented a monitoring system of public enterprises. During the program period, information will be provided to document that sanctions - decline in remuneration and dismissal of management according to

\footnotetext{
${ }^{13}$ The swap arrangement would involve mutually cancelling overdue tax obligations of public enterprises with arrears owed to those enterprises by the general government (local administration).
} 
Ordinances 37/2008 and 79/2008 — are imposed if the budgets and company targets for restructuring are not observed.

21. The quarterly indicative target for 2010 is set on the aggregate operating balance (earnings before interest and tax), net of subsidies, of the following public enterprises: (1) C.N. Cai Ferate CFR; (2) S.N. Transport CFR Calatori; (3) CN a Huilei; (4) SC Termoelectrica; (5) C.N. de Autostrazi si Drumuri Nationale; (6) S.C. Metrorex; (7) S.N. de Transport Feroviar CFR Marfa S.A.; (8) SC Electrocentrale Bucuresti; (9) Societatea Comerciala Electrificare CFR S.A.; and (10) S.C. Administratia Nationala a Imbunatatirilor Funciare. The data shall be reported with operating results by firm. The targets for December 2010 and March 2011 will be -4000 and -750 million lei, respectively.

\section{Reporting Requirements}

\section{Performance under the program will be monitored from data supplied to the} IMF by the NBR and the MoPF as outlined in Table 1. The authorities will transmit promptly to the IMF staff any data revisions as well as other information necessary to monitor the arrangement with the IMF.

Table 1. Romania: Data Provision to the IMF

\begin{tabular}{|c|c|}
\hline Item & Periodicity \\
\hline
\end{tabular}

To be provided by the Ministry of Finance

Preliminary monthly data on general government accounts

Quarterly final data on general government accounts

The budget deficit of the general government using ESA95 definition

Preliminary data on below-the-line financing for the general government

Final quarterly data on below-the-line financing for the general government

Total accounts payable and arrears of the general government

Stock of the central government external arrears Public debt and new guarantees issued by the general government

Preliminary monthly data on general government primary spending, net of EU disbursements

Final quarterly data on general government primary spending, net of EU disbursements

From 2010, the operating balance, profits, arrears, and personnel expenditures of 10 largest public enterprises by total expenditures

Data on EU project grants (reimbursements and
Monthly, on the $25^{\text {th }}$ day of the following month

Quarterly cash data, on the $35^{\text {th }}$ day past the test date Quarterly accrual data, on the $55^{\text {th }}$ day past test date Quarterly, with a lag of three months

Monthly, with a lag of no more than 35 days past the test date

Quarterly, no later than 45 days past the test date

Preliminary monthly, within the next month.

Quarterly, within 55 days

Daily, with a lag of not more than seven days

Monthly, within one month

Preliminary monthly data will be reported to the IMF staff within 25 days

Quarterly, within 35 days from the test date

Quarterly, within 55 days

Monthly, within three weeks of the end of each month 
advances), capital expenditures and subsidies covered by EU advances or eligible for EU reimbursement on EU supported projects specifically agreed with the EU

\section{To be provided by the National Bank of Romania}

NFA data, by components, in both program and actual exchange rates

Monetary survey data in the format agreed with IMF staff

The schedule of contractual external payments of the banking sector falling due in the next four quarters, interest and amortization (for medium and long-term loans)

The schedule of contractual external payments of the corporate sector falling due in the next four quarters interest and amortization (for medium and long-term loans)

The stock of short-term external debt of banks and corporate

Balance of payments in the IMF format currently used to report

Exposure (deposits, loans, subordinated loans) of (i) Weekly, each Monday succeeding the reporting week and with a 3 working day lag in the case of endquarter data

Monthly, within 30 days of the end of the month

Monthly, 45 days after the end of each month

Monthly, 45 days after the end of each month

Monthly, 45 days after the end of each month

Monthly, 45 days after the end of each month

Monthly, 20 days after the end of each month foreign parent banks to their subsidiaries in Romania; (ii) IFI and (iii) other creditors to banks in Romania (by national and foreign currency).

\section{Structural Conditionality: Specifications}

\section{A. Public Wage Legislation}

\section{Following the unified public wage law approved in October 2009, a new} framework law and implementing legislation for 2011 will be approved before the sixth review IMF Board meeting that will abide by the following principles:

a. It will ensure the respect of the quantitative targets for the public wage bill included in the unified public wage law and the proposed changes will be fully costed.

b. It will ensure that new salary grading structure is simplified and that pay will be linked based on job responsibility and qualification. The established new pay system will be benchmarked on private sector wages (through a salary survey) to ensure that public pay is broadly aligned with actual labor market conditions, within affordability constraints. 
c. The regulation would introduce a limit of 30 percent on non-wage personnel expenditures and caps on individual bonuses for non-military personnel. All remaining bonuses will be set as ceilings rather than mandatory levels, both at an individual and aggregate level. For the purpose of this law, "stimulus" payments will be treated as bonuses and the legislative provisions that created corresponding financing funds will be annulled.

\section{B. Financial Sector: Emergency Ordinance 50/2010}

24. The ordinance will be amended before being adopted by parliament to either remove the retroactive component, or alternatively to allow banks full flexibility to adjust contractual terms on loan contracts entered into prior to the ordinance coming into effect so as to safeguard financial sector stability. In addition, we will ensure that the National Bank is the only agency authorized to regulate banks' lending activity. 
This page intentionally left blank 


\title{
Sixth Review Under the Stand-By Arrangement, Request for Waiver of Nonobservance of Performance Criterion, and Request for Waiver of Applicability- Supplementary Information
}

\author{
Prepared by the European Department \\ (In Consultation with Other Departments)
}

Approved by Poul M. Thomsen and Aasim Husain

January 5, 2011

1. This supplement provides an update on economic and policy developments since the issuance of the staff report on December 23, 2010 (EBS/10/241). The additional information does not change the thrust of the staff appraisal.

\section{Recent indicators confirm that the} economy is stabilizing. Data to October suggest stabilizing of activity in the fourth quarter across a broad range of activities, including retail sales, construction, and industrial production, in line with staff expectations. This reflected the aftereffects on demand from the austerity measures. Inflation was marginally down in November (7.7 percent). Unemployment continued to decline, reflecting a declining participation rate rather than improvements in the labor market.

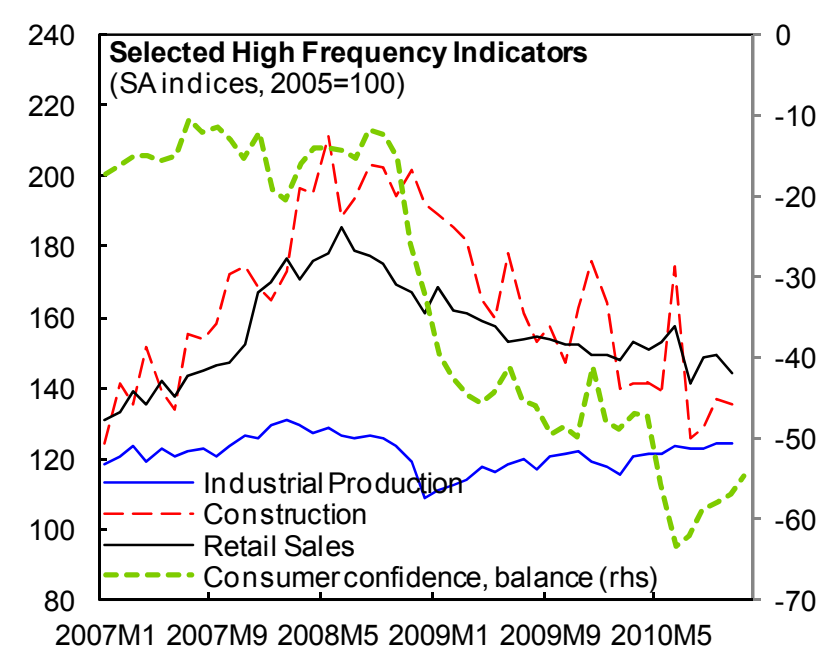

3. All prior actions for the sixth review have been met (Table 2, revised). Parliament approved the agreed 2011 budget, the unified wage reform legislation, and an amended version of the ordinance on credit contracts that improves the transparency of lending practices and protects consumer rights while safeguarding the stability of the financial system. The 24 percent VAT rate was also ratified by parliament in the context of the 2011 budget. The pension reform was promulgated at end-December and will come into force in 2011. Finally, arrears of the central government and social security were brought below 250 million lei, as agreed.

4. Two additional structural benchmarks due by end-2010 have been met. First, the deposit insurance legislation has been amended to ensure that neither members of the board nor employees of credit institutions can participate in the Board of the Deposit Guarantee Fund, with a view to avoiding conflict of interest. Second, a government ordinance amending the Fiscal 
Procedures Code was passed at end-December to give tax administration additional powers to better tackle taxation of high net wealth individuals.

5. The end-December NFA PC was met with a considerable margin. NFA totaled $€ 19.9$ billion, compared with the adjusted target of $€ 16.7$ billion. Preliminary data on the fiscal outturn for end-December also suggests that the end-December fiscal deficit target was likely met with a margin of some RON 1 billion ( 0.2 percent of GDP). 
Table 1. Romania: Quantitative Program Targets -- revised

\begin{tabular}{|c|c|c|c|c|c|c|c|c|c|c|c|c|c|}
\hline & \multirow{3}{*}{$\begin{array}{c}2008 \\
\text { Dec } \\
\text { Actual } \\
\end{array}$} & \multirow{3}{*}{$\begin{array}{l}\text { March } \\
\text { Actual }\end{array}$} & \multirow{3}{*}{$\begin{array}{r}2 \\
\text { June } \\
\text { Actual }\end{array}$} & \multirow{3}{*}{$\begin{array}{lr}\text { Sept } \\
\text { Actual } \\
\end{array}$} & \multirow{3}{*}{$\begin{array}{r}\text { Dec } \\
\text { Actual } \\
\end{array}$} & \multirow{3}{*}{$\begin{array}{l}\text { March } \\
\text { Actual } \\
\end{array}$} & \multirow{3}{*}{$\begin{array}{r}\text { June } \\
\text { Actual } \\
\end{array}$} & \multirow{2}{*}{\multicolumn{2}{|c|}{$\frac{2010}{\text { Sept }}$}} & \multirow{2}{*}{\multicolumn{2}{|c|}{ Dec }} & \multicolumn{2}{|c|}{2011} \\
\hline & & & & & & & & & & & & \multirow{2}{*}{\multicolumn{2}{|c|}{$\begin{array}{l}\text { January March } \\
\text { Perf. crit. Indicative }\end{array}$}} \\
\hline & & & & & & & & Prog. & Actual & Prog. & Actual & & \\
\hline \multicolumn{14}{|l|}{ I. Quantitative Performance Criteria } \\
\hline 1. Change in net foreign assets (mln euros) $1 / 2 /$ & 25,532 & $-3,500$ & $-5,119$ & $-4,566$ & $-4,874$ & 779 & -509 & $-2,350$ & -319 & $-3,950$ & -750 & 0 & 350 \\
\hline 2. Floor on general government overall balance ( $m$ ln lei) $3 / 4 / 5 /$ & $-24,655$ & $-8,300$ & $-14,456$ & $-25,563$ & $-36,101$ & $-8,422$ & $-18,015$ & 27,505 & 23,732 & $-34,650$ & $\ldots$ & & $-6,300$ \\
\hline 3. Stock in general government arrears (bn lei) & 1.06 & 1.41 & 1.55 & 1.4 & 1.50 & 1.76 & 1.8 & 0.81 & 1.57 & 0.48 & & & 0 \\
\hline 4. Ceiling on general government guarantees issued since start of program (face value, bn lei) & $\ldots$ & $\ldots$ & 0.02 & 0.8 & 2.2 & 4.6 & 5.5 & 12.0 & 6.5 & 12.0 & $\ldots$ & & 12.0 \\
\hline \multicolumn{14}{|l|}{ II. Continuous Performance Criterion } \\
\hline 5. Nonaccumulation of external debt arrears & 0 & 0 & 0 & 0 & 0 & 0 & 0 & 0 & 0 & 0 & $\ldots$ & & 0 \\
\hline \multicolumn{14}{|l|}{ III. Inflation Consultation } \\
\hline \multicolumn{14}{|l|}{ 6. 12-month rate of inflation in consumer prices } \\
\hline Outer band (upper limit) & $\ldots$ & $\ldots$ & 8.4 & 7.7 & 6.5 & 6.5 & 6.0 & 10.0 & $\ldots$ & 10.0 & $\ldots$ & & 9.0 \\
\hline Inner band (upper limit) & $\ldots$ & $\ldots$ & 7.4 & 6.7 & 5.5 & 5.5 & 5.0 & 9.0 & $\ldots$ & 9.0 & $\ldots$ & & 8.0 \\
\hline Actual/Center point & 6.3 & 6.7 & 5.9 & 4.8 & 4.7 & 4.2 & 4.4 & 8.0 & 7.8 & 8.0 & $\ldots$ & & 7.0 \\
\hline Inner band (lower limit) & $\ldots$ & $\ldots$ & 5.4 & 4.7 & 3.5 & 3.5 & 3.0 & 7.0 & $\ldots$ & 7.0 & $\ldots$ & & 6.0 \\
\hline Outer band (lower limit) & $\ldots$ & $\ldots$ & 4.4 & 3.7 & 2.5 & 2.5 & 2.0 & 6.0 & $\ldots$ & 6.0 & $\ldots$ & & 5.0 \\
\hline \multicolumn{14}{|l|}{ IV. Indicative Target } \\
\hline 7. General government current primary spending (excl. EU funds and social assistance, $\mathrm{mln}$ lei) $3 /$ & 92,327 & 22,149 & 43,238 & 63,878 & 85,637 & 32,749 & 66,124 & 100,000 & 98,721 & 131,500 & $\ldots$ & & 32,200 \\
\hline $\begin{array}{l}\text { 8. Operating balance (earnings before interest and tax) net of subsidies of } 10 \text { SOEs, } \\
\text { defined in TMU ( } \mathrm{mln} \text {. lei) } 3 /\end{array}$ & & & & & & $-1,081$ & $-2,333$ & $-3,000$ & $-3,801$ & $-4,000$ & $\ldots$ & & -750 \\
\hline \multicolumn{14}{|l|}{ Memorandum Item: } \\
\hline Revenue of general government, net of EU funds ( $\mathrm{mln}$. lei) $3 /$ & $\ldots$ & $\ldots$ & $\ldots$ & $\ldots$ & 151,508 & 36,355 & 74,669 & 114,700 & 116,091 & 157,950 & $\ldots$ & & 40,100 \\
\hline
\end{tabular}

1/ The December 2008 figure is a stock. The September and December 2010 program targets are adjusted for the shorffall in EC/World Bank disbursements.

2/ Performance criterion for January 2011 and indicative target for March 2011 are relative to December 2010 target.

3/ Cumulative figure during calendar year (e.g. March 2011 figure is cumulative from January 1, 2011).

of the revenue over-performance.

5/ The target for March 2011 can be adjusted with higher or lower capital spending as defined in TMU. 


\section{Prior actions}

1. Parliamentary approval of the agreed 2011 budget, including ratification of the 24 percent VAT rate

2. Ensuring central government and social security arrears at near zero at endNovember 2010

3. Approval of the unified public wage legislation

4. Enactment of the pension reform

5. Amending ordinance on credit contracts so that it improves transparency and protects consumer rights while safeguarding the stability of the financial system.

Quantitative performance criteria

1. Floor on net foreign assets

2. Floor on general government overall balance

3. Ceiling on general government guarantees

4. Ceiling on general government domestic arrears

5. Non-accumulation of external debt arrears

\section{Quantitative Indicative Target}

1. Ceiling on general government current primary spending

2. An indicative target on the operating balance of ten largest loss-making SOEs

\section{Inflation consultation band}

Inner band

Outer band

\section{Structural benchmarks}

1. Approval of reforms to mitigate fiscal risks from local governments

2. Reform of the DGF's funding regime through increase in bank's contribution rates and elimination of stand-by credit lines, and review of DGF governance arrangement

3 Parliamentary ratification of the fiscal measures approved by the government

4 Passage of framework and implementing legislation for the unified wage law

5 Reform tax administration methodology for high net wealth individuals

6 Parliamentary ratification of amendments to the bank resolution framework

7. Parliamentary approval of agreed 2011 budget

8. Amend deposit insurance legislation to ensure that neither members of the board nor employees of credit institutions participate in the DGF Board

9. First phase to integrate the accounting reporting system with the Treasury payment system
Met, parliamentary approval on December 22

Met

Met, parliamentary approval on December 20

Met, legislation published on December 20

Met, parliamentary approval on December 23

September, 2010

September, 2010

September, 2010

September, 2010

September, 2010

September, 2010

September, 2010

Missed

September, 2010

September, 2010

Met

Met

September 30, 2010

September 30, 2010

Met in June 2010

Met; the reform of the governance arrangement modified to end-December 2010 , amended by emergency ordinance on December 28

September 30, 2010

Partially met, VAT ratification reset as prior action

October 31, 2010

Not met, reset as prior action

November 30, 2010

Met after reset to December 31, 2010; emergency ordinance approved on December 23

December 1, 2010

Partially met

December 15, 2010

Reset as prior action

Met; amendment approved as emergency ordinance on December 28

March 31, 2011

Modified and reset for March 15, 2011

\section{Proposed structural benchmarks}

10. Amend legislation to allow the use of the deposit guarantee fund resources to facilitate bank restructuring, including purchase and assumption transactions 


\section{IMF Completes Sixth Review Under Stand-By Arrangement with Romania and Approves €904.8 Million Disbursement}

The Executive Board of the International Monetary Fund (IMF) today completed the sixth review of Romania's economic performance under a program supported by a 24-month StandBy Arrangement (SBA). The completion of the review enables the immediate disbursement of SDR 769 million (about $€ 904.8$ million or US $\$ 1.17$ billion), bringing total disbursements under the program to SDR 10.569 billion (about $€ 12.44$ billion or US $\$ 16.12$ billion).

In completing the review, the Executive Board also approved Romania's requests for a waiver of nonobservance of the end-December 2010 performance criterion on general government domestic arrears and for a waiver of applicability of the end-December 2010 performance criteria on the general government overall balance, the general government guarantees and for the target on inflation at end-December 2010.

The SBA was approved on May 4, 2009 (Press Release No 09/148) in the amount of SDR 11.443 billion (about $€ 13.46$ billion or US $\$ 17.45$ billion). The arrangement entails exceptional access to IMF resources, amounting to 1,111 percent of Romania's quota.

Following the Executive Board's discussion on Romania, Mr. John Lipsky, First Deputy Managing Director and Acting Chair, stated:

"Policy implementation under the Fund-supported arrangement has remained strong. However, progress on the elimination of domestic arrears has been slower than envisaged. The authorities have taken important structural measures, including pension and public wage reforms and the passage of a prudent 2011 budget.

"Romania is now on a clear path to meeting its short and medium-term fiscal goals. The current challenge is to fully implement the approved reforms and maintain tight control over expenditures to assure that the budget parameters are observed. In this respect, further efforts are crucial in the health care sector and in public enterprises to control spending pressures. Improving absorption of European Union structural funds should become a top government priority. Efforts to improve tax administration should continue. The initiation of labor and social safety net reforms will also help boost productivity and target limited budgetary resources to the

Washington, D.C. 20431 • Telephone 202-623-7100 • Fax 202-623-6772 • www.imf.org 
most vulnerable. Priority should be given to permanently resolving the issue of domestic arrears by way of improving payment discipline in the economy and increasing the credibility of the authorities' adjustment efforts.

"The authorities' monetary and financial sector policies have been appropriately prudent and proactive, helping preserve financial stability in the face of the global financial crisis. The jump in inflation due to the recent value added tax increase is temporary, but continued caution is nevertheless needed in gauging the timing and remaining room for further monetary easing. The banking system remains liquid and well-capitalized, but continued vigilance in financial sector supervision is crucial to assure financial sector resilience against increasing non-performing loans and the unsettled regional situation." 


\section{Statement by Age Bakker, Executive Director for Romania and Mihai Nicolae Tanasescu, Senior Advisor to the Executive Director January 7, 2011}

My Romanian authorities would like to express their appreciation for the useful discussions held in Bucharest in October. The staff report provides a balanced assessment of the program implementation and the commitments of my authorities.

The far-reaching and comprehensive program supported by the Fund, the European Union, and the World Bank has continued to play an important role in stabilizing the Romanian economy, reversing imbalances, rebuilding confidence of international financial markets, and setting the stage for future sustainable economic growth.

Romania is on track with the implementation of quantitative targets. All end-September performance criteria and indicative targets have been met, with the exception of the ceiling on general government domestic arrears, for which my authorities have requested a waiver. My authorities are committed to implementing further measures to reduce arrears, and to keep those of the central government near zero for the remainder of the program.

\section{Economic developments}

After turning positive in the second quarter, economic growth fell by 0.7 percent in the third quarter, reflecting mainly the effect of fiscal adjustment on domestic demand. At the beginning of July, the government introduced austerity measures, including an increase in the VAT rate by 5 percentage points, which delayed the recovery. In this context, growth is expected to reach -1.9 percent for 2010, but with consumer confidence and economic sentiment gradually improving and export-oriented industry continuing to grow, it is expected that growth will turn positive in the last quarter of 2010 or early in 2011 . For 2011 , growth is expected to be 1.5 percent, and to accelerate above 3 percent in 20122015 .

The inflation rate is expected to peak in the coming months, due to the recent increase in VAT, but so far the effects have been less than expected. However, upside risks to inflation are related to food price pressures from higher world prices, the effects of recent flooding on domestic agricultural production, and further adjustment in administrated prices. Barring significant second-round increases, the price-level effects should peter out after mid-2011, allowing attainment of the end-2011 target of 3 percent plus/minus 1 percentage point.

The current account deficit improved significantly from 13.5 percent of GDP in 2007 to an annualized rate of 5 percent of GDP by September 2010. However, a larger services deficit and weaker remittances are limiting further adjustment in the current account, which is projected to remain at a similar, sustainable level in the years ahead. 
Financial market stress has eased further in the last months, and the CDS spread for sovereign debt has narrowed, leaving it well below several other EU countries, including countries from the euro-area periphery.

\section{Fiscal policy and structural reforms}

The fiscal package implemented in July, yielding about 5 percent of GDP, produced the targeted adjustment. As a result, the end-September deficit and current spending targets were met by a significant margin, and this has created the right conditions to meet the deficit target for the year as a whole. The 2011 budget has been approved, and the authorities are fully committed to reducing the deficit to 4.4 percent of GDP from 6.8 percent of GDP in 2010.

On the revenue side, tax policies will remain largely unchanged, including the VAT rate, which will be kept at 24 percent. On the spending side, the government will keep the wage bill within the agreed limit of RON 39 billion, and will take additional measures to secure the 2011 deficit target, including further health sector reforms, reducing subsidies, and continuing public employment reductions by, inter alia, maintaining the policy of replacing only 1 of 7 departing workers. At the same time, the government will broaden the base of health contributions, improve revenues and control expenditures, and it will continue with the much needed comprehensive reform of the education system, which should improve the quality of instruction while generating additional savings as a result of rationalization of school network and teacher workload. These measures will help consolidate the fiscal stance and create a path for sustainable economic growth, aiming to bring the deficit down to 3 percent of GDP by 2012 .

Domestic payment arrears in local governments continue to pose a challenge, but some of the actions implemented, including the repayment of about 2 billion lei $(0.4$ percent of GDP), have demonstrated the government's commitment to addressing this structural problem. At the same time, the government will allocate the necessary funds in 20102011 to prevent accumulation of further arrears and will ensure that central government and social security sector arrears remain near zero for the remainder of the program. Furthermore, local governments' arrears should start a downward trend during 2011, when amendments to the local public finance law will require repayment of arrears.

On the structural side, the government has made significant progress, and key structural reforms have been recently approved by the Parliament. In this context, both the pension law and the unified wage law, which were approved at the end of December, will generate fiscal savings in future years and will improve efficiency of the remaining expenditures. Moreover, the authorities continued to make efforts to improve tax collection and administration and to fight tax evasion.

The authorities have also made efforts on labor market and social reforms. A reform of social benefits, which has already been submitted to Parliament, will improve the efficiency of protecting the poorest and most vulnerable, and will consolidate the 
guaranteed minimum income, heating benefits and family allowance into one new scheme.

Major efforts will be implemented to improve the performance of public enterprises and to reduce their losses through widening the revenue base, strengthening controls, and reforming legislation to increase transparency of procurement. The government will continue the process of winding-up or privatizing state owned enterprises.

One of the main challenges of structural reform is stepping up efforts to improve the absorption of EU structural funds for investment. To address this, the government will implement several measures including restructuring key investment units, streamlining the portfolio of investment projects and focusing on those projects financed by EU funds, and encouraging greater private sector participation in investment projects.

\section{Monetary and financial sector policies}

The monetary authorities responded well to falling activity, and the Central Bank has taken crucial measures to bring down inflation levels. However, after July's government decision to increase the VAT, the Central Bank has left its easing cycle on hold keeping its key policy rate unchanged. While the one-off nature of the VAT-induced price increase does not warrant a monetary policy response, the authorities believe that increased vigilance is needed to keep inflation expectations in check and stave off possible second-round inflationary effects.

The Romanian financial system so far has weathered well the impact of the economic contraction. Even though the banking system registered losses, capitalization ratios stayed high due to timely injections of capital by banks. All parent banks of the nine largest foreign banks have complied with their commitment to maintain exposures under the European Bank Coordination Initiative and in aggregate ended November at 97 percent.

Romania has made further progress towards strengthening the financial sector, and is committed to consolidate the safety net to deal with financial distress. In this context, Parliament has ratified the amendments to the banking law that enable the special administrator to promptly implement a broad range of restructuring measures. At the same time, the Central Bank has taken steps to strengthen the funding and governance of the Deposit Guarantee Fund. Parliament has also clarified that the NBR will remain the sole agency with authority to suspend a bank's activity. However, additional changes will be redrafted at the beginning of 2011, in line with Fund advice.

\section{A follow-up arrangement}

The economic situation remains challenging, and risks both to growth and inflation are large, but balanced. The ongoing turbulence in the Euro-area periphery could still spill over into Eastern Europe, raising risk premia and affecting capital flows to Romania. With a major macroeconomic adjustment firmly in place, my authorities are now 
committed to accelerate structural reforms, while consolidating macroeconomic stability, in order to further shore up confidence of the international financial markets and restore economic growth. To help them maintain the reform momentum and to provide additional security against unforeseen shocks, my authorities have requested negotiations on a follow-up arrangement with the Fund. This arrangement, which would be treated as precautionary, would build on the considerable progress achieved over the past two years and set the stage for strong and sustainable economic development while maintaining external and internal stability. 